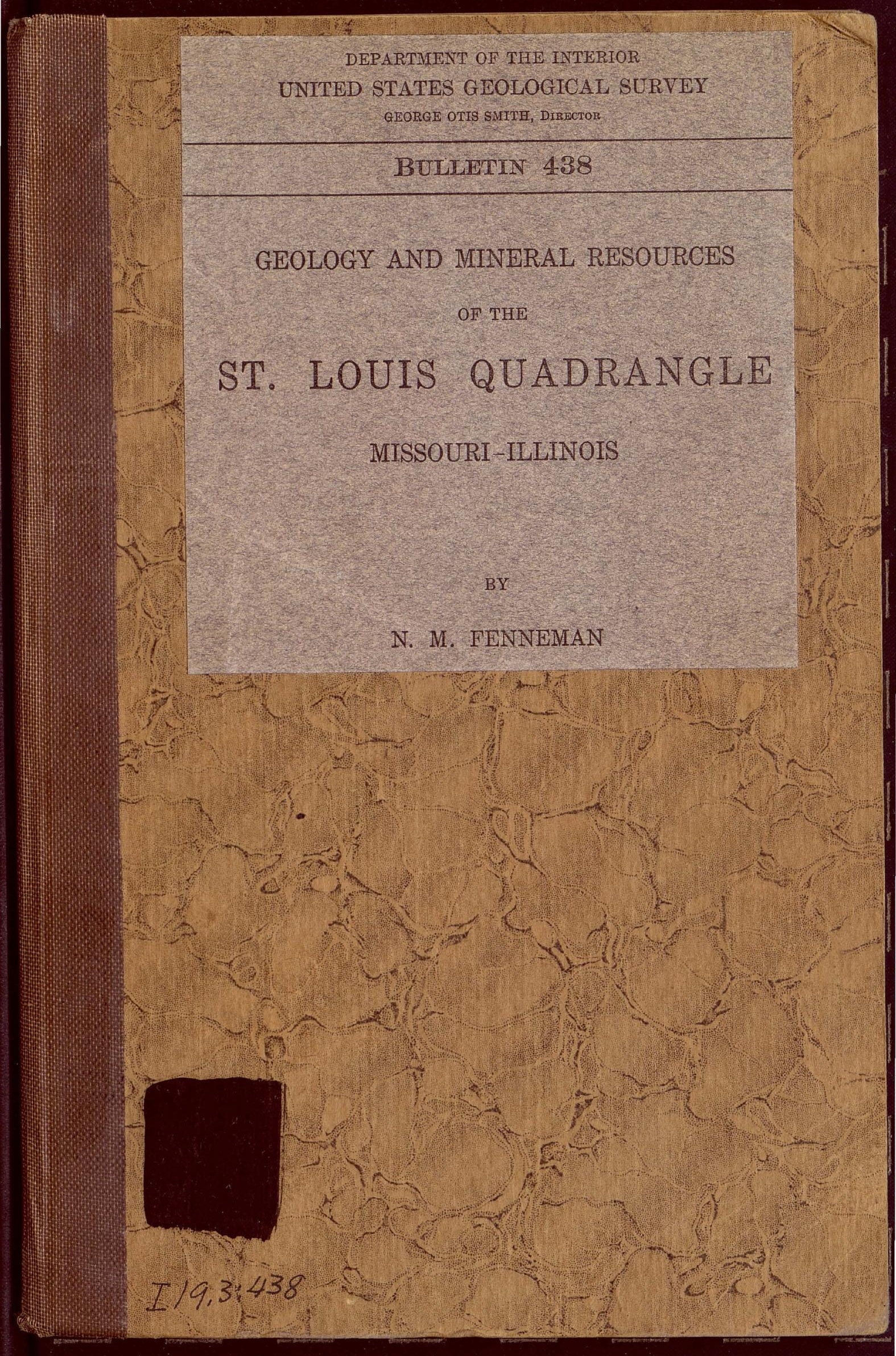




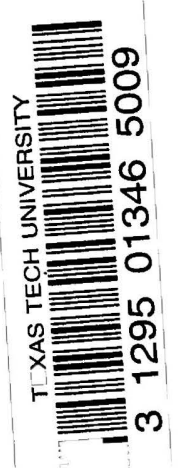

TEXAS TECH LBI ARY DOQUIEATS

DATE DUE

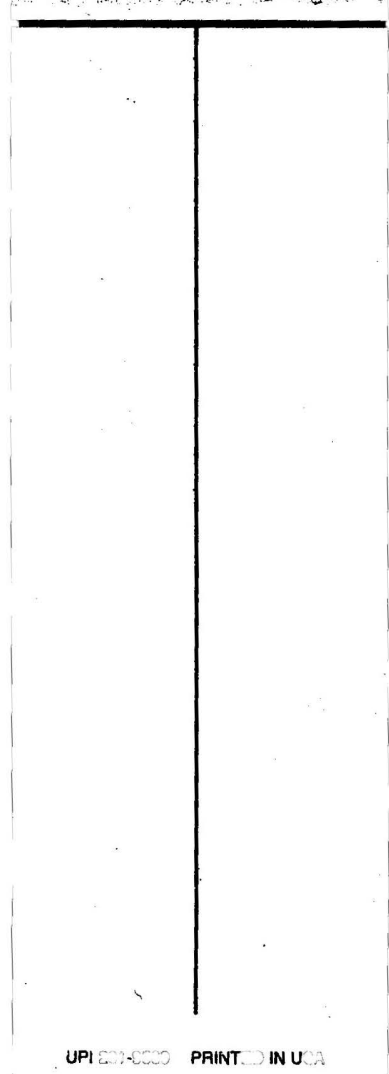


AMG 0706

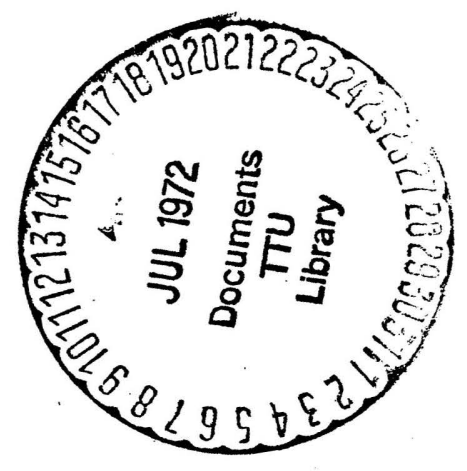



DEPARTMENT OF THE INTERIOR

UNITED STATES GEOLOGICAL SURVEY

GEORGE OTIS SMITH, DIRECTOR

BULLETIN 438

GEOLOGY AND MINERAL RESOURCES

OF THE

ST. LOUIS QUADRANGLE

MISSOURI-ILLINOIS

BY

N. M. FENNEMAN

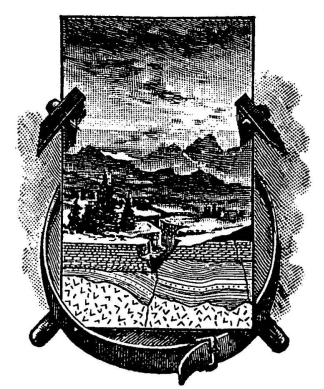

LIDKARY

TEXAS TECHNOLOGICAL COLLEGE LUBBOCK, TEXAS

WASHIN GTON

GOVERNMENT PRINTING OFEICE

1911 



\section{CONTENTS.}

Introduction Page.

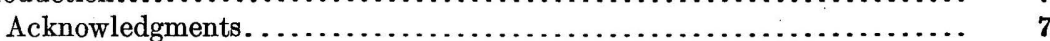

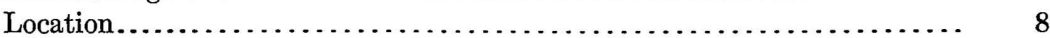

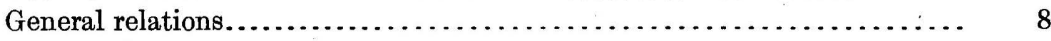

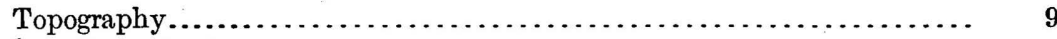

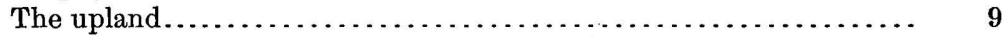

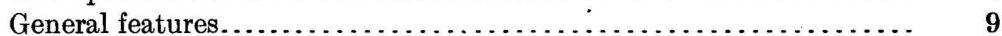

Small valleys....................................... 9

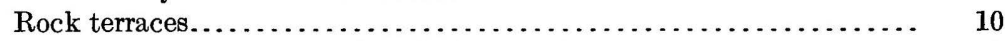

Relation of topography and underlying rocks.............. 10

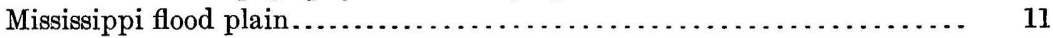

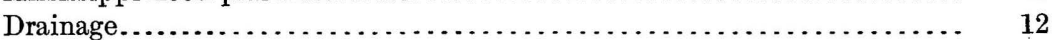

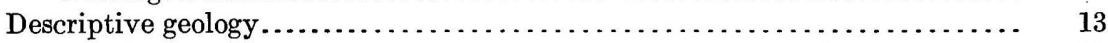

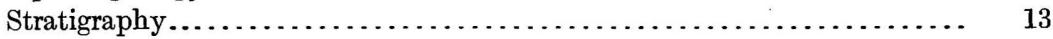

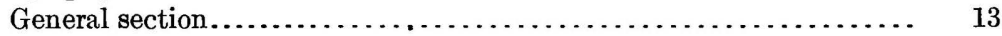

Detailed well sections................................... 14

Well near Monks Mound............................. 14

Well at the insane asylum............................ 15

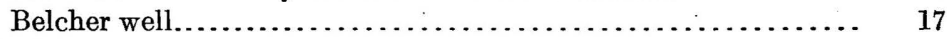

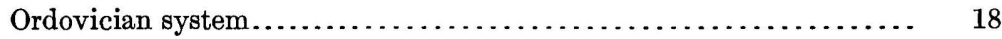

St. Peter sandstone. . . . . . . . . . . . . . . . . . . . . . 18

Formations above the St. Peter sandstone............... 18

Carboniferous system................................ $\quad 19$

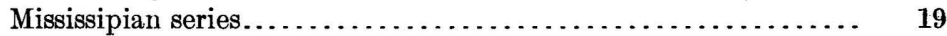

Kinderhook formation......................... 19

Osage group (Burlington and Keokuk limestones)......... 20

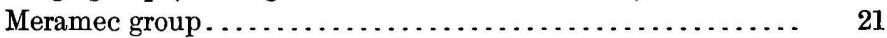

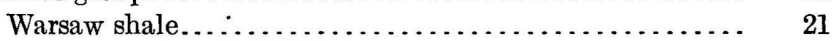

Spergen limestone. . . . . . . . . . . . . . . . . . . 22

St. Louis limestone. . . . . . . . . . . . . . . . . . $\quad 23$

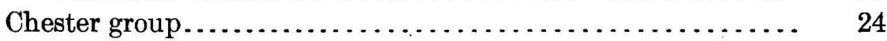

Pennsylvanian series ("Coal Measures") ................ 25

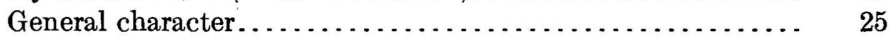

Cheltenham fire clay. . . . . . . . . . . . . . . . . . . . 28

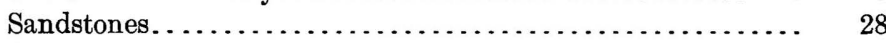

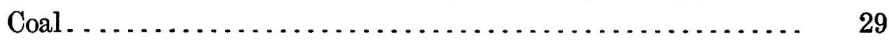

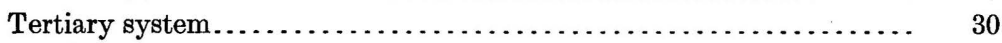

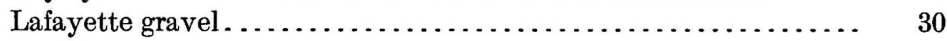

Composition...................................... 30

Topographic position............................. 31

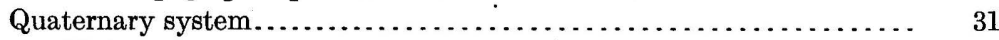

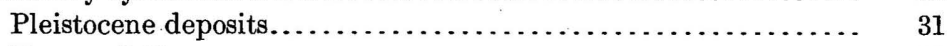

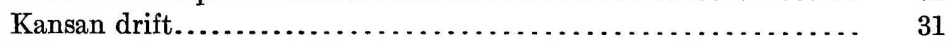

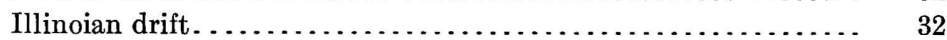

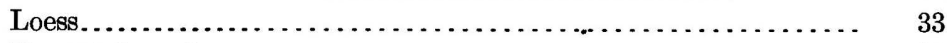

Recent deposits................................... 34

Alluvium of the flood plain....................... 34

Terraces..................................... 34 
Descriptive geology-Continued. Page.

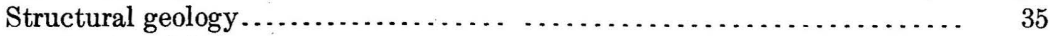

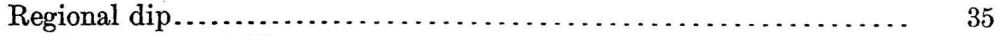

Local transverse folds.............................. 36

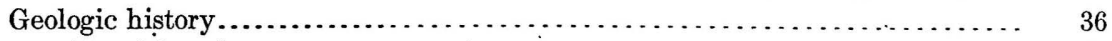

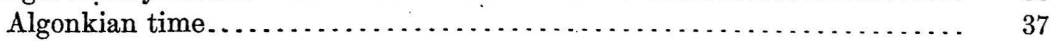

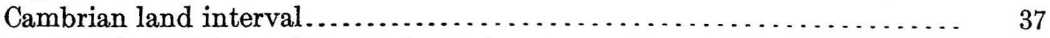

Cambro-Ordovician sedimentation . . . . . . . . . . . . . . . . . . $\quad 37$

Formation of magnesian limestone................ $\quad 37$

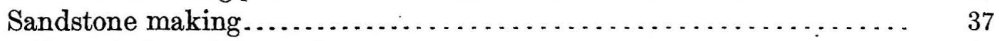

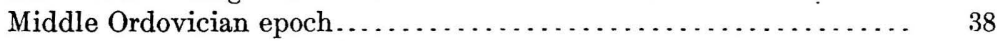

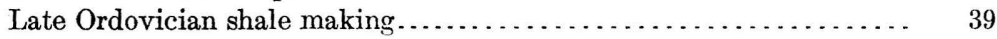

Silurian-Devonian land period . . . . . . . . . . . . . . . . . . . . 39

Carboniferous sedimentation. . . . . . . . . . . . . . . . . . . . . . 40

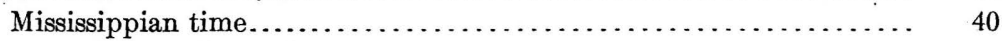

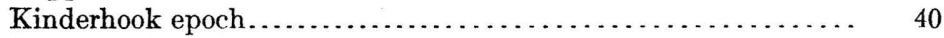

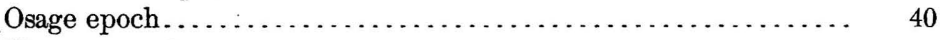

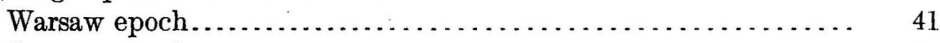

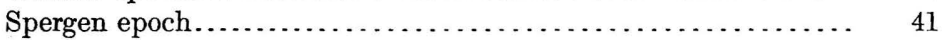

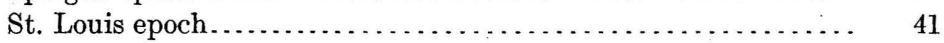

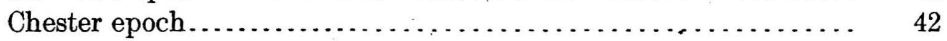

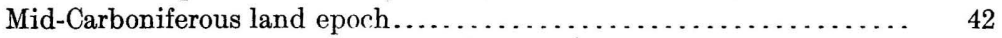

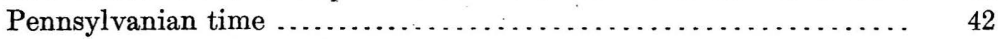

Post-Carboniferous uplift and peneplain...................... 43

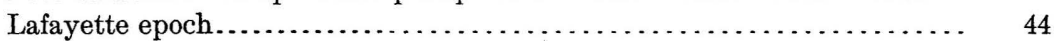

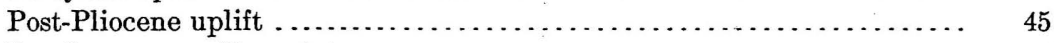

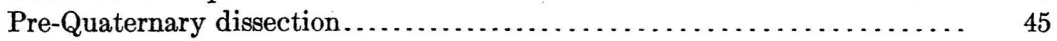

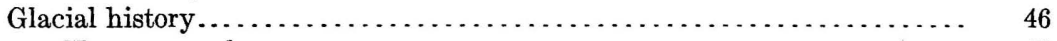

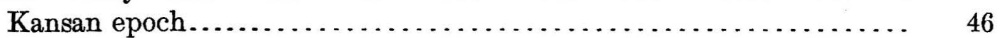

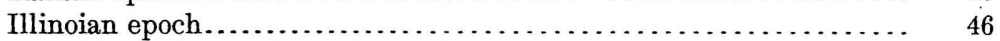

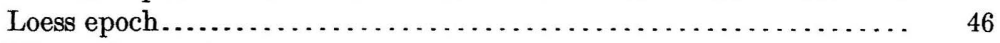

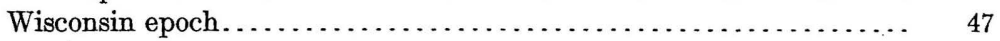

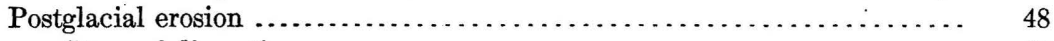

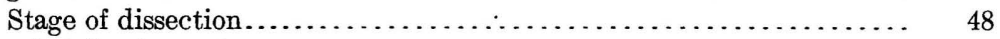

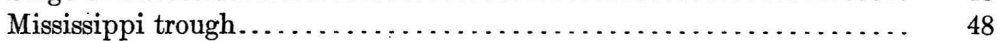

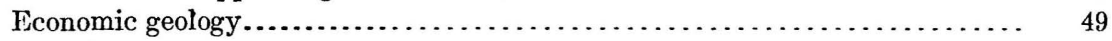

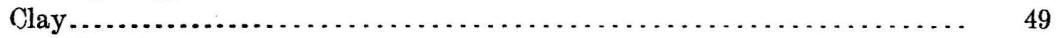

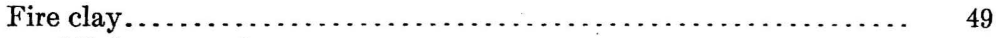

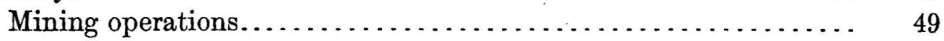

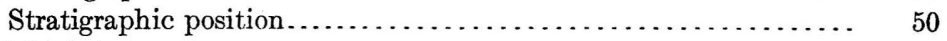

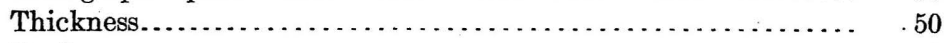

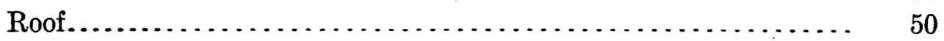

Floor....................................... 50

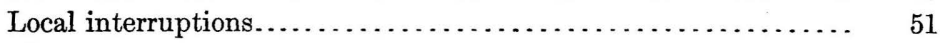

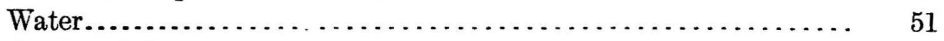

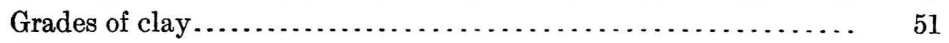

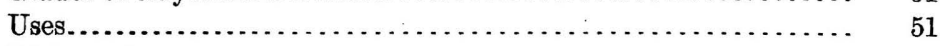

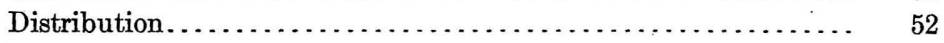

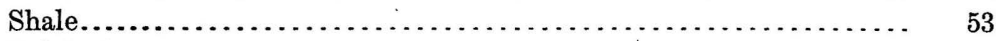

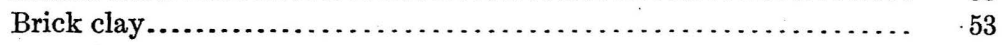

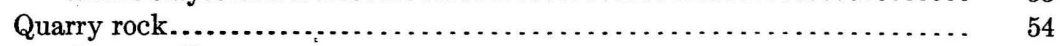

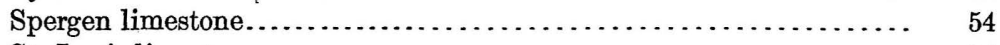

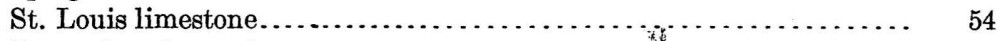

Pennsylvanian series................................... 54 
Economic geology-Continued. Page.

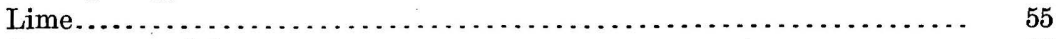

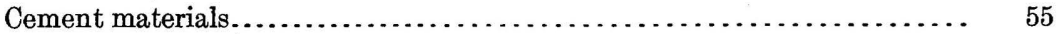

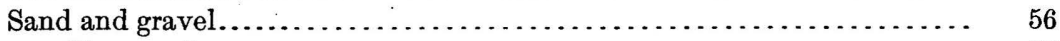

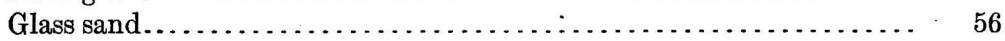

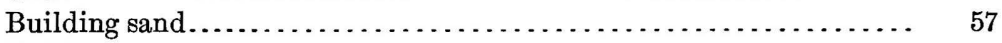

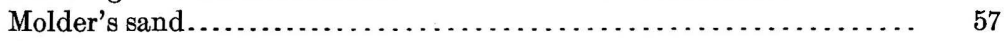

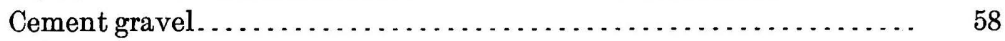

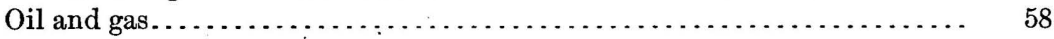

Area in St. Louis.......................................... 59

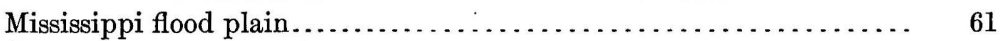

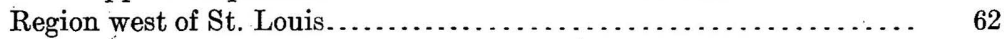

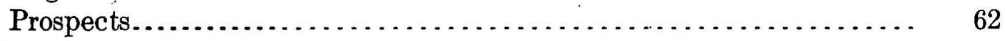

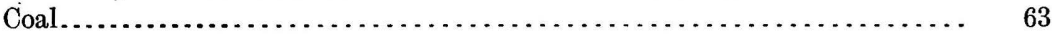

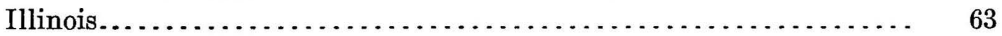

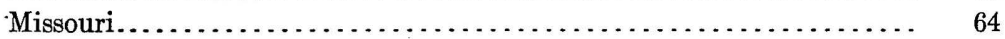

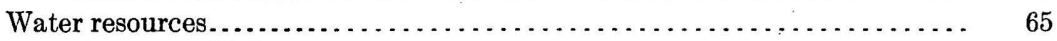

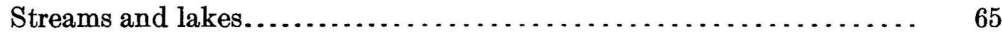

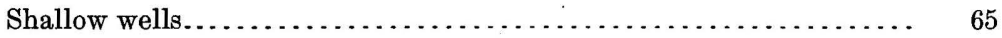

Wells on the Mississippi flood plain. ................. 65

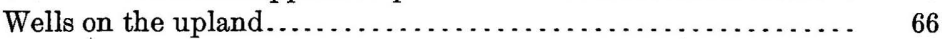

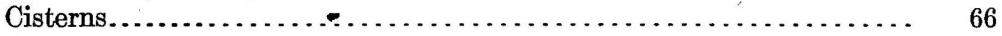

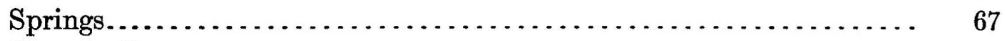

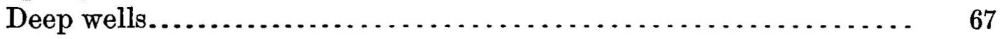

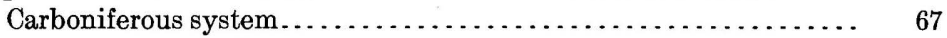

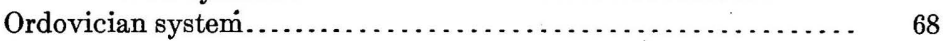

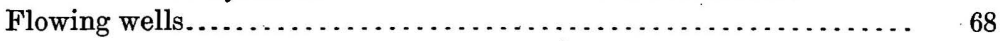

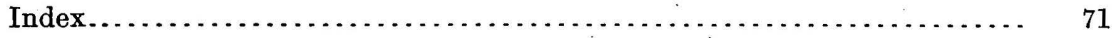

\section{ILLUSTRATIONS.}

Plate I. Geologic map of St. Louis quadrangle................... In pocket.

II. Sink holes south of Stolle, Ill............................ 10

III. $A$, St. Peter sandstone, Pacific, Mo.; $B$, Cross-bedding in Spergen limestone, Meramec Highlands, Mo................... 18

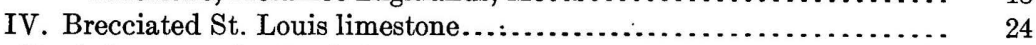

V. $A$, Loess on St. Louis limestone, one-half mile south of Stolle, Ill.; $B$, Lafayette gravel on Carboniferous shale, northwest of Glencoe,

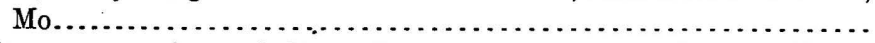

VI. Structure sections: $A$, From Crystal City, Mo., to point near Peters station, Ill.; $B$, From Pacific, Mo., to Monks Mound, Ill ......... 36

Frgure 1. Index map showing location of St. Louis quadrangle.......... 8 



\section{GEOLOGY AND MINERAL RESOURCES OF THE ST. LOUIS QUADRANGLE, MISSOURI-ILLINOIS.}

By $\mathrm{N}$ M. Fenneman.

INTRODUCTION.

ACKNOWIEDGMENTS.

The field work which forms the basis of this report was done in the summer of 1906 under the joint auspices of the United States Geological Survey and the State Geological Survey of Illinois. A report on the physiography of the region has been submitted to the Illinois Survey and published as Bulletin 12. The writer of this report was aided in the field by J. C. Jones, of the Illinois Survey. The geologic map is, in the main, his work. Valuable counsel and assistance were received from Profs. R. D. Salisbury and Stuart Weller, of the University of Chicago, acting as members of the Illinois Survey. Maps and data of considerable value were received from the Mississippi River Commission and the United States engineer in charge of Mississippi River.

The interest taken in the work by many citizens of St. Louis gave very material assistance in collecting important data not directly obtainable in the field. Mr. Arthur Thacher is especially to be thanked for assistance of this character. Generous help was also received from Mr. H. A. Wheeler, whose former work on the Missouri Geological Survey gave him special familiarity with the region; from Mr. George More, whose experience in bridge building put him in possession of valuable data regarding the formations beneath the channels of Mississippi and Missouri rivers; from Mr. William B. Potter, manager of the St. Louis Sampling and Testing Works, who has made many analyses of the water from this vicinity; and from Mr. Charles W. Francis, assistant health commissioner, who furnished data concerning the wells of St. Louis. The information and assistance received from numerous well drillers and managers or other officers of clay mines and factories, quarries, etc., was so varied and abundant as to preclude the mention of individual names.

The writer was at different times accompanied in the field by Dr. W J McGee, whose many suggestions were of much value. A 
similar acknowledgment is due to Mr. Gerard Fowke, who is familiar with the field and who accompanied the writer for several days. The mapping of the isolated patches of Illinoian drift west of the Mississippi rests in part on the work of Prof. J. A. Drushell, of the Teachers College of St. Louis.

\section{LOCATION.}

The area considered in this report is known as the St. Louis quadrangle. It is a rectangle 31 miles long from east to west and $17 \frac{1}{4}$ miles wide, with an area of about 535 square miles. The entire area lies south of Missouri River, which touches its extreme northwest corner. The city of St. Louis is near the center of the area, and the Mississippi divides it into two nearly equal parts. (See fig. 1.)

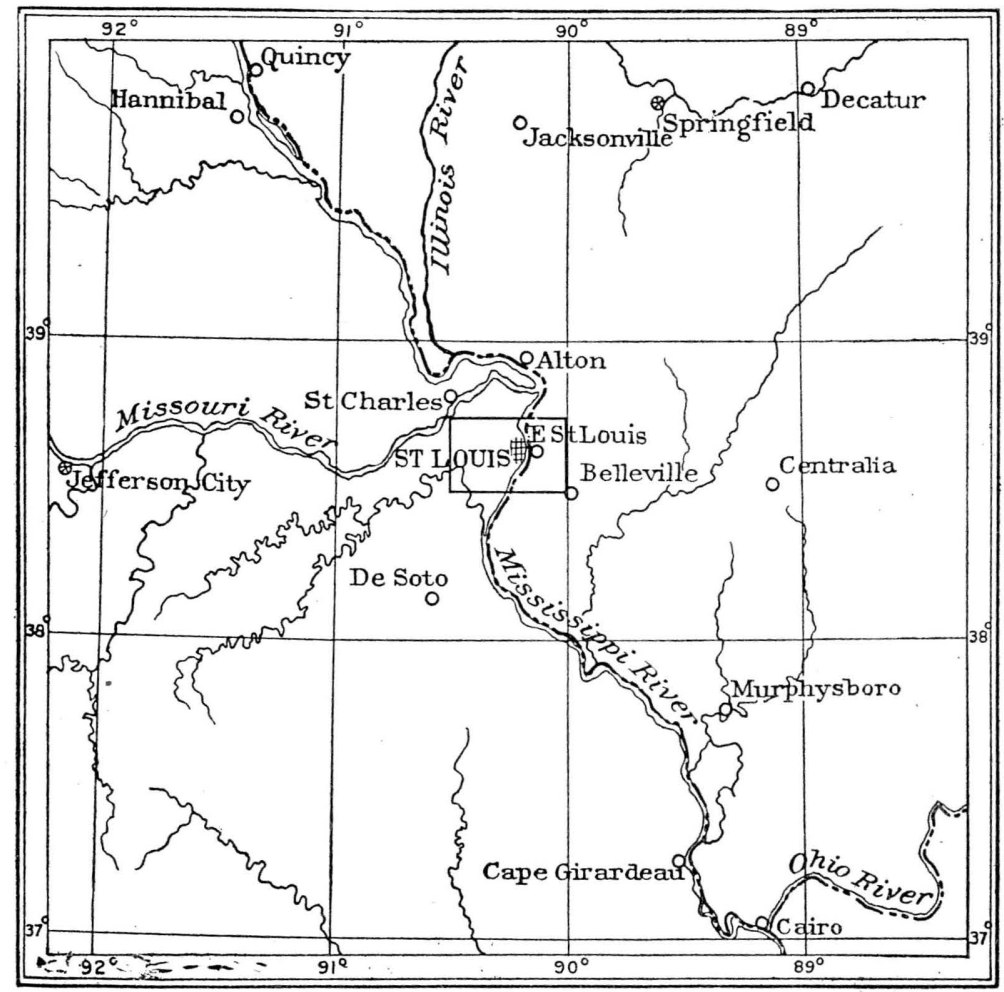

FigURE 1.-Index map showing location of St. Louis quadrangle.

GENERAL RELATIONS.

With reference to larger geologic features this area lies at the northeast base of the Ozark structural dome, between that dome and the synclinal basin of central Illinois. The general dip of the strata within the area is therefore to the north and east. Within the Ozark Plateau erosion has laid bare rocks of Cambro-Ordovician age; in the St. Francis Mountains, from 60 to 100 miles south of St. Louis, con- 
siderable areas of pre-Cambrian rocks are exposed. In the shallow synclinal basin of Illinois even the higher Pennsylvanian coal measures have been preserved from erosion. In passing eastward and northeastward from the St. Francis Mountains the outcrops of the several Paleozoic formations are crossed.

The St. Louis quadrangle lies just outside of the glaciated area, in a reentrant angle of its margin. To the south or southeast of St. Louis the margin of the glaciated area is the edge of the Illinoian drift sheet and follows in a general way the east bluff of Mississippi River. To the west the drift sheet of the Kansan glacial epoch appears, its margin following roughly the course of the Missouri.

\section{TOPOGRAPHY.}

The major elements of the topography are (1) the remains of a gently sloping upland from 550 to 700 feet above the sea, now interrupted by small valleys to such an extent that the whole surface is gently rolling; (2) the Mississippi flood plain, about 150 feet below the upland, which crosses the area from north to south, varying in width from 3 to 10 miles and in most places separated from the upland on either side by abrupt bluffs.

THE UPLAND.

GENERAL FEATURES:

The upland, though dissected and now represented only by remnants, most of which are mere ridges, is strikingly noticeable from any elevated position. As viewed from one of the major ridges, the sky line is almost perfectly horizontal. Only at long intervals may a gentle upward curving be noted, such as that representing the broad but slight elevation in the vicinity of Stratmann or the similar rise 2 miles farther north. Perhaps the most distinct of such features is 2 miles northwest of Ballwin (a short distance west of the St. Louis quadrangle), where a hill, less than half a mile wide at the base, rises at least 50 feet above the distinctly horizontal upland, which at that place is approximately 700 feet high.

The altitude of the upland 20 miles west of St. Louis on the divide between Missouri River on the north and the Meramec on the south, is about 750 feet. Its remnants in and near St. Louis are not above 550 feet high. Between these points there is a gradual and fairly uniform eastward slope.

East of Mississippi River the upland is even better shown than on the west side, its remnants being larger, and many of the valleys narrower and more sharply outlined. The continued downward slope to the east is, however, less distinct, being complicated by various other factors, among which are the added elevations due to the Illinoian drift sheet and the exaggerated easterly slope due to the extraordinary thickness of the loess on the bluffs. 
SMALI VALIEYS.

Inasmuch as the upland is everywhere covered with loess to a depth of 10 to 50 feet, the smaller and younger valleys are generally confined to that material. The characteristic cross section of those which are being cut under present conditions shows convex lateral slopes, the steepness increasing as the axis is approached. The steepness of the lateral slopes varies, of course, with the fall and cutting power of the stream and is greatest near the bluffs, but upward convexity of valley sides is the rule in these young valleys, whether gentle or steep.

The characteristic cross section of young valleys in the loess may be modified where gullying or excessive surface wash affects the sides. Under such conditions, which may be incident to cultivation, the excessive waste from the sides has accumulated below, giving compound curves to the otherwise upwardly convex side slopes. Valleys of somewhat greater size and age, such as those of the several branches of the River Des Peres, have lateral slopes of compound curves, being steeper at intermediate heights than near the streams. Still larger valleys, such as those of the lower Des Peres, have distinct flood plains.

\section{ROCK TERRACES,}

Here and there rock terraces border the larger valleys. The most conspicuous is at the foot of the east bluff of the Missouri, north of Creve Cœur Lake, opposite St. Charles. Here, for several miles north and south of Bonfils station, is a fine terrace about 40 feet above the flood plain. A quarry opened near its outer edge shows that it consists of St. Louis limestone and not of alluvium, as might be inferred from its position. The steep backward (easterly) slope from its outer edge toward the main bluff is due entirely to the thickness of the loess, which has here accumulated on the outer edge of the terrace, as it has elsewhere on the margin of the upland; that is, at the summit of the main bluff. Minor rock terraces appear on the east side of the Mississippi and on the south side of the Meramec west of Valley Park.

\section{RELATION OF TOPOGRAPHY AND UNDERLYING ROCKS.}

The topography of this region reflects to a striking degree the character of the underlying rock In places where that rock is limestone there is an extraordinary development of sink holes and subsurface drainage. These sink holes are numerous near the southern margin of the quadrangle, near the Mississippi bluff, as is well shown on the map (Pl. I, in pocket). (See also Pl. II, opposite.) Large areas in the city of St. Louis furnish abundant and striking examples, and in parts of the city similar holes have been filled. Sink holes do not occur where the limestone is covered by even a few feet of shale, and are consequently absent from that part of the area where the 


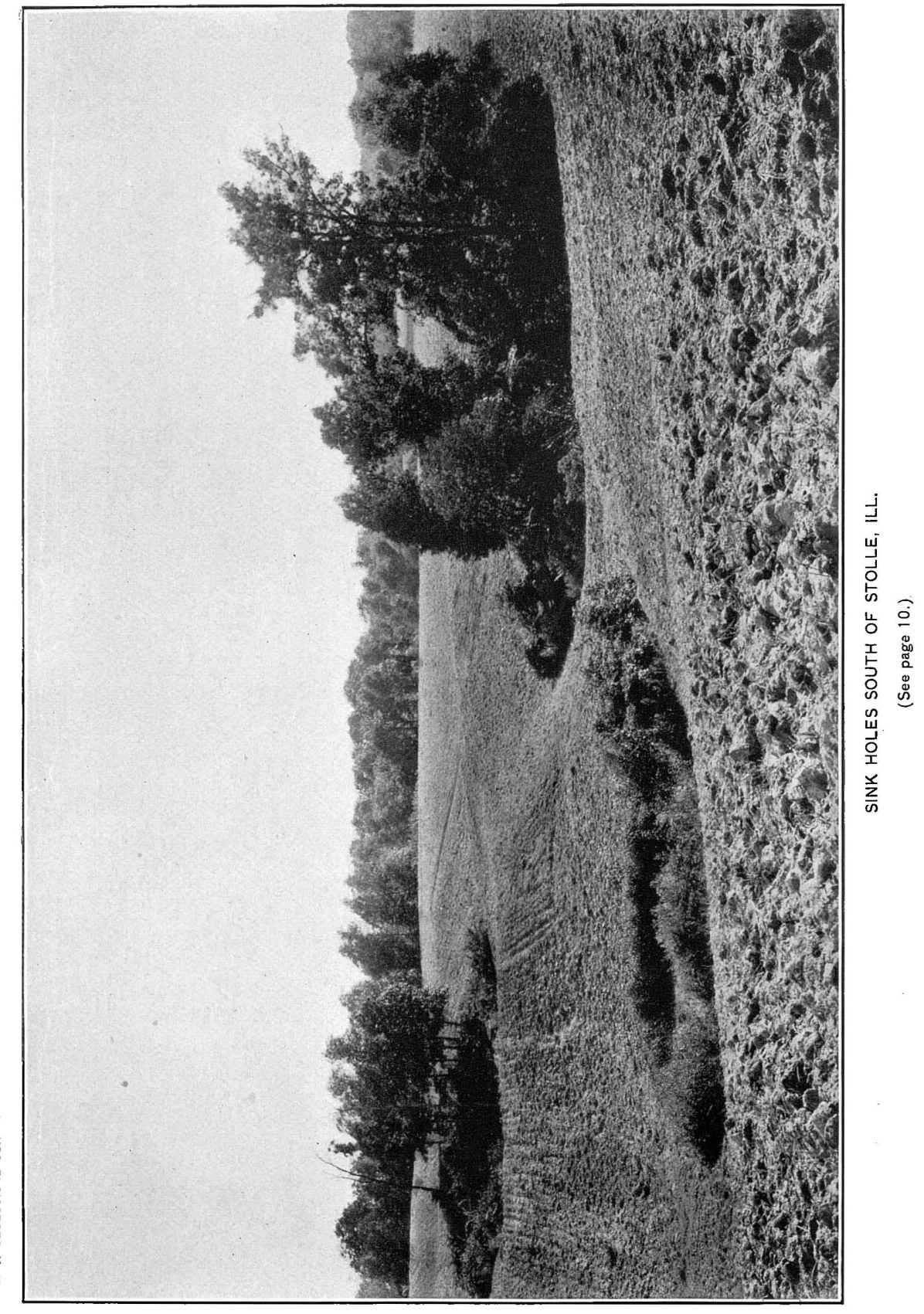



Pennsylvanian rocks are present. (See geologic map, Pl. I.) On these rocks, which consist largely of shale, the larger valleys (cut in the bedrock and not confined to the loess) are characterized by broad and gentle curves.

Where the topography is not completely dominated by a thick loess cover, with its characteristic valleys, it is frequently possible to judge of the underlying formation with considerable accuracy by the surface forms alone. This fact is strikingly illustrated on almost all sides of the great fire-clay district of Cheltenham, south of Forest Park, St. Louis. This district is essentially coextensive with the "Coal Measures," on which no sink holes exist. It is surrounded by a limestone area that is in most parts closely perforated with such holes, which are crowded close up to the margin of the Pennsylvanian area.

\section{MISSISSIPPI FLOOD PLAIN.}

Across the center of the quadrangle stretches the Mississippi flood plain, having a width varying from 3 to 10 miles. The surface of this plain declines slightly to the south with the grade of the river, whose fall is about 6 inches to the mile from the mouth of the Missouri to that of the Ohio. At the Eads Bridge, St. Louis, zero of the gage is taken at 380.23 feet above mean sea level. At Jefferson Barracks, which is 10.7 miles to the south, zero is 377.94 feet above sea level. The corresponding zero at the Chain of Rocks, 10.2 miles north of the Eads Bridge, is 384.31 feet. The fall of the river near St. Louis is therefore about $3 \frac{2}{3}$ feet to the mile, and the corresponding southward slope of the flood plain is about twice as great.

The greater part of the flood plain has an elevation between 400 and 420 feet, the latter height being exceeded only in the immediate vicinity of the bluffs and on a few isolated mounds. The surface of the flood plain, though containing many flat tracts, is far from being uniformly flat. A detailed map, giving contours at 5 -foot intervals, shows that the plain is in a large way ribbed or fluted with broad, low ridges and intervening slashes. There may be as many as ten such alternations of level within a mile, though the average width of ridges and swales is a considerable fraction of a mile. The prevailing though by no means uniform trend of these features is roughly parallel to the river at its nearest point or to a former channel now represented by an oxbow lake. Many of the swales or slashes are so low as to be swampy, and on the intervening higher grounds are fertile farms, which would be very valuable except for the liability to overflow. Near the Illinois bluff the level of the plain is higher, and there is a perceptible slope away from the bluff. Farms on this portion of the plain have extreme fertility.

Floods in historic times have not been known to rise higher than 421.63 feet above mean sea level. As this height has been observed 
but once (1844) and the next highest flood (1903) fell fully 3 feet short of it, the 420 -foot contour line may, for practical purposes, be taken as the approximate limit of.floods. This leaves, on the eastern margin of the flood plain, north of Edgemont, a strip not subject to overflow. The width of this strip, whose level has been raised by outwash of loess from the bluffs, is irregular, but averages a mile.

About 7 miles northeast of the Eads Bridge is a group of mounds, in part natural, though the highest of all, known as Monks or Cahokia Mound, is in part artificial. These elevations vary in height from a few feet to more than 100 feet and in diameter from a few rods to nearly 1,000 feet. They are composed of alluvium, and are in the main remnants of a former valley filling. Wherever observed, the material is fine sand or loam, similar to that which covers the flood plain. It may be in part a redeposited loess. To a height of 35 feet above its base the material of Monks Mound shows assortment and stratification, which is evidently natural. Above that height it affords no structural evidence bearing on the question whether it is of natural or artificial origin; but the form plainly indicates the work of man, and not of geologic processes. It is highly probable that the mound in its natural condition was much lower and broader than at present, and was of rounded, almost drumloidal form, similar to the smaller ones of the group which now surround it. By cutting down its margin to the level of the surrounding plain its builders obtained material to raise the mound to perhaps two or three times its former height without making excavations beneath the level of the plain and without carrying material from the bluffs, $2 \frac{1}{2}$ miles distant. There is no evidence that material was obtained by either of these latter means.

Of the surrounding group of mounds those of conspicuous height and abrupt slopes are doubtless of the same composite origin as Monks Mound. The smaller ones, of gentle slope and oval form, no doubt represent the original condition of all.

DRAINAGE.

The drainage of the entire region flows, for the most part, through short streams directly into the Mississippi. A portion of the territory, however, drains northwestward to the Missouri, whose course is here northeastward toward Bellefontaine and Alton. The divide between these two systems is not a striking topographic feature and only at isolated points does it rise above the general upland level. Such isolated eminences are the low and poorly defined swell on which Stratmann stands and a similar rise several miles farther north.

An area equal to that drained by the Missouri lies in the basin of Meramec River, which flows southeastward, joining the Mississippi about 15 miles south of St. Louis. The divide between the Meramec and Missouri. systems is marked by the high ground near Altheim. 
The small streams that enter the Mississippi from the east are obliged to traverse the broad flood plain, and in these portions of their courses may have vague and ill-defined valleys. From the loess-covered bluffs and uplands they bring down much silt, which is spread out at the foot of the bluff, often clogging the streams and causing their courses to change. Schoenberger Creek, emerging from the bluff at French Village, is said to flow either north or south in the same channel, according to the stage of the water in the basin of Cahokia Creek, on the north, and of Prairie du Pont Creek, on the south. ${ }^{a}$

\section{DESCRIPTIVE GEOLOGY.}

STRATIGRAPHY.

GENERAL SECTION.

The indurated strata exposed in this area are all of Carboniferous age. Natural exposures of these beds are found only in the steeper bluffs and here and there in a gully. Mesozoic rocks are absent. The Tertiary is represented by a few small patches of gravel believed to be of Lafayette age. These indurated rocks and gravel are almost everywhere covered by Pleistocene deposits. East of Mississippi River these younger deposits include bowlder clay of the Illinoian glacial epoch. Probably bowlder clay of both Illinoian and Kansan age is present in small quantities on the west side of the river. Whatever till may exist is covered by loess. Along Mississippi River the Mississippian strata are overlain by a thick deposit of alluvium.

The geologic column in the area mapped is as follows:

Quaternary.

Formations in the St. Louis quadrangle.

Recent.

Alluvium.

Terrace deposits.

Pleistocene.

Wisconsin.

Loess.

Illinoian drift.

Kansan drift.

Unconformity.

Tertiary.

Lafayette gravel.

Unconformity.

Carboniferous.

Pennsylvanian ("Coal Measures").

Mississippian.

Chester group (?).

Birdsville formation (?).

$a$ Helm, E. G., Jour. Assoc. Eng. Soc., vol. 35, 1905, p. 96. 
Carboniferous-Continued.

Mississippian-Continued.

Meramec group.

St. Louis limestone.

Spergen limestone.

Warsaw shale.

Osage group.

Keokuk limestone.

Burlington limestone.

Kinderhook formation.

Fern Glen limestone member.

Bushberg sandstone member.

Devonian (?).

Glen Park limestone member.

Ordovician.

Richmond group.

Maquoketa shale.

Fernvale limestone.

Kimmswick limestone.

Plattin limestone (Black River, Lowville, and Stones River).

Joachim limestone.

St. Peter sandstone.

Cambro-Ordovician.

Jefferson City limestone.

Roubidoux formation.

Gasconade formation.

Proctor limestone.

Potosi limestone.

Cambrian.

Elvins formation.

Bonne Terre limestone.

La Motte sandstone.

None of the rocks beneath the Osage group outcrop in this area. A few miles west of the area, however, and likewise a few miles to the south, there are outcrops of the Kinderhook formation, at the base of the Mississippian, and the upper strata of the Ordovician. The formations outcropping near but not within the area mapped are discussed briefly here because they are reached by deep wells in St. Louis.

DETAILED WELL SECTIONS.

Among the wells more than 2,000 feet deep in and near St. Louis there are three or more in the drilling of which the strata were observed with care. These records furnish most of what is known directly of the deeper rocks beneath the St. Louis quadrangle. The sections of these wells are therefore given and will be found useful for frequent reference in reading what follows.

\section{WELI NEAR MONKS MOUND.}

A well was drilled for oil about the year 1903 on a small mound about 1,000 feet southwest of Monks Mound and about 7 miles northeast of the Eads Bridge. The altitude at the mouth of the well is 
approximately 435 feet. At least 100 samples were carefully taken by S. L. Shellenberger, of East St. Louis, and their depth recorded on labels. The samples were placed in bottles and presented to the St. Louis Academy of Science. The following log is made up from a study of these samples, its interpretation being in part the work of E. O. Ulrich. The identification of one or two formations and the exact boundaries of several others are in doubt, as will appear from the method of grouping adopted.

Log of well near Monks Mound, Illinois.

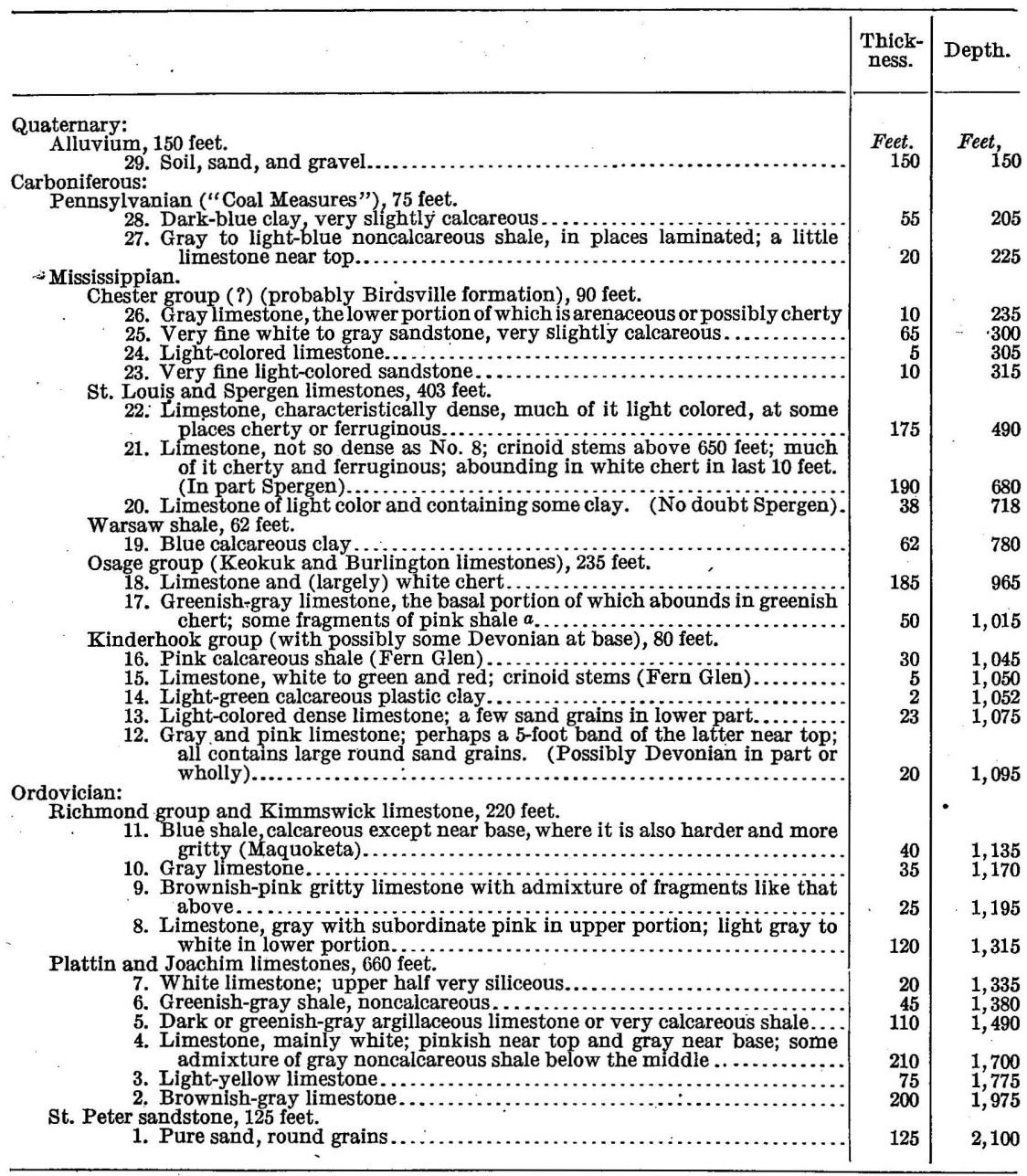

$a$ It is possible that the basal portion of No. 17 should be classed with the Kinderhook; there is no sharp break.

\section{WELI AT THE INSANE ASYLUM.}

A well was drilled about forty years ago 5 miles west-southwest of the St. Louis post-office, at an elevation of 590 feet, to obtain a supply of good water for use at the insane asylum. C. W. Atkinson, who

74449 ${ }^{\circ}$-Bull. $438-11-2$ 
superintended the work, took samples every few feet and labeled them so as to show their depth. He also kept a log of the well which is on record in the office of the county clerk. The log given below was made up from a careful study of the samples by G. C. Broadhead, ${ }^{a}$ at that time State geologist of Missouri. The original publication gives some additional details.

Log of well at the insane asylum, St. Louis.

[Prepared by G. C. Broadhead. The geologic names in brackets are the identifications of E. O. Ulrich.]

\begin{tabular}{|c|c|c|}
\hline & $\begin{array}{l}\text { Thick- } \\
\text { ness. }\end{array}$ & Depth. \\
\hline $\begin{array}{l}\text { Quaternary: } \\
\text { Bluff, } 40 \text { feet. }\end{array}$ & \multirow{2}{*}{$\begin{array}{r}\text { Feet. } \\
40\end{array}$} & \multirow{2}{*}{ Feet. ${ }_{40}$} \\
\hline \multirow{2}{*}{\multicolumn{3}{|c|}{$\begin{array}{l}\text { Carboniferous: } \\
\text { Coal Measures [Pensylvanian], } 80 \text { feet. }\end{array}$}} \\
\hline & & \\
\hline 33. Coal, clay, and limestone & \multirow{3}{*}{$\begin{array}{l}21 \\
25 \\
34\end{array}$} & \multirow{3}{*}{$\begin{array}{r}61 \\
86 \\
120\end{array}$} \\
\hline $\begin{array}{l}\text { 32. Shale, limestone, coal, and clay......................... } \\
\text { Carboniferous. }\end{array}$ & & \\
\hline $\begin{array}{l}\text { [St. Louis, } 318 \text { feet.] } \\
\text { 31. Cherty limestone, blue, drab, and gray; upper part fine grained; lower }\end{array}$ & & \\
\hline 30. phale coarse & \multirow{2}{*}{$\begin{array}{r}139 \\
3 \\
176\end{array}$} & \multirow{2}{*}{$\begin{array}{l}259 \\
262 \\
438\end{array}$} \\
\hline $\begin{array}{l}\text { 29. Drab cherty limestone; last } 18 \text { feet may belong with No. } 8 \text {. } \\
\text { 29eet. }\end{array}$ & & \\
\hline $\begin{array}{l}\text { [Spergen lir } \\
28 . \mathrm{Dal}\end{array}$ & & \multirow{2}{*}{500} \\
\hline [Warsaw shale, 36 feet.] & & \\
\hline $\begin{array}{l}\text { 27. Drab limestone and shales......... } \\
\text { [Osage group (including top of Kinderhook), } 254 \text { feet.] }\end{array}$ & 36 & \multirow[t]{2}{*}{536} \\
\hline $\begin{array}{l}\text { [Osage group (ine cherty limestone.............................. } \\
26 . \text { Hard blue }\end{array}$ & \multirow{3}{*}{$\begin{array}{r}92 \\
75 \\
6\end{array}$} & \\
\hline 25. Limestone & & \multirow{4}{*}{$\begin{array}{l}628 \\
703 \\
709 \\
790\end{array}$} \\
\hline 24. Sands & & \\
\hline 23. $\mathrm{Cl}$ & 81 & \\
\hline Chouteau [Kinderhook] group, 93 feet. & \multirow{4}{*}{$\begin{array}{l}10 \\
35 \\
48\end{array}$} & \\
\hline $\begin{array}{l}\text { 22. Red limestone } \\
\text { 21. Drab and gray limestone and chert. }\end{array}$ & & \multirow{2}{*}{$\begin{array}{l}800 \\
835 \\
883\end{array}$} \\
\hline 20. Dark limestone with some clay and chert. & & \\
\hline $\begin{array}{l}\text { Lower Silurian [Ordovician; Devonian at top (?)]: } \\
\text { Trenton, Black River, and Birdseye limestone [Devonian at top (?)], } 421 \text { feet. }\end{array}$ & & \multirow{3}{*}{$\begin{array}{r}966 \\
1,022\end{array}$} \\
\hline $\begin{array}{l}\text { 19. Clay [Maquoketa]......... } \\
\text { 18. Blue shales and limestone }\end{array}$ & \multirow{2}{*}{$\begin{array}{l}83 \\
56\end{array}$} & \\
\hline 18. (Limestone with magnesian bands; cream colored and magnesian & & \\
\hline 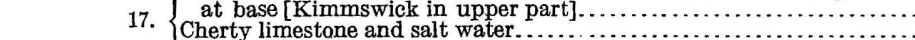 & \multirow{2}{*}{$\begin{array}{r}194 \\
9 \\
79\end{array}$} & \multirow{2}{*}{$\begin{array}{l}1,216 \\
1,225 \\
1,304\end{array}$} \\
\hline Light and dark limestone: & & \\
\hline First limestone, 148 feet. & \multirow{3}{*}{$\begin{array}{l}49 \\
99\end{array}$} & \multirow{3}{*}{$\begin{array}{l}1,353 \\
1,452\end{array}$} \\
\hline - 16. Drab cherty limestone $\ldots \ldots \ldots$ Magnesian limestone [Joachim]... & & \\
\hline $\begin{array}{l}\text { Saccharoidal sandstone [St. Peter], } 133 \text { feet. } \\
\text { 14. Sandstone of rounded grains; white and containing sulphur water above; }\end{array}$ & & \\
\hline newhat brown in lower portion................................... & \multirow[t]{2}{*}{133} & \multirow[t]{2}{*}{1,585} \\
\hline Second limestone [Jefferson City], 517 feet. & & \\
\hline and drab cherty magnesian limestone. & $\begin{array}{l}128 \\
389\end{array}$ & \multirow{2}{*}{$\begin{array}{l}1,713 \\
2,102\end{array}$} \\
\hline $\begin{array}{l}\text { 12. Buff and drab cherty magnes } \\
\text { Second sandstone [Roubidoux], } 82 \text { feet. }\end{array}$ & 389 & \\
\hline $\begin{array}{l}\text { 11. Sandstone, hard and mostly pure; subordinate cherty limestone........ } \\
\text { Third limestone, } 838 \text { feet [probably includes Gasconade, Proctor, and Potosi lime- } \\
\text { stone]. }\end{array}$ & 82 & 2,184 \\
\hline 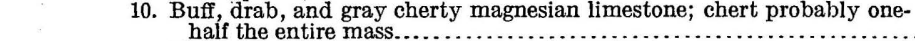 & & \multirow{3}{*}{$\begin{array}{l}2,671 \\
2,843 \\
2,880 \\
3,022\end{array}$} \\
\hline 9. Magnesian limestone with some sand; no c & \multirow{2}{*}{$\begin{array}{r}487 \\
172 \\
37 \\
142\end{array}$} & \\
\hline Magnesian limestone. & & \\
\hline
\end{tabular}

$a$ Trans. St. Louis Acad. Sci., vol. 3, 1873, p. 216. It is understood that this study was made some years after the well was drilled and the samples stored. Whatever interference with or mixing of the samples may bave occurred in the meantime, Broadhead's log differs little from that which was filed by the superintentendent. Furthermore, on comparison of this $\log$ with the logs of the other deep wells it is seen to be consistent.

During the drilling of this well Prof. Hambach, of Washington University, St. Louis, took samples with great regularity and systematically kept a log from day to day which he platted on a large scale. Some years later this log passed into the hands of Charles A. Ashburner, of Pennsylvania, but it can not now be located. It is greatly to be regretted that this full and accurate information concerning one of the deepest wells in the world should have been lost. 
Log of well at the insane asylum, St. Louis-Continued.

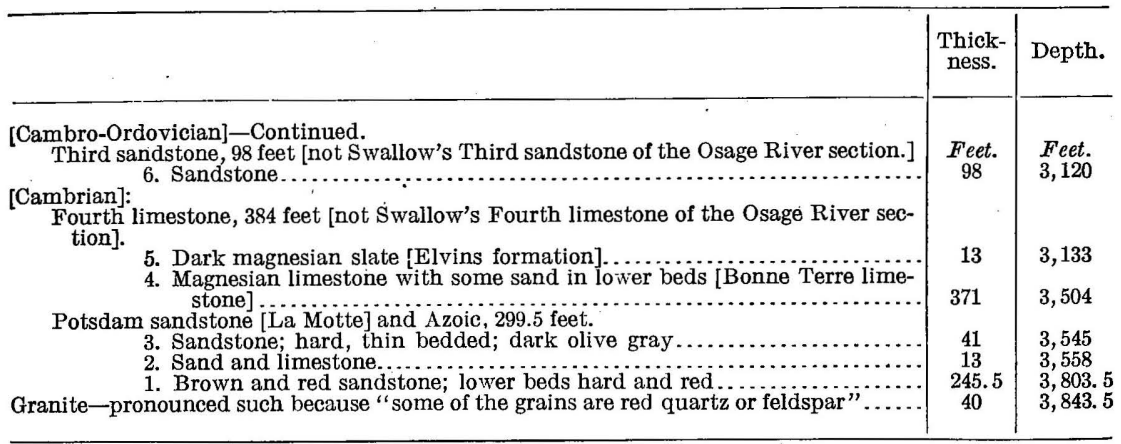

\section{BELCHER WELL.}

The Belcher well, at Second and O'Fallon streets, St. Louis, half a mile north of the Eads Bridge, is famous for its mineral water. It was finished in 1854 and is 2,199 feet deep. The altitude at the surface is 420 feet. The log of the well was kept by Louis Holm and subsequently studied and prepared for publication by A. Litton, M. D.

Log of the Belcher well, St. Louis. ${ }^{a}$

[Prepared by A. Litton, M. D.]

\begin{tabular}{|c|c|c|}
\hline & $\begin{array}{l}\text { Thick- } \\
\text { ness. }\end{array}$ & Depth. \\
\hline $\begin{array}{l}\text { Carboniferous, } 630 \text { feet. } \\
\text { Limestone with chert; a few inches of shale } 30 \text { feet below top }\end{array}$ & $\begin{array}{l}\text { Feet. } \\
265\end{array}$ & Feet. \\
\hline 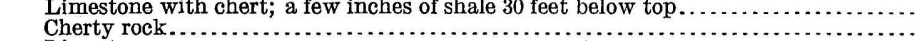 & $\begin{array}{r}2 n 5 \\
12\end{array}$ & 265 \\
\hline Limestone.................... & 73 . & 350 \\
\hline $\begin{array}{l}\text { Shale.................................... } \\
\text { Limestone, with shaleak } 455 \text { feet. }\end{array}$ & $\begin{array}{r}30 \\
115\end{array}$ & 380 \\
\hline 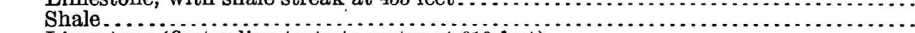 & 10 & 505 \\
\hline $\begin{array}{l}\text { Limestone (first saline taste to water at } 610 \text { feet) } \ldots \ldots \ldots \ldots \ldots \ldots \ldots \ldots \ldots \ldots \ldots \ldots \\
\text { Chemung (?) } 95 \text { feet. }\end{array}$ & 125 & \\
\hline 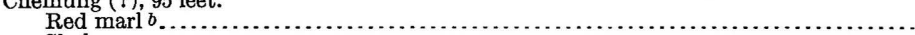 & 18 & 648 \\
\hline Shale............... & & 675 \\
\hline $\begin{array}{l}\text { Red marl ................ } \\
\text { Upper Silurian or Chemung (?), } 37 \text { feet. }\end{array}$ & 50 & 725 \\
\hline 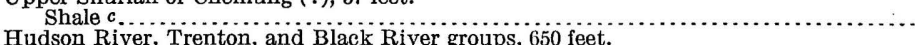 & 37 & 762 \\
\hline 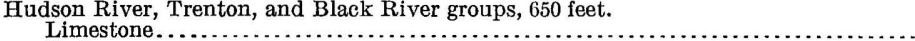 & 121 & \\
\hline & 67 & 950 \\
\hline Bituminous marl.... & 18 & 968 \\
\hline $\begin{array}{l}\text { Shale........ } \\
\text { Limestone.. }\end{array}$ & $\begin{array}{r}77 \\
138\end{array}$ & $\begin{array}{l}1,045 \\
1,183\end{array}$ \\
\hline Cherty rock.. & 57 & 1,240 \\
\hline … & 130 & 1,370 \\
\hline Shale.... & 15 & 1,385 \\
\hline $\begin{array}{l}\text { Limestone...................... } \\
\text { Magnesian limestone series, } 787 \text { feet. }\end{array}$ & 27 & 1,412 \\
\hline & 50 & 1,462 \\
\hline Limestone ................. & 30 & 1,500 \\
\hline White soft sandstone $d . \ldots \ldots \ldots$. & 140 & 1,640 \\
\hline $\begin{array}{l}\text { Sandstone with much iron } e_{\ldots . \ldots} \\
\text { Sandstone with clay............ }\end{array}$ & 185 & 1,825 \\
\hline Sandstone with lime and & 179 & 2,199 \\
\hline
\end{tabular}

$a$ Trans. St. Louis Acad. Sci., vol. 1, p. 80.

$b$ Now classed as Fern Glen limestone, member of the Kinderhook formation.-N. M. F.

c Probably Maquoketa. - N. M. F.

$e$ The lower 559 feet, determined as sandstone by Litton, probably consists mainly of dolomitic limestone.-E. O. U. 


\section{ORDOVICIAN SYSTEM.}

In this area the upper formations of the Ordovician system are significant chiefly as horizon markers in deep-well sections. The readily recognizable character of one of them has greatly facilitated the interpretation of well logs and thereby the determination of structural features. The treatment here of formations not exposed within the area mapped has therefore primary reference to their position in the column and to the prominent characteristics which make them easily recognizable.

ST. PETER SANDSTONE.

The St. Peter sandstone (known also as the "Saccharoidal" sandstone, "First" sandstone, "Crystal City" sandstone, "Pacific" sandstone, and "Cap au Gres" sandstone) is composed almost entirely of well-rounded grains of generally translucent quartz, medium to large in size and poorly cemented with silica. Partly because of the deficiency in cement and partly because of the roundness of the grains, the rock is very friable. It may be almost pure white or stained with iron oxide to various shades of yellow, pink, or even red. In places the iron stain occurs in irregular blotches or incipient concretions. The thickness of the formation at Pacific, 34 miles west of St. Louis, is at least 110 feet. (See PI. III, A.) The well at the insane asylum, St. Louis, is believed to pass through 133 feet of this formation. The thickness, however, varies from 200 feet down to the vanishing point, the sandstone being unconformable both above and below.

Formations above the st. PETER sandstone.

Overlying the St. Peter sandstone, and like it not outcropping within the area mapped on Plate I, are 600 to 800 feet or, more of limestones and shales which were not studied in detail. They represent the Plattin, Joachim, and Kimmswick(Ordovician) limestones, the Maquoketa shale (upper Ordovician), and possibly also some Devonian shale and limestone. The limestones may be seen in descending order in outcrops or railroad cuts in going from Fern Glen, 20 miles west of St. Louis, to Pacific Junction, 14 miles farther west. Both the limestones and the overlying shales are shown in railroad cuts south of Kimmswick, which is 20 miles south of St. Louis. These formations occupy in the Belcher well section the interval from 725 to 1,505 feet, in the asylum well from 883 to 1,452 feet, in the Monks Mound well from 1,095 to 1,975 feet. 


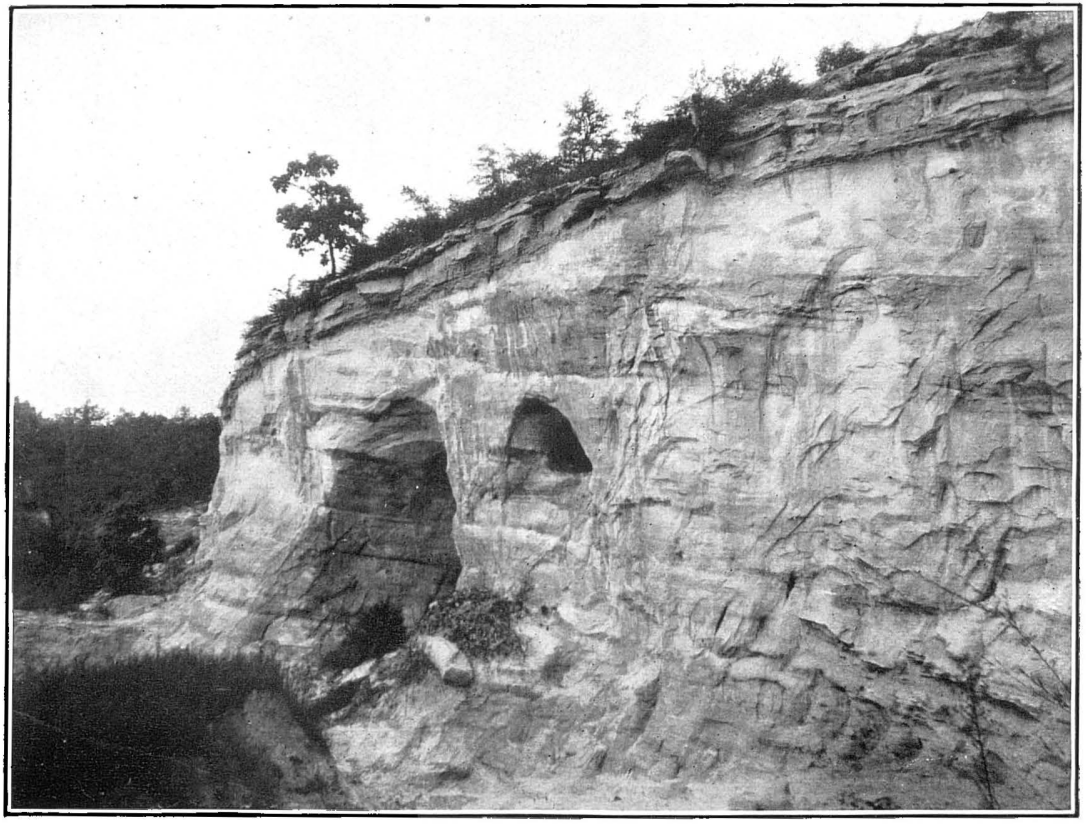

'A. St. peter sandstone capped by limestone, pacific, mo.

(See page 18.)

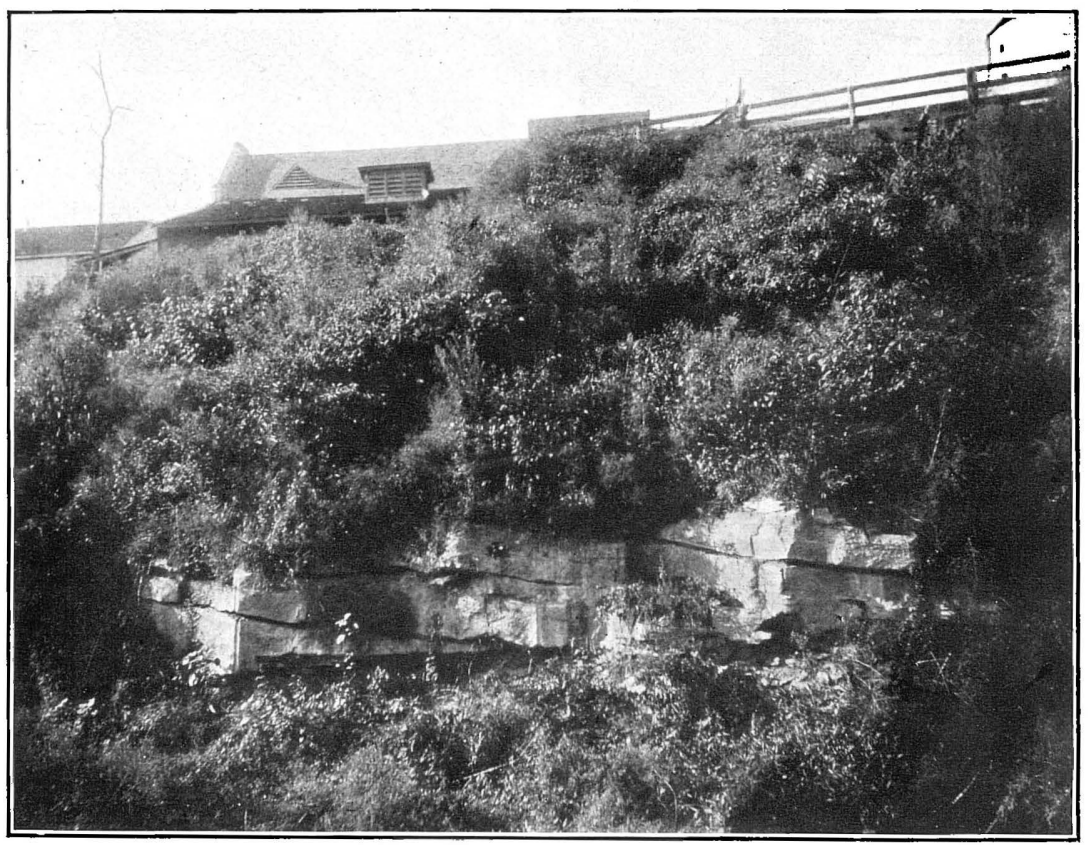

B. CROSS-BEDDING IN SPERGEN LIMESTONE, MERAMEC hIGHLANDS, MO.

(See pages 22-23.) 



\section{CARBONIFEROUS SYSTEM.}

MISSISSIPPIAN SERIES.

KINDERHOOK FORMATION.

Like the Ordovician formations named above, the Kinderhook does not outcrop within the area mapped. Its prominence in the well logs, however, requires its description in some detail. It contains several distinct members, arranged from above downward as follows:

4. Greenish-gray cherty limestone (supposed base of Burlington, but may be in part Kinderhook).

3. Pink calcareous cherty shale and limestone, with locally a 4-foot massive gray to greenish limestone at base (Fern Glen limestone member).

2. Yellow friable sandstone (Bushberg sandstone member, local).

1. Gray limestone, in many places containing sand grains (Glen Park limestone member, local).

These members of the Kinderhook are well exposed at Glen Park, 23 miles south of St. Louis, where the section is as follows:

Section at Glen Park, Mo.a

11. Cherty limestone (Burlington) $\ldots \ldots \ldots \ldots \ldots \ldots \ldots \ldots \ldots \ldots \ldots \ldots$

10. Cherty greenish-gray limestone (Burlington) [may contain some Kinderhook near base $] \ldots \ldots \ldots \ldots \ldots \ldots \ldots \ldots \ldots \ldots \ldots . \ldots \ldots$

9. Red, more or less argillaceous, limestone and chert with greenish blotches (Fern Glen)..................... 86

8. Unexposed, probably a softer red calcareous shale covered with talus (Fern Glen) $\ldots \ldots \ldots \ldots \ldots \ldots \ldots \ldots \ldots \ldots \ldots$

7. Hard, somewhat crystalline yellow or gray limestone [undoubtedly a part of the Fern Glen].................... 4

6. Yellow fine-grained sandstone, becoming brown on the weathered surface (Bushberg sandstone) . . . . . . . . . . . . 14

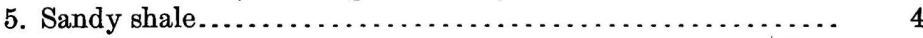

4. Limestone, coarse, light gray, oolitic, and fossiliferous (Glen Park limestone $). . \ldots \ldots \ldots \ldots \ldots \ldots \ldots \ldots \ldots \ldots \ldots \ldots \ldots$

3. Dull yellow shales and shaly limestone (Maquoketa)......... 4

2. Hard, dark-colored, brown or bluish fossiliferous limestone (Richmond) [Fernvale]......................... 16

1. Kimmswick limestone (Trenton fossils) .............. 55

The upper Kinderhook is likewise typically exposed at Fern Glen, 20 miles west of St. Louis, and from this place the name Fern Glen limestone member is taken. The section at Fern Glen is as follows:

\section{Section at Fern Glen, Mo.b}

5. Cherty limestone (Burlington; may contain some Kinderhook

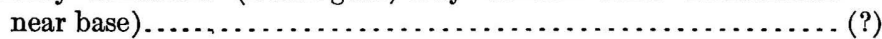

4. Greenish calcareous shale, with chert bands and nodules, becoming reddish near base and grading into No. $3 \ldots \ldots \ldots \ldots \ldots \ldots . . .14$

3. Red calcareous, highly fossiliferous shales, with chert and some

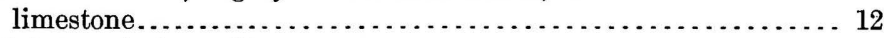

2. Pink to red cherty limestone........................ 14

1. Buff to greenish limestone with crystalline crinoid stems........ 4

$a$ Weller, Stuart, Kinderhook faunal studies: Trans. St. Louis Acad. Sei., vol. 16, 1906, pp. 435-438. The notes in brackets are supplied by the present writer.

$b$ The measurements in this section are taken from Weller's unpublished notes. 
Beds 1 to 4 in the above section constitute the Fern Glen limestone member of the Kinderhook formation.

The cherty limestone above the shale, between the Osage group and the Fern Glen limestone member, is physically continuous with the overlying Osage, from which it is with difficulty delimited because of the lack of a sharp break in the character of the fossils. The thickness of this limestone, therefore, which should be classed with the Kinderhook, is uncertain.

No. 3, in the general section of the Kinderhook (p. 19), is the Fern Glen limestone member and is found wherever this horizon is exposed or drilled through, in and near the area studied. Its striking characteristics are its pink or red color and its large proportion of shale. At Fern Glen (see p. 19) it grades from a pure massive limestone at the base to shale at the top. Its red color is most pronounced in the middle, and it is cherty throughout, with the exception of the massive limestone at its base. The appearance of the Fern Glen limestone member at Glen Park (Nos. 7 to 9 of the section at that place) is essentially the same, though limestone forms a somewhat greater proportion of the whole than at Fern Glen. Among the characteristic fossils of this member are Zaphrentis (several species), Cyathaxonia sp., Evactinopora sp., Leptæna rhomboidalis, Rhipidomella (small species), Spirifer vernonensis, Spirifer imbrex, Athyris prouti, and Athyris lamellosa.

OSAGE GROUP (BURLINGTON AND KEOKUK LIMESTONES).

Overlying the Fern Glen limestone member is from 200 to 250 feet of cherty limestone doubtless comprising both the Burlington and the Keokuk limestones. Because of the continuity of character throughout and the absenee of a decided paleontologic break, all these beds are treated together here under the more comprehensive term Osage group.

The outcrops of this group within the area mapped are limited to the southwest corner of the quadrangle, in the valley of Meramec River. In this area only the upper 100 feet is exposed and all the fossils found are of Keokuk age.

The limestone is characteristically light colored and thin bedded, the thickness of the several beds being generally a fraction of a foot, but in extreme cases reaching several feet. The one conspicuous physical characteristic of these rocks is the great abundance of chert. Throughout their greater part chert constitutes approximately hall of the mass. The chert is distributed in beds, irregular zones, and bands of concretions more or less separated into individual units, some elliptical and even spherical. The prevailing form is in beds of irregular thickness and wavy surfaces, so that on a casual view an exposure gives the impression of irregularly interbedded limestone 
and chert. The chert is commonly gray. Individual concretions may be beautifully banded. On weathering it becomes white, or superficially red, by oxidation of iron. Nodules are not uncommonly embedded in a red residual clay. On surfaces long exposed the chert is much broken into irregular or prismatic small blocks, or may have acquired a cavernous surface through solution.

Within the limestone beds recrystallization is common. The cleavage faces of the resulting crystals give to a newly broken surface a sparkling appearance. The great abundance of fragments of crinoid stems and other fossils suggested the old name "Encrinital limestone." These fossil fragments, themselves usually calcitized, unite their effect with that of the calcite crystals in the matrix to give to the rock a very coarse grain. This is a characteristic though not a universal feature of the entire formation. On some weathered surfaces the fossil fragments stand out with peculiar boldness.

Near the top the formation is locally shaly, a general section of the entire Osage in this quadrangle being as follows:

Section of Osage group in St. Louis quadrangle.

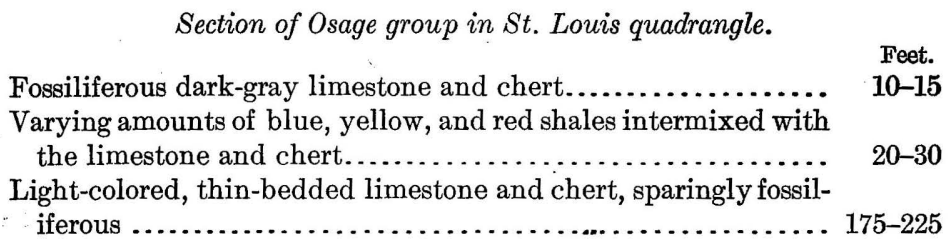

The characteristic fossils of the upper part of the great mass of cherty limestone are the crinoid stems mentioned above and large brachiopods, among which Spirifer logani is prominent. Near the top there are also Archimedes and other bryozoans, with an occasional trilobite. Fully 50 feet below the top of the formation there is locally a 2 or 3 foot bed of limestone, free from chert and carrying a fauna with some Spergen affinities. (See "Geologic history," p. 40.)

MERAMEC GROUP.

Warsaw shale.-Overlying the Osage group is the Warsaw shale, 75 feet thick, which is chiefly composed of shale, though containing subordinate limestone beds. Like the Osage rocks, it outcrops only in the southwest corner of the St. Louis quadrangle. On account of its weakness it is rarely exposed at the surface. In the basal zone of this formation, varying from 10 to 20 feet in thickness, the amount of limestone exceeds that of shale. As this limestone is cherty, like that below, and as its fossils are not very different from those of the Keokuk, there may be a question as to where it should be classed. It is in fact transitional, though placed for convenience with the overlying shale. The limestone is darker in color and dense, lacking the coarse grain of the typical encrinital beds below. The 
chert is generally of a dark-reddish color and is smaller in amount and more nodular in form than that in the Osage group.

The body of the formation is of soft shale, blue in great part but yellowish near the summit. This portion, however, also includes subordinate beds of limestone, one of which, about 4 feet thick and some 20 feet above the basal limestones, contains Spirifer keokuk in such abundance as to make the horizon easily recognizable. The stone of this bed is granular.

Both shale and limestone, especially the latter, are fossiliferous. The characteristic types are crinoid stems, brachiopods, and Archimedes wortheni, with other bryozoans.

Spergen limestone.-The top of the Warsaw is sharply marked by a contact of the shale with a thick-bedded granular limestone. With slight variations this limestone, the Spergen, continues upward for a thickness of at least 60 feet. (See Pl. III, B.)

Like the lower formations, the Spergen is found chiefly in the southwest corner of the St. Louis quadrangle, where it caps the uplands, outcropping in many ledges on the upper slopes of the Meramec Valley where the loess has been eroded away. It also appears at the surface in several other valleys, notably in the Illinois bluff of the Mississippi on the southern margin of the area mapped and in the bottom of one or two quarries in the bluff at St. Louis.

A well-exposed section of the Spergen at the quarry just east of the Meramec Highlands station on the St. Louis and San Francisco Railroad is as follows, the order here given being from top to bottom:

Section of Spergen limestone at quarry near Meramec Highlands, Mo.a

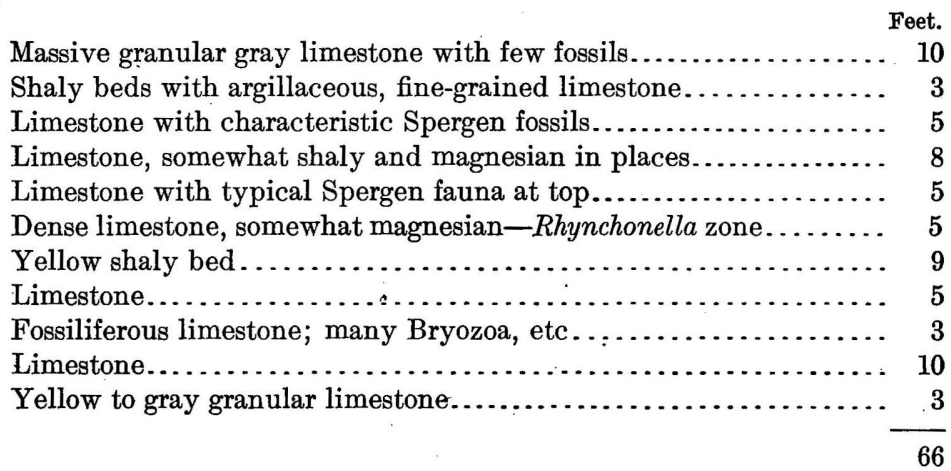

The Spergen is physically distinguished from the Warsaw below by the abrupt transition from shale to limestone, though very subordinate shale beds occur also in the upper formation. Locally it is distinguished with almost equal clearness from the overlying St. Louis limestone by its lack of chert, which within this area is invariably present in the St. Louis and is in many places abundant. Elsewhere 
the line separating the Spergen from the succeeding formation is less definite.

The most characteristic phase of the Spergen is a thick-bedded, in places cross-bedded ( $\mathrm{Pl}$. III, $B$ ), pure granular fossiliferous gray limestone carrying the Spergen Hill (Indiana) fauna and having a striking resemblance in physical character to the well-known "Bedford" (Indiana) limestone of commerce. This phase prevails rear the middle. Locally it is a closely packed mass of fossil shell fragments or a conglomerate of unbroken Rhynchonella shells. Such a zone may be found some 30 feet from the top. In some places it is 6 inches or more in thickness and composed entirely of Rhynchonella sp.; elsewhere the fossils are less closely packed throughout a thickness of several feet.

At other horizons the coarse grain of the "Bedford" type gives way to fine grain, exemplified by the topmost ledge of 10 feet, which is very massive, dense, and gray, and is affected by stylolitic structure. In general, this bed resembles the overlying St. Louis except for its entire lack of chert. Immediately beneath this topmost ledge is a zone of about 5 feet in which shales occur locally but grade laterally into argillaceous or fine-grained limestone. Similar shale bands, some of them persisting for a mile or more, occur below the Rhynchonella zone. The base of the formation, like its summit, contains dense beds having a magnesian appearance.

One fossil form characteristic of the Spergen is Rhipidomella dubia. Long-winged and finely plicated spirifers are also abundant near the base of the formation, and bryozoans likewise abound, especially in the lower half. In general the Spergen fauna is closely similar to that of the same formation in Indiana.

St. Louis limestone.-The St. Louis limestone, which overlies the Spergen, forms the bedrock of most of the area not underlain by Pennsylvanian rocks. Its thickness averages about 325 feet. This formation is almost wholly limestone, but contains local thin streaks of shale. The thickness of its beds varies from a few inches to many feet, and in some of the thicker layers cross-bedding is observed. Here and there a bed is also finely ripple marked. The formation as a whole may be described as at least slightly magnesian. The proportion of magnesium carbonate is usually low, but in a few beds it runs as high as 30 per cent.

The most obvious characteristic of the St. Louis limestone consists in its numerous beds which have the close texture and density of lithographic stone. Such rocks break with an almost glassy fracture and conchoidal form. This characteristic is most common in the thinner beds. As it is a striking feature and is not found in any other rocks of the vicinity, it offers a convenient and fairly trustworthy means of identifying the St. Louis limestone. It is rarely seen in the 
lowest third of the formation, but otherwise no rules can be given for its distribution.

Chert is abundant in the St. Louis limestone. It occurs at all levels, though many thick beds are at least locally free from it. In color it varies from gray to black and is in places banded like agate. Throughout the formation chert is most frequently seen in the form of nodules, but there are variations from isolated spherical nodules through bands of elliptical forms to beds of pure chert with more or less wavy surfaces. In places, indeed, the limestone assumes nodular forms within a chert matrix.

Here and there a bed is brecciated or incloses a brecciated zone between an upper and a lower portion which contain no suggestion of deformation. In some of such beds angular fragments of chert are embedded in a matrix of limestone; in others a band of chert shows a slight faulting not revealed by the limestone matrix. 'More' commonly the angular fragments are of the dense lithographic type and the matrix is of coarse granular limestone. (See Pl. IV, opposite.) One such zone, exposed in Eyerman's quarry on Grand avenue, near the center of St. Louis, lies between two massive beds, each about 4 feet thick, almost without joints, bounded by plane surfaces and showing no evidence whatever of deformation. This zone is approximately 50 feet above the base of the St. Louis.

A further peculiarity of the St. Louis consists in its local beds of nodular limestone, in which spherical concretions of limestone are embedded in a matrix of the same material. The concretions, which have a diameter of 1 to 2 inches, are dense and hard and many of them are concentrically marked. The matrix is apparently less pure, coarser in texture, and in places shaly. Here and there such beds contain or adjoin thin bands of green shale or clay and in many beds of this character the limestone nodules, though not formed within the clay, protrude prominently from the surface of the limestone and indent the clay. Elsewhere interbedded limestones and clays both contain such concretions. These nodular limestones characterize two horizons, the higher being not more than 25 feet from the summit of the formation and the other about 100 feet lower. Both are shown in the quarries on North Broadway, near the Merchants Bridge.

The St. Louis is sparingly fossiliferous, the characteristic forms being Lithostrotion canadense, Cystodictya lineata sancti-ludovici, Dichotrypa intermedia, Dichotrypa elegans, Derbya kaskaskiensis, Productus marginicinctus, and Spirifer littoni.

CHESTER GROUP (?).

In the section of the Monks Mound well the rocks for 90 feet above the St. Louis limestone are provisionally classed as Chester, 


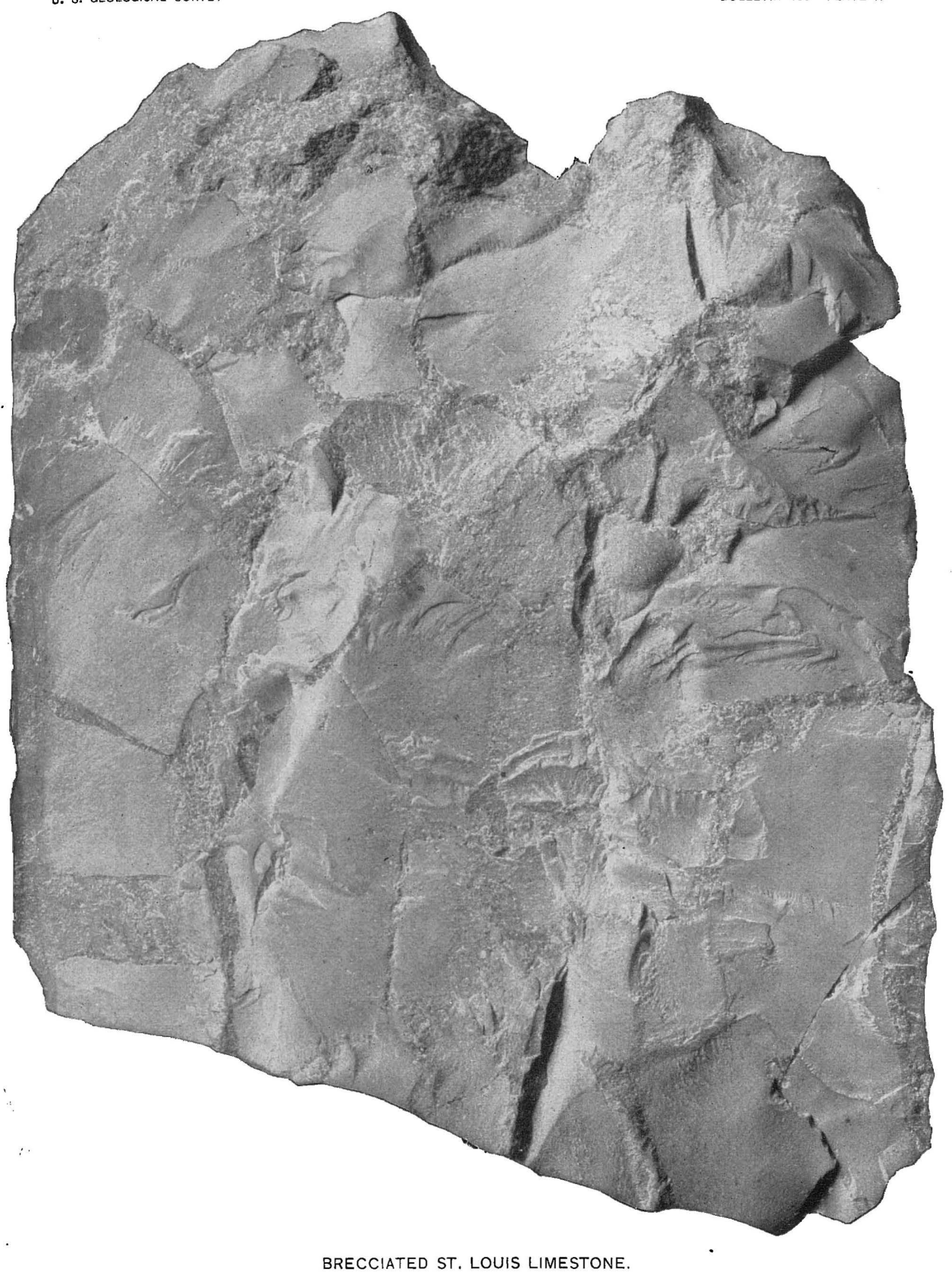

The angular fragments are of the dense, fine-grained variety; the matrix is coarsely granular. (See page 24.) 

75 feet of this being a fine white or gray sandstone, and the remaining 15 feet a gray limestone, a part of which is either arenaceous or cherty. A like thickness of water-bearing sandstone overlies the St. Louis limestone in wells at Belleville.

Rocks of Chester age do not outcrop within this area. Where the westward overlapping base of the Pennsylvanian rocks is exposed it rests unconformably on the St. Louis limestone, the Chẹster (?) noted in the Monks Mound well apparently wedging out before reaching the west side of the Mississippi.

PENNSYLVANIAN SERIES ("COAL MEASURES").

GENERAL CHARACTER.

The Pennsylvanian in the western part of this area rests unconformably on the St. Louis; elsewhere on the rocks that are here provisionally regarded as Chester. It consists of shale and clays, limestone, sandstone, and coal, named in the order of abundance. Most of the beds are believed to be of slight lateral extent, and sections having the same vertical range differ greatly in detail. West of the Mississippi the entire thickness slightly exceeds 100 feet. East of the river the thickness is more than 400 feet. The correlation of beds on opposite sides of the river is uncertain.

Within and near the city of St. Louis many shafts of fire-clay mines traverse the entire thickness of the Pennsylvanian series. A much generalized section at that place is as follows:

Section of Pennsylvanian series in the Cheltenham district, St. Louis.

\begin{tabular}{|c|c|}
\hline & Feet. \\
\hline Weathered limestone ("tumble rock")....... & \\
\hline 1. Pipe clay, etc., maximum.. & 15 \\
\hline 10. Coal (local). & $0-4$ \\
\hline 9. Limestone or "very hard blue rock". & $3-15$ \\
\hline 8. Red and blue clays "keel," pipe clay, etc. & $13-36$ \\
\hline 7. Coal (very local) ....... & $0-1 \frac{1}{2}$ \\
\hline 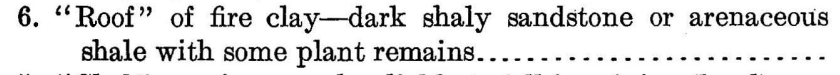 & $1-7$ \\
\hline 5. "Clod"-an impure clay liable to fall in mining (local).... & $0-\frac{2}{3}$ \\
\hline 4. Coal streak (very local)... & $0-\frac{1}{4}$ \\
\hline 3. Fire clay, Cheltenham bed............................. & $2 \frac{1}{2}-12$ \\
\hline 2. Light-colored sandstone with pyritic crystal & \\
\hline & \\
\hline
\end{tabular}

As illustrations, the actual sections of two shafts are given below: Section at Jamieson-French mine, $1 \frac{1}{2}$ miles south of Clayton, Mo.

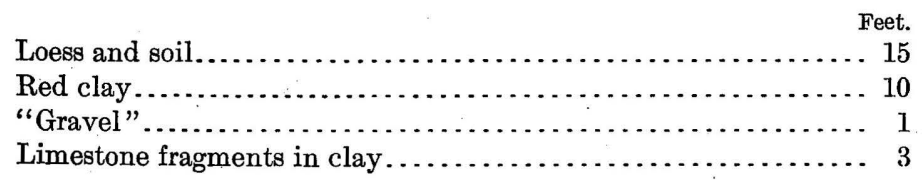




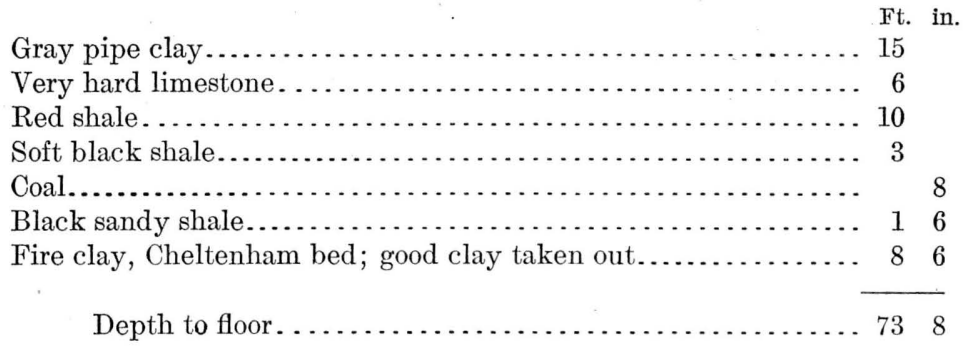

Beneath the good fire clay in this mine is several feet of green or iron-stained clay that is not mined. This is underlain by a pyritiferous sandstone of unknown thickness, probably at least 6 feet. At an outcrop half a mile to the south this sandstone is underlain by limestone containing large red cherts.

Section at Krümmel \& Büchner mine, Columbia avenue and Woods street, St. Louis.

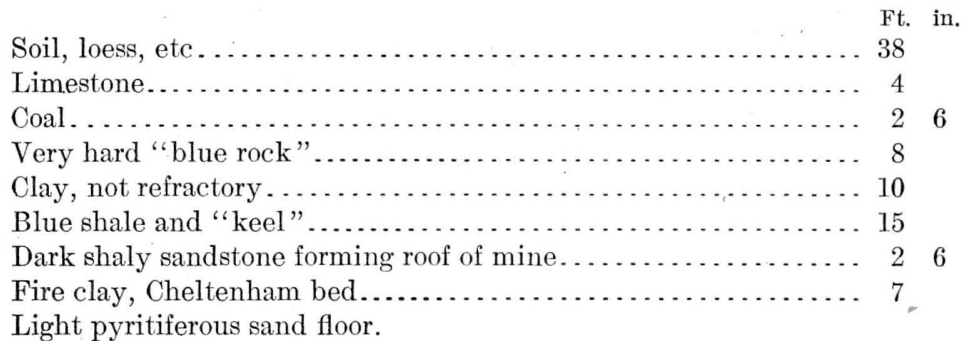

Depth to floor

Northwest of St. Louis, near Creve Cœur Lake, shafts and borings show the general section of the Pennsylvanian to be about as follows:

Section of Pennsylvanian rocks near Pattonville, Mo.
12. Red shale
Feet.

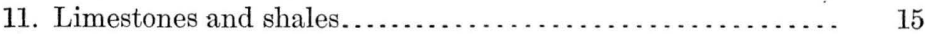
10. Sandstone, massive and ferruginous.................. 20
9. Shales, blue and brown.......................... . 10-15
8. Thin-bedded limestone, locally interbedded with shale... . . 10-18
7. Red and blue shales with locally a thin coal streak near

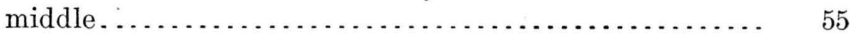

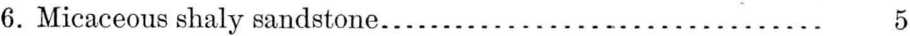

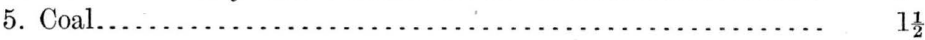

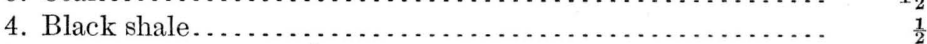

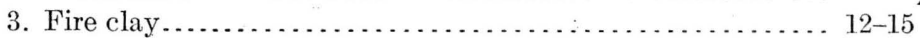
2. Sandstone with ferruginous nodules (a few feet).
1. Limestone.

It is instructive to compare with these sections the typical section of Swallow's Lower Coal Series, taken in the western part of the State. 


\section{Section of the Lower Coal Series (Swallow). ${ }^{a}$}

[Numbers at the left are from the original publication.]

60. Soft brown, heavy bedded, irregularly stratified micaceous sandstone, often passing toward the base into a more compact gray

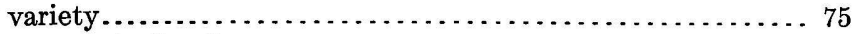

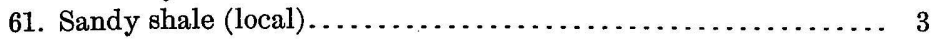

- $\quad 62$. Coal.......................................... 1

63. Bituminous and sandy shale (local) ................. 4

64. Coal (thinner in St. Louis County)................. 6

65. Argillaceous and sandy shale...................... 1

66. Fine, compact, hard blue and gray hydraulic limestone, frequently interstratified with clay and variegated with blue and gray spots; fossils abundant....................... 8

67. Bituminous and blue shales..................... 6

68. Coal..................................... $1 \frac{1}{2}$

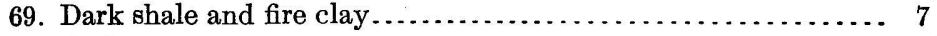

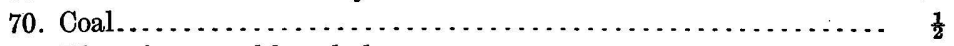

71. Bituminous or blue shales....................... 7

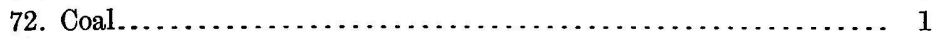

73. Bituminous shale............................ 4

74. Coal...................................... 3

75. Shale and fire clay (believed to include the Cheltenham bed). . 23

East of the Mississippi the character of the Pennsylvanian is clearly shown in the wells and mine shafts in and near Belleville. Two wells on the east side of the river showed the following sections:

Log of well at the vinegar factory, Belleville, Ill.

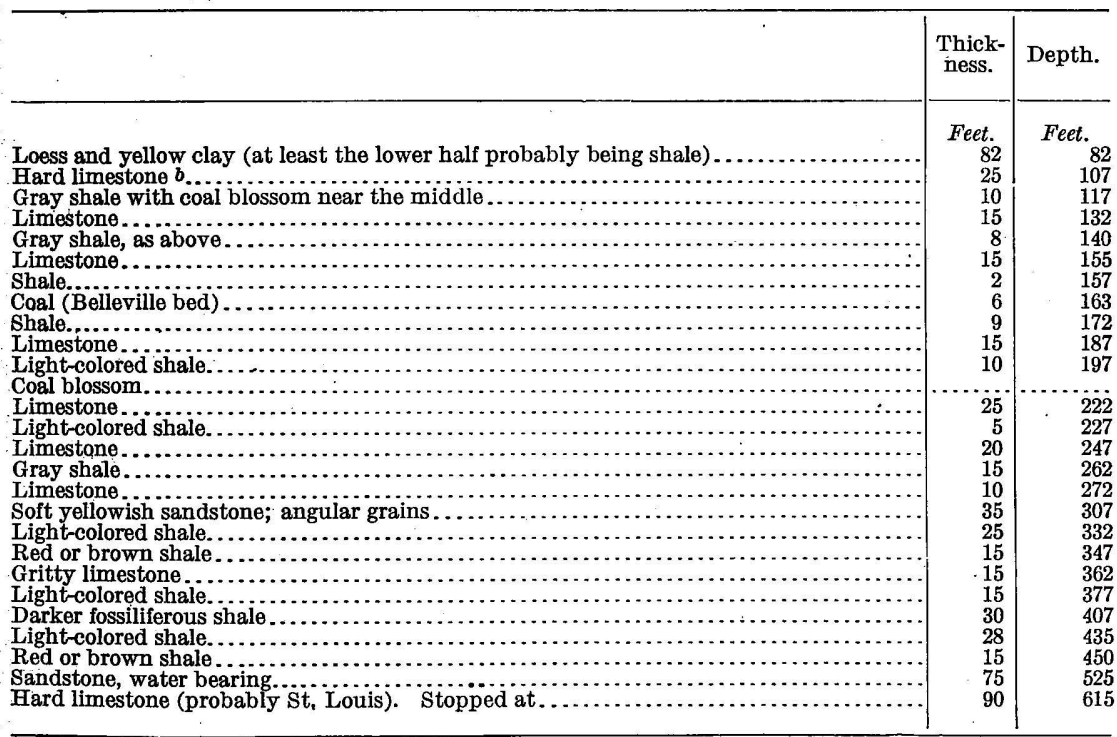

$a$ Geol. Survey Missouri, 1855 , p. 86 .

$b$ It is quite probable that much of the "limestone" here reported is in reality interbedded limestone and shale. 
Log of well drilled by the Illinois Hydraulic Press Brick Company near Collinsville, Ill.

\begin{tabular}{|c|c|c|c|c|}
\hline & $\begin{array}{l}\text { Thicl } \\
\text { ness }\end{array}$ & $\begin{array}{l}\text { ck- } \\
\text { s. }\end{array}$ & Depth & \\
\hline & Ft. $i$ & & & \\
\hline $\begin{array}{l}\text { 30. Surface clay } \\
\text { 29. Clay shale... }\end{array}$ & 40 & & 40 & \\
\hline 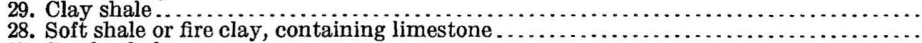 & 47 & & 87 & \\
\hline 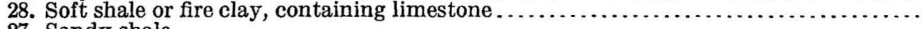 & 6 & & 93 & \\
\hline 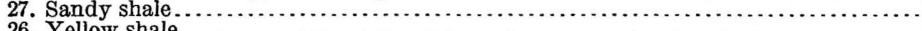 & 14 & & 107 & \\
\hline 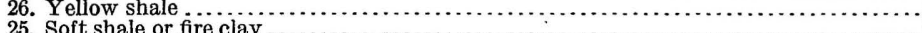 & 1 & & 108 & \\
\hline 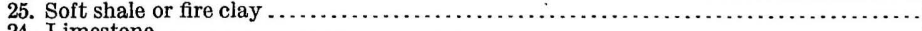 & 2 & & 110 & \\
\hline 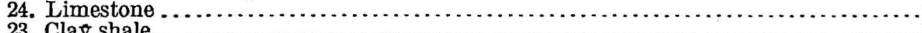 & 7 & & 117 & \\
\hline and shole & 6 & & 123 & \\
\hline $\begin{array}{l}\text { 22. Limestone, sandstone, and shale } \ldots \ldots \ldots \ldots \ldots \ldots \ldots \ldots \ldots \ldots \\
\text { 21. Limestone with black shale partings } . \ldots \ldots \ldots \ldots \ldots \ldots \ldots\end{array}$ & 17 & & 140 & \\
\hline 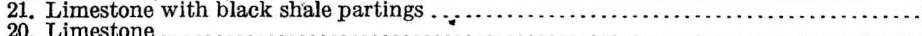 & 14 & & 154 & \\
\hline 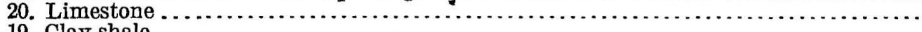 & 3 & & 157 & \\
\hline (n) & & 3 & 157 & \\
\hline & & & 163 & \\
\hline 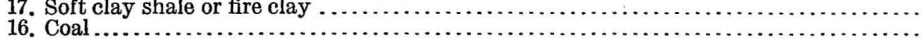 & & & 169 & \\
\hline 2 & & & 169 & \\
\hline 14. Limestone ............ & & & 180 & \\
\hline 13. Clay shale...... & 25 & & 183 & \\
\hline 12. Red shale ...... & 4 & & 213 & \\
\hline 11. Cla & 52 & & 265 & \\
\hline 10. Lir & 1 & & 266 & \\
\hline 9. Black "slate". & 2 & & 268 & \\
\hline 8. Coal. & & & 270 & \\
\hline 7. Fire clay & 8 & 6 & 279 & \\
\hline 6. Sa & 10 & & 289 & \\
\hline adstone..... & 17 & & 306 & \\
\hline tone and & 2 & & 308 & \\
\hline 3. Fire clay ............ & & 4 & 311 & \\
\hline $\begin{array}{l}\text { Sandstone.. } \\
\text { Clay shale.. }\end{array}$ & 2 & 8 & 313 & \\
\hline & & & & \\
\hline
\end{tabular}

CHELTENHAM FIRE CLAY.

Of the beds named in the above sections, a few are relatively persistent and may be traced with some certainty over considerable areas. Foremost among these is the bed of fire clay known as the Cheltenham. The equivalent of this bed on the east side of the Mississippi is not known, but on the Missouri side it underlies the western half of St. Louis and occurs also in the vicinity of Creve Cœur Lake and on the west bank of the Mississippi north of Baden, on the northern edge of the area mapped. Probably it underlies large areas between the places named, though its character there is uncertain. It is near the base of the series, the only intervening beds known being a thin pyritiferous or ferruginous sandstone and a limestone (probably thin) containing red cherts. The thickness of the fire clay ranges from $2 \frac{1}{2}$ to 12 feet. Almost everywhere it is overlain by 2 to 8 feet of shaly sandstone, generally micaceous. There are local coal blossoms near the contact of sandstone and fire clay.

SANDSTONES.

The ferruginous or pyritiferous sandstone beneath the Cheltenham fire clay occupies the same position with reference to the Mississippian limestone and the coal measures as that of the Chester group. This position may suggest their identity, but considering the overlapping character of both the Chester and the Pennsylvanian coal 
measures in a northwesterly direction, the late Mississippian age of this ferruginous sandstone seems highly improbable. In the absence of fossil evidence it has seemed preferable to regard this sandstone as the initial deposit of the Pennsylvanian overlap.

From 100 to 120 feet above the base of the Pennsylvanian on the Missouri side of the river is a sandstone which is somewhat continuous, ranging in thickness from a few feet up to 200 feet. The stone is characteristically yellow or brown, micaceous, rather soft, and in places coarse-grained, also cross-bedded. Swallow, who divided the coal measures of Missouri into three parts ${ }^{a}$ assigned to this micaceous sandstone the topmost place in his Lower Coal Series. (See section, p. 27.) Within the St. Louis area it is not known to be fossiliferous, but elsewhere, according to Swallow, its lower beds abound in Calamites, Sigillaria, and Lepidodendra. This sandstone is not present in the immediate vicinity of St. Louis, having doubtless been eroded. It is, however, found at Ramona Park and Jennings Heights, a few miles to the north, and at various other places along the northern boundary of the area, where it has a thickness of approximately 20 feet.

The equivalent of this sandstone on the Illinois side is not determined. A similar stratum is shown in the Belleville section, 143 feet above the supposed base of the Pennsylvanian, but the section below it does not resemble that of the lower Pennsylvanian on the Missouri side, and the two sections may or may not be equivalent.

COAL.

Two beds of coal west of the Mississippi are locally thick enough to be mined. These are Nos. 10 and 7 in the Cheltenham section (p. 25). The former is no doubt the same as No. 64 in Swallow's section (p. 27). The limestone underlying the coal, though locally (as in Swallow's section) separated from it by a thin bed of shale, is widely developed and serves to mark the horizon of the coal.

The lower bed (No. 7 in the Cheltenham section) is even thinner and more local than the upper bed. Bed No. 4 in the vicinity of St. Louis is generally a mere streak. Reference to Swallow's section will show that farther west the coal beds not far above the basal fire clay are not only thicker but more numerous.

East of the Mississippi the lowest coal of which there is any mention is No. 8 in the section near Collinsville (p. 28). This is probably from 150 to 200 feet above the base of the Pennsylvanian. The principal (Belleville) bed is a little more than 100 feet higher. The thickness of the lower and barren beds on the east side of the river is no doubt greater than on the west, but there is no evidence from this area that the Illinois coal beds correspond to those in Missouri. 
The Belleville bed was in the early Illinois reports termed No. $1 \mathrm{C}$ (later No. 6) and its recognition over a wide area was assumed. Within 50 feet or more below it two other continuous beds known as $1 \mathrm{~B}$ and $1 \mathrm{~A}$ (Alton bed) were assumed to exist. It is not probable that these correspond to those mentioned as Nos. 16 and 8 in the section near Collinsville. In the present state of knowledge of the coals of this region all such long-distance correlations are of questionable value.

\section{TERTIARY SYSTEM.}

LAFAYETTE GRAVEL.

Composition.-At various places west of St. Louis on the higher parts of the upland are deposits of gravel whose character corresponds in general to that of the recognized Lafayette gravel of the Gulf and Atlantic Coastal- Plain. The patches of gravel here preserved are believed to represent the same formation. ${ }^{a}$ (See Pl. V, B.) The material of the gravel is largely chert, but it contains also pebbles of vein quartz, quartzite, and jasper. Some of the quartzite pebbles are of a purplish color and closely resemble the Baraboo quartzite of Wisconsin and the Sioux quartzite of Iowa and South Dakota. Many of the jasper pebbles strongly suggest the jaspilites of the Lake Superior region. The constituent stones of this gravel are characteristically rounded, the cherts being most angular, but even these being probably as much rounded as their brittleness will allow. The average size is perhaps not greater than that of a walnut, though locally the gravel is coarser and individual bowlders of quartzite may weigh 50 pounds or more.

An almost constant attendant of these gravels is a highly ferruginous sandy loam, generally of a bright orange or brown color and, although in appearance almost a pure sand, containing enough clay to make the mass plastic. In some places this loam occupies a position above the gravel, as at Grover, $2 \frac{1}{2}$ miles north of Glencoe, in the O'Fallon quadrangle, adjoining the St. Louis quadrangle on the west; in others it is interbedded, as at the banks 2 miles farther west. Thinner beds of light-colored plastic clay occur here and there, some of them broken into angular blocks whose surfaces have the almost omnipresent ferruginous stain. The whole formation is in different places clearly bedded, cross-bedded, or thoroughly unassorted. The observed thickness is nowhere more than 30 feet. The gravels rest directly on the Carboniferous or, farther west, on older rocks. Whereever found in the St. Louis quadrangle they are covered by loess. This is likewise the case 2 miles south of Pacific Junction, 34 miles west of St. Louis, but near Ballwin, in the O'Fallon quadrangle, they cap a high hill on which no loess is found.

\footnotetext{
$a$ This is the opinion of W J McGee and R. D. Salisbury, both of whom are familiar with the Lafayette of the Coastal Plain and accompanied the writer in visits to the exposures west of St. Louis.
} 


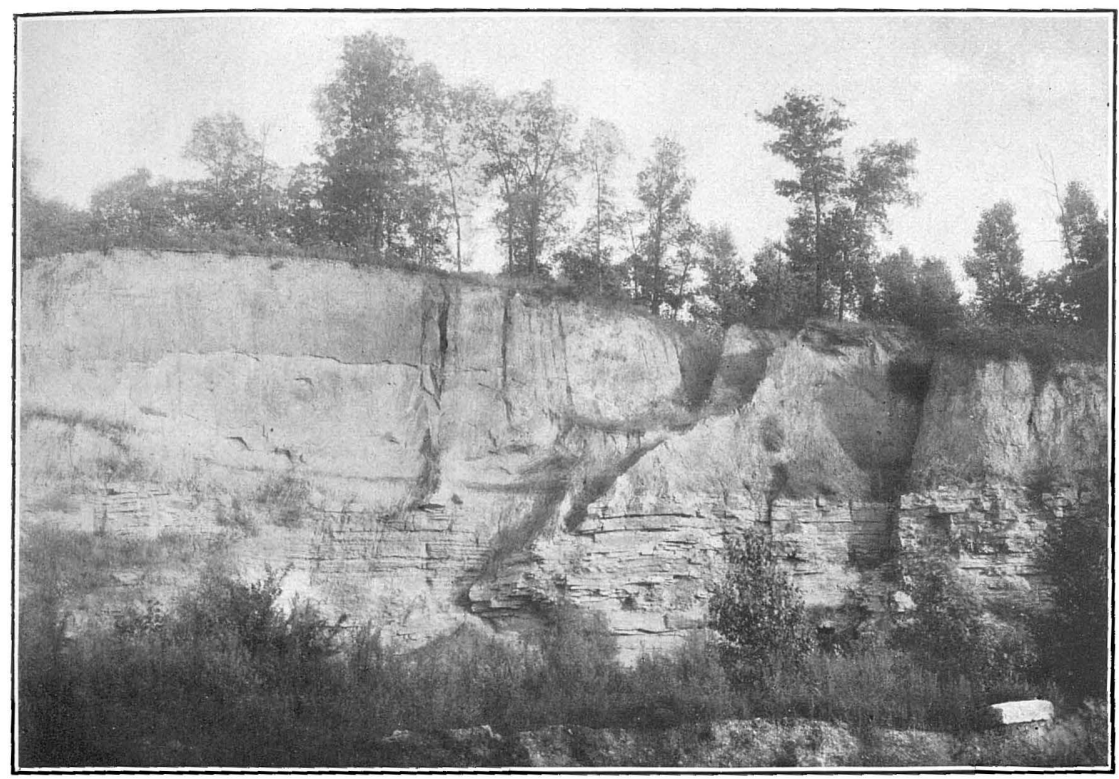

A, LOESS ON ST. LOUIS LIMESTONE ONE-HALF MILE SOUTH OF STOLLE, ILL.

(See pages 23,33.)

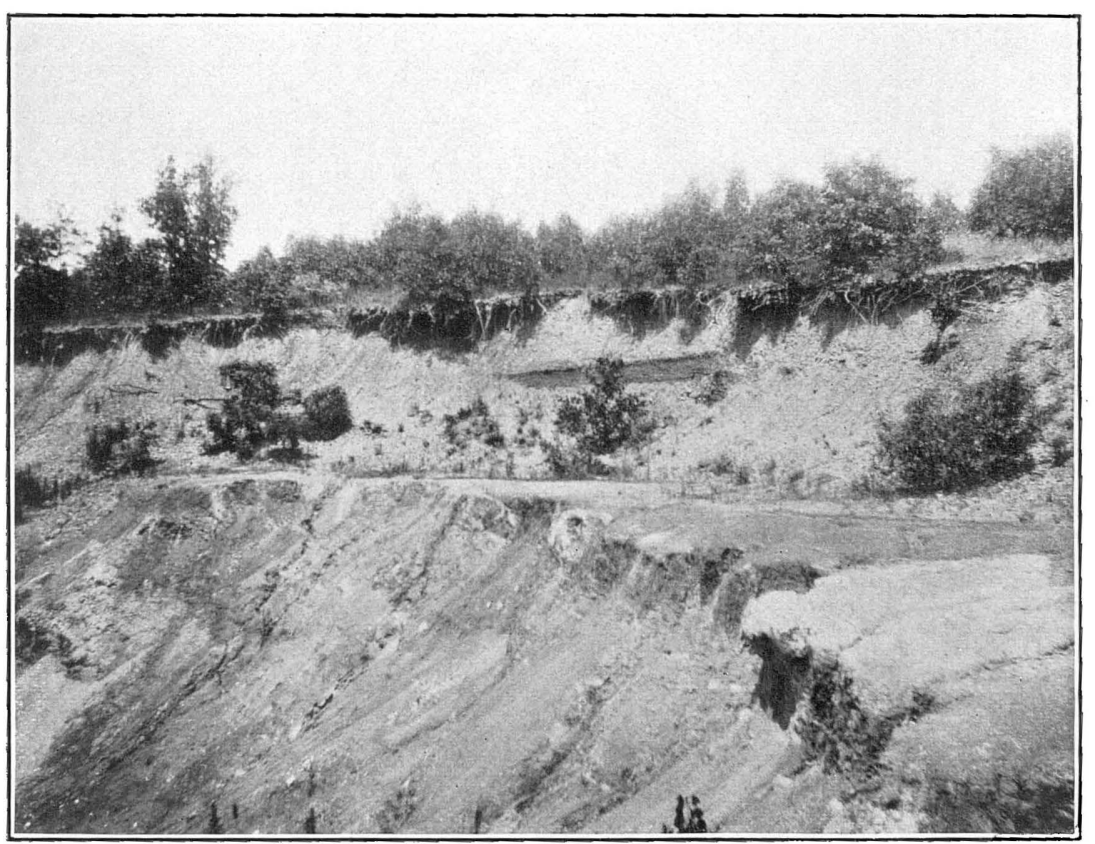

B. LAFAYETTE GRAVEL ON CARBONIFEROUS SHALE NORTHWEST OF GLENCOE, MO.

The gravel is interstratified with loamy sand which appears dark in the picture. (See page 30.) 

Topographic position.-Topographically these gravels occur on the higher and least eroded remnants of the upland. They may be found at lower levels, though perhaps in a more or less worked over or redeposited condition. At Webster Groves, near the St. Louis and San Francisco Railroad station, they are at a height of 620 feet or more. On the Creve Cœur electric line northwest of Elmwood Park a considerable area over 700 feet high, and therefore slightly above the general level of the upland, is apparently underlain by these gravels, though the thick covering of loess prevents good exposures and, except in wells, the gravel is found only in a redeposited form. The same is true of the high area at Stratmann.

The best exposures of the Lafayette are found in the O'Fallon quadrangle. Two miles northwest of Ballwin an isolated hill less than half a mile wide at the base rises to an elevation of more than 750 feet, being at least 50 feet higher than the surrounding upland. This hill is capped with about 30 feet of gravel, near the base of which issue springs. The excellent exposures at and west of Grover are on the remnant of upland, above 750 feet in height, which divides the waters flowing northward to the Missouri from those flowing southward to the Meramec. At a point 2 miles south of Pacific Junction another deposit is present in the Meramec Valley at a much lower level than those farther east, despite the general rise of the upland toward the west. The top of this deposit is not more than 500 feet above the sea and it constitutes a terrace in the present valley of the Meramec. It is possible that this material represents a redeposition of the Lafayette gravel, but in all physical characteristics it is identical with the Lafayette and there is no reason except its topographic position to assume a working over of the materials. (See p. 45.) The gravel at this place is almost exclusively chert, but includes a few. pebbles of quartzitic sandstone.

\section{QUATERNARY SYSTEM. \\ PLEISTOCENE DEPOSITS.}

The vicinity of St. Louis is a somewhat critical locality with respect to Pleistocene deposits. It apparently contains the thin edge of the Kansan drift sheet, which came from the northwest, and that of the Illinoian drift, which came from the northeast. Loess covers the entire area embraced in this study.

\section{KANSAN DRIFT.}

At several points near the northern margin of the area are exposures of sand or gravel composed in part of igneous particles whose appearance suggests the Kansan drift as known elsewhere. The prominent characteristics of these sands and gravels are the extreme oxidation of the ferromagnesian minerals and the complete kaolinization of the feldspars. In the disintegrated remains of such minerals 74449 ${ }^{\circ}-$ Bull. 438-11- 3 
are embedded the quartz granules of the original rock particles. An exposure of such material is seen in the west bluff of the Mississippi about a mile south of the Chain of Rocks (which is just north of the area mapped), at an altitude between 480 and 500 feet. Two miles north of the Chain of Rocks, in the gorge of a small stream, is a similarly old and weathered deposit at an altitude of about 450 feet. This deposit is of coarser gravel than that above mentioned, but does not contain bowlders. It is overlain by a few feet of dark-colored plastic clay and this again by drift believed to be of Illinoian age.

In the bank of Watkins Creek, about 1 mile west of the Chain of Rocks and at an altitude probably as low as 430 feet, or only 30 feet above the average level of the Mississippi, is an exposure of 20 feet of very much weathered gravel similar to that above described, but containing in addition many pebbles plainly derived from the Lafayette. These are quarti, quartzite, jasper, and chert, the last commonly weathered to the familiar chalky white appearance. Dark-colored rocks are very sparingly preserved, and there are relatively few pebbles of granite and pegmatite. The preservation, however, of even a few igneous pebbles in recognizable condition differentiates this deposit from those mentioned above and it is possibly younger. It is overlain by a partly consolidated silt, inclosing pebbles similar to those. below but less weathered, and this again by 20 or 30 feet of loess.

It can not be definitely affirmed that any of the deposits here enumerated as of probable Kansan age are ice laid. That on Watkins Creek was almost surely deposited by water and the others may have been.

\section{ILLINOIAN DRIFT.}

Glacial drift which is much less weathered than that described above is found at various places in and near the area here treated. The upper deposit mentioned as occurring 2 miles north of Chain of Rocks is of this character. It contains some fair-sized bowlders or fragments of local limestone, which favor the hypothesis that it is an ice-laid deposit. Bowlder clay is found beneath the loess at various places in St. Liouis, some of them as much as 4 miles west of the Mississippi. In this clay are foreign bowlders up to 1 foot in diameter. South of Jefferson Barracks the bedrock is at places planed and striated. ${ }^{a}$

$a$ J. A. Drushell, of the Teachers College, St. Louis, has discovered a number of these exposures. Some of them he has described in Jour. Geology, vol. 16, 1908, pp. 493-498; others in personal letters to the author.

H. A. Wheeler (Trans. St. Louis Acad. Sci., vol. 7, pt. 3, 1905, p. 121) describes the occurrence of a typical bowlder clay encountered in digging a tunnel under Pine street and Taylor avenue. Various igneous rocks which are common in the northern drift are enumerated.

J. E. Todd (Missouri Geol. Survey, vol. 10, p. 162) describes a cut which disclosed beneath the loess 8 feet of "bowldery clay or till" in which a few igneous bowlders were found, though most were fragments of limestone.

G. Frederick Wright noted near Forest Park striated pebbles ranging in size up to 3 inches and some thin limestone chips striated on one side only, perhaps broken from bedrock, and, if so, evidently not transported far.

A. H. Worthen (Geol. Survey Illinois, vol. 1, 1866, p. 314) speaks of " 15 feet of common chocolate-colored brown drift clay" exposed in a mound in the northern part of the city, though his language elsewhere does not indicate a sharp distinction among the various classes of surficial deposit known as drift. 
East of the river undoubted till of Illinoian age is exposed near Edwardsville, a few miles northeast of the area here mapped. Within the area there are, in the face of the bluff or the ravines which indent it, scattered exposures of glacial drift.

LOESS.

Loess covers all the uplands of this area. Most of the loess on the bluffs has the typical character, which has been so frequently described as to make repetition unnecessary. Calcareous concretions, many of them large and branching, and pulmonate shells are abundant. (See Pl. V. A.)

In places the formation is entirely without stratification; elsewhere the typical bluff loess is interstratified with silt or fine sand. Here and there occur thin laminæ of dense clay and horizontal bands of a limonitic crust. The loess is thickest on the east bluffs of Mississippi and Missouri rivers, where, in some places, it is 50 feet thick. Its thickness decreases with increasing distance from the great rivers, averaging 10 or 15 feet at a distance of a very few miles. On the steepest slopes of the Meramec Valley it is generally absent.

Back from the bluffs the loess becomes more clayey. Over most of southern Illinois it is known as the "white clay." What seems to be an extension of the same formation in the Gulf States is known as "brown loam." Every part of the area here treated is so near to the great rivers that these more clayey varieties are not typically exemplified, but a tendency in their direction is clearly observed.

Among the departures from the typical bluff loess character the most noteworthy is a phase of ashy color and generally more silty constitution, in many places showing distinct lamination, but locally interspersed with the typical bluff loess in forms defying generalization. In a large way this aberrant type occupies lower levels, in many places underlying that of the more familiar type and here and there constituting stream terraces, as on the north side of River Des Peres at Carondelet.

The upper 4 or 5 feet of the loess, just beneath the soil, is clayey. It is distinguished by brickmakers from the more mealy material beneath as the "strong clay." This surface phase is apparently due to weathering. Where the loess rests on limestone it commonly shows near its base the effect of admixture with the residual clay of the limestone. This is evident in its generally more reddish color and its greater tenacity. Corresponding effects may be observed where. the loess rests directly on the chocolate-colored shales of the Pennsylvanian. In either case some gradation is generally apparent.

In many places a zone of several feet at the base of the loess contains much gravel. The constituent stones are the same as those of 
the till. In the western part of the area many quartz, quartzite, and chert pebbles appear to have been derived from the Lafayette.

A generalized section of the loess is as follows:

Soil.

Section of loess in St. Louis quadrangle.

Clayey loess-the "strong clay" of the brickmakers.

Typical bluff loess.

Basal portion, locally mixed with residual clay and drift gravels.

RECENT DEPOSITS.

Alluvium of the flood plain.-The flood plain of the Mississippi is composed of 60 to 150 feet or more of alluvium superimposed upon the Mississippian and Pennsylvanian beds. Similar alluvium occupies the valley of the Missouri and a thinner sheet is present along the Meramec and some smaller streams.

In general, the upper 10 or 15 feet of the alluvium is composed in great part of clay and silts of various grades of fineness. These materials are in large measure deposits from suspension in flood waters and are as a rule clearly laminated. Below a depth of 10 to 15 feet the material is prevailingly sand with minor lenses of clay and gravel to a depth of 60 to 90 feet where best known, and possibly to a much greater depth elsewhere. This is chiefly the material deposited on the inside of meander curves and in bars, regardless of overflow, and has in the main been brought to its present position by being urged along the bottom rather than by being carried in suspension.

At depths ranging from 60 to 90 feet where borings are most numerous there is commonly found a coarse gravel which rests upon the bedrock and has a thickness of 10 or 20 feet or even more. This bed is in places composed of cobblestones or even bowlders. This material is continuous beneath the present channel and is moved forward only in extreme floods which scour the channel to bedrock. During the subsidence of the flood the heaviest stones, being the first to come to rest, are left in disproportionate numbers at the bottom. So far as is known, even where the bedrock lies deepest this relation of coarse gravel below and sands above exists. Where the surface of the bedrock lies the deepest the stones of the overlying gravel are the smallest.

Terraces.-Alluvial terraces within the area studied are generally insignificant and are incident to recent meanders. . In the notches of the bluff through which certain of the smaller streams emerge there are some remnants of terraces ranging in height between 40 and 80 feet above the great streams at their nearest points. The larger number differ little from 60 feet in height. They are almost universally composed of loess, generally stratified and in places suggesting 
by its impure character that it has been washed from the neighboring uplands and redeposited. All the material of these terraces may have been similarly redeposited. At one place only, on Feefee Creek near the point where it emerges from the Missouri bluff, such a terrace contains beds of gravel, evidently of glacial origin. About 1 mile south of Chain of Rocks a deposit of fresh-looking sand of glacial origin lies against the west bluff of the Mississippi at a height of approximately 60 feet above the river.

It is not impossible that most of these terraces should be correlated and explained as representing the somewhat aggraded flood-plain levels during the Wisconsin ice epoch, but conclusive evidence is lacking.

\section{STRUCTURAL GEOLOGY.}

REGIONAL DIP.

The broad structural features of the area are revealed by an inspection of the geologic map. Unconformities of angle being relatively small, the appearance of coal measures in the north and east and of the lower Mississippian formations in the southwest corner indicates a general northeastward dip - that is, away from the Ozark structural dome and toward the synclinal basin of central Illinois. The structural section shown in Plate VI, $B$, is constructed from outcrops and wells ranged in an almost straight line from Pacific, which is 32 miles in a direct line west-southwest of St. Louis, to Monks Mound, which is 8 miles east-northeast. In this distance of 40 miles the top of the St. Peter declines in altitude from about 550 feet above sea level to 1,540 feet below, an average fall of $52 \frac{1}{2}$ feet to the mile. Plate VI, $A$, is a similar section showing dips in a north-northeasterly direction from Crystal City by way of Monks Mound to the Keller oil well, about 2 miles south of Peters station, near the northeast corner of the area. From Crystal City to Monks Mound, a distance of 34 miles, the fall of the upper surface of the St. Peter sandstone is 2,040 feet, an average of 60 feet to the mile. This being the largest dip known for a long distance, it may be taken provisionally as the true dip for strata lower than the Pennsylvanian. Little is known, however, of a possible eastward dip of these strata beyond the Illinois bluffs.

In the northern part of the area traversed by section $A$ in Plate VI, the Pennsylvanian has a much smaller dip than the lower series in the direction represented by the section. The decline of the Belleville coal seam in this direction is represented by the line $A-B$ in the section. Its easterly dip is here much stronger than the northerly dip, the altitude of this seam at Belleville being but 380 feet, whereas in the bluffs near Centerville it is above 500 feet. Whether this represents a difference in direction of dip between the Pennsylvanian and Mississippian rocks can not be determined until more is 
known of the true dip of the Mississippian. At all events, there is in the direction represented by the section a progressive overlap of Pennsylvanian beds toward the southwest as the Ozark highland is approached.

\section{LOCAL TRANSVERSE FOLDS.}

The general northeasterly dip is locally interrupted by at least one minor fold, the direction of whose axis is north-northwest. (See $\mathrm{Pl}$. VI, $\dot{B}$.) This fold is observable in the west bluff of the Mississippi, the axis of the anticline passing approximately through the Workhouse quarry, opposite the north end of Arsenal Island. It extends thence west of north past the Compton Hill reservoir and dies out in the vicinity of the Grand Avenue viaduct. It is revealed near that place by at least three deep wells and a group of quarries. The amount of local uplift indicated by the log of a deep well at Tamm's glue factory is fully 200 feet. This is near the north end of the anticline, where its height is reduced by a rather sudden pitch. It is quite probable that this fold is continuous across the Mississippi into St. Clair County, Ill. Its extent there is unknown because of the deep mantle of drift. $^{a}$ A detailed section along the line represented in Plate VI, $B$, would show much variation in steepness of dip and probably other local anticlines similar to the one shown in the figure. There is, for example, a suggestion of a similar and parallel fold, or at least an arrest of the general northeasterly dip, along the line of River Des Peres about 5 miles farther west.

So far as folds of this smaller order are concerned, no discrepancy of angle has been observed between the Pennsylvanian and Mississippian strata. The presence of the former in the Cheltenham syncline likewise seems to indicate that the minor deformation, at least, was accomplished after Pennsylvanian time.

\section{GEOLOGIC HISTORY.}

Little can be known from data obtainable within this area of its history previous to the Carboniferous period. The only sources of information are well borings. These, however, indicate the presence of strata which are well known elsewhere in the Ozark region and whose history is to some extent understood. From the presence of these rocks it is safely inferred that the geologic history of the St. Louis area before Carboniferous time corresponds to that of the northeast slope of the Ozark uplift as inferred from the strata which outcrop on its slopes. In interpreting the events of this locality in the light of the provincial history it is remembered that the St. Louis area is far out on the edges of the slope and was accordingly beneath the sea a larger share of the time than the localities to the west and south.

$a$ Weller, Stuart, Geological structure of the State: Bull. Illinois Geol. Survey No. 2, 1906, p. 22. 



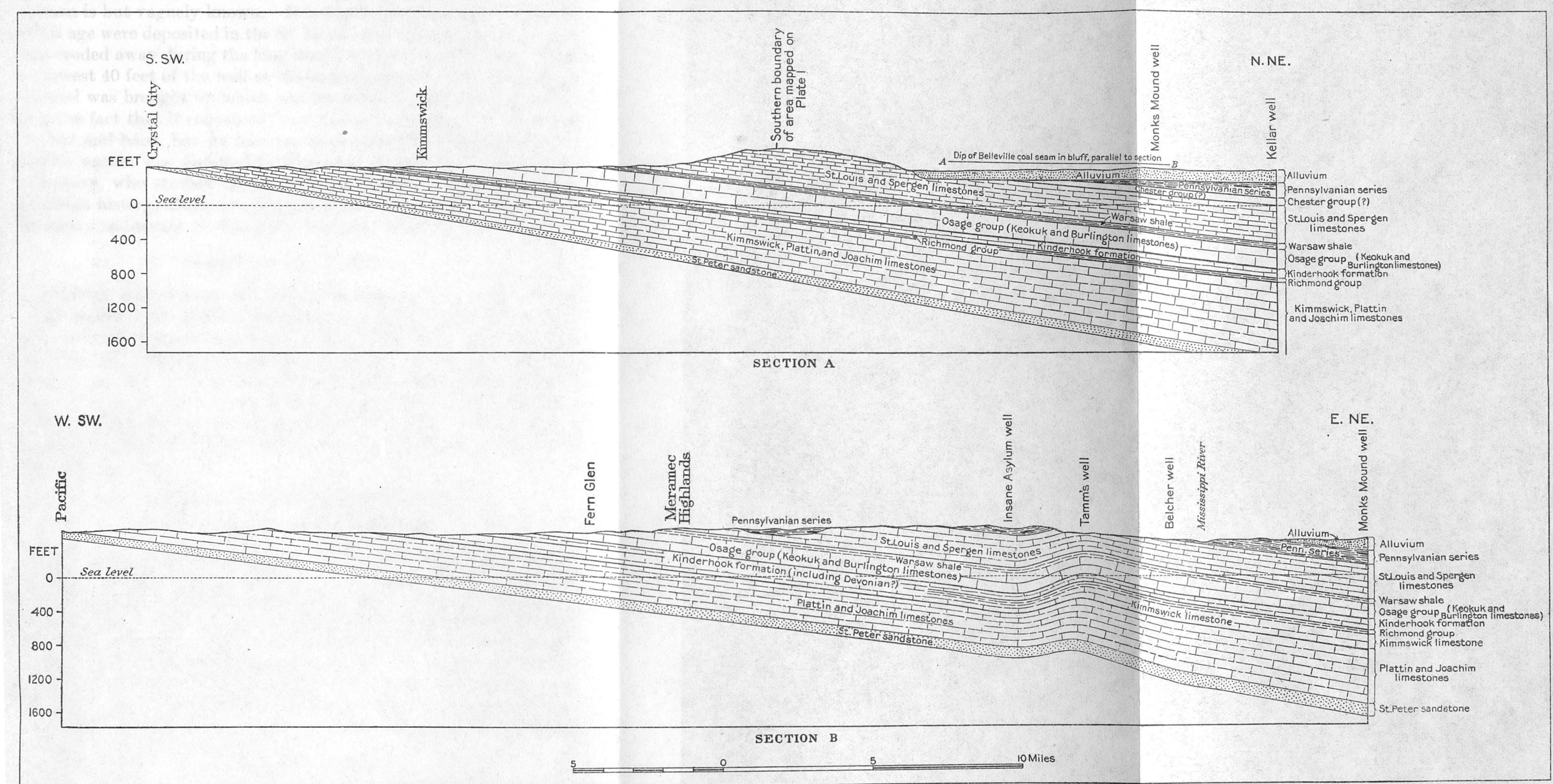

STRUCTURE SECTIONS: A, FROM CRYSTAL CITY, MO., TO POINT NEAR PETERS STATION, ILL.; B, FROM PACIFIC, MO., TO MONKS MOUND, ILL. 

ALGONKIAN TIME.

At some time during the Algonkian period the Ozark region may have been beneath the sea and receiving sediments from lands whose location is but vaguely known. It is highly probable that sediments of this age were deposited in the St. Louis area, though they may have been eroded away during the long land period which followed. From the lowest 40 feet of the well at the insane asylum (3,843.5 feet deep) material was brought up which was recorded as "powdered granite" from the fact that it contained "red quartz or feldspar." a The rock was red and hard, but its features were evidently indecisive and its granitic nature was disputed by Professor Hambach, of Washington University, who studied all the samples carefully. The bit of preCambrian history, therefore, depending on the presence or absence of Algonkian sediments at this place remains unknown.

\section{CAMBRIAN LAND INTERVAL.}

Cambrian sediments do not appear in Missouri before the middle of the period, their absence indicating a long period of land conditions perhaps embracing a large part of Algonkian time. During this time any Algonkian sediments must have been in large part washed into the sea and the Archean below still further wasted. Along with the wasting of the land by erosion there was doubtless a gradual settling down and surely a rising of the sea level, so that in Middle Cambrian time the Ozark region, and with it the St. Louis area, became submerged.

\section{CAMBRO-ORDOVICIAN SEDIMENTATION.}

\section{FORMATION OF MAGNESIAN LIMESTONE.}

From this time to the close of the Ordovician period the slopes of the Ozark were submerged almost continuously, though occasional minor uplifts exposed them to surface erosion. During most of this time the shore was so remote or the land so low that there was but little terrigenous sediment to accumulate on the bottom or mingle with the constantly deepening calcareous ooze which was subsequently consolidated into magnesian limestone. During the continuance of such conditions nearly 3,000 feet of sediment slowly accumulated in the St. Louis area, more than three-fourths of which is limestone.

SANDSTONE MAKING.

At intervals temporary uplifts of the Ozark and more distant lands steepened the stream profiles and gave new impetus to erosion and transportation, at the same time narrowing and probably shallowing the seas so that beds of sand were laid down. The occurrence of such

a Broadhead, G. C., On the well at the insane asylum, St. Louis County: Trans. St. Louis Acad. Sci., vol. 3, 1873, p. 218. 
conditions on a very small scale was frequent, but there were four epochs during which the effect was especially noteworthy, the resulting sandstones being widespread and ranging in thickness from 50 to 300 feet.

The first of these four sandstone-making epochs was the later Cambrian and the last was the St. Peter. ${ }^{a}$ At the beginning of the St. Peter epoch a very broad area was out of water, as is known from the eroded surface of the magnesian limestone below. Locally at least, and probably over much of the Ozark region, ${ }^{b}$ the St. Peter sands were themselves exposed to surface erosion before the overlying limestones were deposited. At Pacific an unconformity of angle amounting to $10^{\circ}$ or $15^{\circ}$ indicates considerable crustal movement attending the land interval which followed the St. Peter. (See Pl. III, A.)

This epoch is remarkable as one of clear seas in which a moderate amount of sand and but very little mud were delivered to the sea. The unusual roundness of the sand grains indicates that they had been much handled by wind on the beach before submergence. They were then washed over and over by the waves until all finer material was carried away in suspension. The resulting deposit offered to the subsequently percolating water little silica in soluble form, and is therefore poorly cemented. Moreover, the extraordinary roundness of grain adds to the weakness of the poorly cemented stone.

It may be that the distinguishing process of St. Peter time--namely, the thorough rounding of the sands by wind and.assortment by waterwas not carried on along a single shore line from which the sands of the entire formation were derived, but that this shore line advanced across the area with the gradual submergence of the land, and that therefore the exact age of the formation varies from place to place. There is nothing to show that the entire Ozark region was ever covered by these sands, hence the St. Francis Mountains may have remained a source of sediment throughout the epoch.

\section{MIDDLE ORDOVICIAN EPOCH.}

The broad, clear, and perhaps deeper seas which followed the St. Peter in the Joachim, Plattin, and Kimmswick epochs differed little from those of preceding limestone-making epochs, but, whether from a difference in conditions at that time or subsequently, the limestone which accumulated in the later epochs contains less magnesia, being in part an almost pure carbonate of lime.

The exact extent to which these and the preceding seas and their sediments covered the Ozark highland is not determined. Opportunities for subsequent erosion have been so great that complete removal of thick strata would not be surprising.

\footnotetext{
$a$ It should be noted that these four limestones and four sandstones are frequently known by number, beginning at the top, so that th $\cdot$ St. Peter is, in the older publications, commonly called the "First" sandstone. (See geologic column, pp. 13-14, also well section, pp. 16-17.)

$b$ Broadhead, G. C., Geological history of the Missouri Paleozoic: Am. Geologist, vol. 14, 1894, p. 384.
} 
LATE ORDOVICIAN SHALE MAKING.

Following the middle Ordovician and including a long period of land conditions came a gentle rise of the Ozark area which enabled the streams to bring down to the sea some of the residual clays and muds that had been long accumulating on the land while the land was low, the streams sluggish, and the seas almost free from terrigenous sediment. The accumulation of this mud made the shales of the late Ordovician, represented by the Maquoketa shale near Kimmswick. These deposits may have been much thicker than the remnants now seen, for they were in part carried away as the result of the continued uplift which exposed them to erosion. It is now known that the seas of this epoch and the preceding middle Ordovician were continuous to the west beyond the middle of the State. ${ }^{a}$

\section{SLLURIAN-DEVONIAN LAND PERIOD.}

During the Silurian period the Missouri land was higher and broader than in the preceding periods, the shore probably being a little northeast of the site of St. Louis, though at the time of broadest Silurian seas the shore was probably curved round the Ozark Island and was not far distant from the area here considered. If this area was at any time submerged, the accumulated sediments were eroded away before the deposition of the Carboniferous beds.

If at any time during the Devonian period the seas covered the site of St. Louis, the sediments of such time were muds which have been consolidated into shales not now clearly distinguished from those of the Ordovician below and the Carboniferous above or have been removed by erosion. Such shales are discovered only in wells and do not contain recognizable fossils. (See pp. 14-18.) During the early Devonian the sea on the east seems not to have come farther west than the foot of the eastern slope of the Ozark, and the sea on the west communicating with the Pacific was far removed. Later these two seas came very near together. Strata deposited in the eastern sea are present along the Mississippi a short distance southeast of St. Louis and others whose fossils show that they were laid down in the western sea occur a few miles west and north of St. Louis, along Missouri and Mississippi rivers. The isthmus separating the two seas and connecting the land in Missouri and the Southwest with that in Wisconsin and farther north seems therefore to have embraced the area treated in this report. In late Devonian time this isthmus was in the main submerged and if the shales pierced by deep wells are indeed Devonian they probably belong to this epoch of submergence in the later part of the period.

$a$ Broadhead, G. C., Geological history of the Missouri Paleozoic: Am. Geologist, vol. 14, 1894 , p. 384. 


\section{CARBONIFEROUS SEDIMENTATION.}

MISSISSIPPIAN TIME.

KINDERHOOK EPOCH.

With the beginning of the Carboniferous the Ozark land area, which had persisted throughout Silurian and Devonian time, began again to be depressed. Within the St. Louis quadrangle it was borne downward as it had been borne upward, with little or no folding. The shales of the late Ordovician were brought again into essentially the position from which they had been lifted up. Though their thickness preserved is small, the area over which they remain is large. From similar evidence it appears that the land over which the early Carboniferous sea advanced was in this vicinity one of small relief. However, relief was not entirely lacking on the pre-Carboniferous land, and as a result the invading sea was locally and temporarily quiet and free from terrigenous sediments, while elsewhere it was probably shallower and more agitated and received deposits of sand. These conditions are reflected in the distribution of thin and local limestones and sandstones like the Glen Park and Bushberg members of the Kinderhook formation. (See pp. 19-20.)

The first deposit of wide extent in the advancing Carboniferous sea was one of shale and shaly limestone having a reddish color, the Fern Glen limestone member of the Kinderhook formation. This color may be due to the long exposure and thorough oxidation of the mantle rock during the Silurian and Devonian land interval. The surface materials thus exposed and oxidized became a source of the early Carboniferous sediments.

$$
\text { OSAGE EPOCH. }
$$

The passing of the Kinderhook epoch into the Osage was marked by a diminution of muddy sediment from the land and a disappearance of the red color of the sediments. Marine conditions and sedimentation were uninterrupted during the deposition of the several hundred feet of limestone marked by Burlington and Keokuk faunas. Some time before the end of the Osage the Spergen fauna (pp. 23, 41), which was already flourishing elsewhere, made an incursion into this territory and left its remains in a 2 or 3 foot bed of limestone about 50 feet below the summit of the Keokuk. Conditions quickly reverted, however, the Spergen fauna disappearing.

The ooze of this epoch, or the water circulating through it both during its deposition and later, contained an extraordinary amount of silica in soluble form, probably derived from siliceous skeletons. This silica aggregated in the form of chert. ${ }^{a}$ Doubtless some strata

$a$ A study of the cherts of the limestones of Missouri has been made by E. O. Hovey, who has also reviewed the theories of their origin. See Missouri Geol. Survey, vol. 7, pt. 2, 1894, pp. 727-739. 
were richer in this substance than others when the deposit was made, but transfer and substitution of material by ground waters probably made these strata even richer in silica while removing their lime carbonate. As a rule this work of ground waters in aggregating the silica at one place is made apparent by a nodular or concretionary form. Between the continuous band or bed and the isolated nodular concretion there are all gradations.

WARSAW EPOCH.

At the close of the Osage and the beginning of the Warsaw a moderate rise of the land caused mud to be again washed down into the sea. At intervals this mud greatly predominated over the calcareous ooze which continued to accumulate. The resulting Warsaw formation is therefore in large part shale. At certain intervals when the sea was clearer animal life was very abundant.

SPERGEN EPOCH.

The continued wearing down of the land, aided perhaps by slight depression, caused a dominance of limestone making again in Spergen time, though locally and at intervals mud continued to accumulate. That the waters were shallow even during the deposition of limy ooze is plain from the clearly marked and abundant cross-bedding of the limestones. That terrigenous sediments should be absent from such shallow waters indicates that the land was very low.

The shallowness and doubtless the warmth of Spergen waters made this epoch very favorable to life. Moreover, the same conditions were uniform over wide areas, for assemblages of the same forms prevailed at widely separated places. A collection of Spergen forms from the Meramec Valley would be very similar to a collection from Spergen Hill, Ind., where the life of this epoch has been studied in detail.

ST. LOUIS EPOCH.

The physical conditions prevailing in the Spergen epoch continued into the St. Louis epoch. As indicated by abundant cross-bedding and some beautiful ripple marks, the water continued shallow, though almost free from land-derived sediments. Parts of the formation abound in chert, indicating a revival of the conditions that gave the large silica content to the waters and ooze of the Osage sea.

Certain conditions not generally present in the preceding epochs caused in St. Louis time the accumulation of excessively fine calcareous mud which hardened into rock having the texture of lithographic stone. Chemical precipitation has been suggested to account for certain similar sediments elsewhere, but it is rather more probable that a slight emergence of the calcareous bottom from another portion of the St. Louis sea caused the sediment to be reassorted, its 
finer parts being carried to this area in suspension. In conformity with this supposition are the general thinness of the beds of this dense limestone and its interbedding at many places with very fine mud.

Not uncommonly the dense limestone of lithographic texture is found in small irregular bodies or lenses not larger than a man's hand, embedded in the coarser granular limestone of the ordinary type. The local brecciation of the dense limestone (see p. 24), as well as the faulting of chert bands, favors the supposition that these embedded bodies were consolidated earlier than the granular matrix, which shows no evidence whatever of deformation. No cause is suggested for such brecciation other than the slight movements incident to settling and crystallization. The movement, whatever its nature, did not affect the horizontality of the beds above and below.

CHESTER EPOCH.

The St. Louis epoch was followed by a very general shallowing of the Carboniferous sea and a broadening of the Ozark land, which caused sand to accumulate in and around the St. Louis area. This condition, accompanied by a change of fauna, marks the Chester epoch.

\section{MID-CARBONIFEROUS LAND EPOCH.}

The uplift which narrowed and shallowed the seas during Chester time foreshadowed the greater uplift at its close, whereby a large part of the area covered by the Mississippian sea became land and the strata were locally tilted and folded. With this rise of the land a part of the regional dip toward the northeast was imparted to the Mississippian strata of this area. Next came a long epoch during which the landward edges of the several Mississippian formations were beveled by erosion.' In this process the edge of the Chester, if that formation once covered the area here treated, was worn back to the northeast corner, the portion of the area to which the rocks of this age seem now confined.

\section{PENNSYLVANIAN TIME.}

When the land was again submerged it was subjected to those remarkable and exceptional conditions which prevailed at the beginning of the Pennsylvanian coal-making period. The general surface of the land was so nearly horizontal that swamps existed over very wide areas. The water of these swamps was fresh and the vegetation suited to it, but at intervals the continued or periodic sinking carried the surface below sea level, and shales, sandstones, or limestones which carry marine fossils were formed. In these swamps vegetation accumulated to form peat, which by subsequent burial and consolidation became coal.

Beneath a bed of peat, or even a sheet of swamp water which is charged with the organic acids that characterize peat, the alkaline 
constituents of a clay bed may be exhausted to neutralize such acids. The alkaline or metallic constituents in the clay act as fluxes, making the clay more fusible. The removal of the alkalies is therefore one important element in the origin of fire clay. Another is the removal of the iron by carbonation and solution. Both these processes are favored by swamp conditions. Such conditions caused the refractory character of the widespread clay bed known as the Cheltenham fire clay (pp. 28, 50). Locally there was a growth of vegetation and an accumulation of peat just above this clay. In such places the roots which entered the clay aided in extracting from it the constituents that act as fluxes, most of which are also plant foods. Over most of this great bed, however, there is little or no coal; hence its refractory nature is not due to the action of roots but solely to leaching by swamp waters.

The sinking of the region during the coal-making period again greatly narrowed the land, if indeed this was not at times quite sub. merged. Remnants of sediments of this age are found high on the Ozark flanks, though the highest have not been shown to contain marine fossils and may therefore represent isolated basins which were not depressed to sea level. At some places these deposits rest directly on the magnesian limestones of the Cambro-Ordovician, thus overlapping the Mississippian limestones. It is probable, however, that the seas of Mississippian time were at least as widespread as those of the coal-making period, and that the Mississippian sediments were eroded during the land epoch which intervened.

\section{POST-CARBONIFEROUS UPLIFT AND PENEPLAIN.}

The great uplift which followed the coal-making period ended the marine history north and east of the Ozarks. Not only was the region elevated, but minor folding was produced. (See p. 36.) No record of the events of Mesozoic time is left in this region. Probably land conditions and erosion were general, but the process was no doubt one of varying rapidity. Warping may have been renewed at various times, and several cycles of erosion may have been approximately or locally completed. Evidence derived from the present topography shows simply that in relatively recent geologic time the entire Ozark area, together with the surrounding regions, was denuded to a peneplain. It is this peneplain whose fragments still remain as the upland that is visible in the sky line in all directions from St. Louis. (See p. 9.) Over wide areas it may be coincident with the upper surface of a resistant stratum which is nearly horizontal and which lay near base level when the peneplain was made. Elsewhere it may cut sharply across strata that are steeply upturned or bevel to a thin edge those which are gently inclined. The making of this peneplain appears to have been completed in Tertiary time. It is 
not improbable that the peneplain seen at St. Louis is a part of the one whose remnants are visible throughout the Ozarks.

Many parts of the United States are known to have undergone peneplanation in or about the Cretaceous period and to have been subsequently elevated and partly reduced to base level again before the close of Tertiary time. The absence of two peneplains in the northern Ozark region leads to the inference that if this region was base-leveled in Cretaceous time, the peneplain then produced was not uplifted, but remained approximately at base level until late in the Tertiary. ${ }^{a}$

\section{LAFAYETTE EPOCH.}

In the Pliocene period, when the land seems to have been for a long time at a low altitude as the result of denudation, a gentle upward crustal movement steepened the grades of some of the streams. These began thereupon to bring down pebbles which could not be transported by the sluggish streams on the old peneplain but which, being insoluble (see p. 30), failed to decompose and hence accumulated in the thickening mantle rock as the mud was gradually washed out. Stream-laid deposits of these pebbles seem to have been superimposed on local residual deposits. This gravel was accumulated near St. Louis to a depth of at least 30 feet.

This formation has sometimes been regarded as a marine deposit, a theory which, on the whole, is less satisfactory for this area than that stated above. 'The writer does not believe, however, that the study of the Lafayette remnants in this area is a sufficient basis for a comprehensive theory of the origin of this formation. The statements here made therefore apply only to the features of the formation in this locality. No theory is entirely without difficulties. The source of some of the constituent pebbles of the gravel is obscure. This is notably true of certain quartzites and jaspilites which resemble no known formation nearer than the Lake Superior region. Their transportation in large numbers for so great a distance would be remarkable, especially when it is remembered that some of them weigh more than 100 pounds. Streams can deposit sheets of gravel only when they are overloaded and, in extreme cases, branch out into distributaries as on an alluvial fan. ${ }^{b}$ The conditions for aggradation and the ability to transport such large stones are difficult to reconcile.

The occurrence of this gravel at an altitude of over 750 feet near Grover, 4 miles northwest of Glencoe, and again at less than 500 feet near Pacific, which is southwest of Grover, has an apparent bearing on its origin. If the gravel is a marine sediment it could not have

$a$ Compare Keyes, C. R., Composite genesis of the Arkansas Valley through the Ozark highland: Jour. Geology, vol. 9, 1901, p. 486.

b A conception of the manner in which the Lafayette gravel may have been deposited in extended sheets by rivers is given by Chamberlin and Salisbury (Geology, vol. 3, p. 305). 
been deposited in a layer of nearly uniform thickness at such diverse altitudes. Change of level by warping subsequent to sedimentation can not be invoked as an explanation, for the general level of the old peneplain, which antedated the gravel, still declines slightly to the east or northeast. It is possible to explain the deposition of the gravel by rivers by assuming that the several patches represent the simultaneous alluviation of independent valleys of different depths. This would imply, however, that the formation was made after the dissection of the peneplain - a theory that would involve grave difficulties. It remains to assume that the valley of the Meramec at Pacific is younger than the Lafayette gravel and that the apparent Lafayette sediments which constitute a terrace within it represent a redeposition of Lafayette material or are derived from a similar source at a later time. A second marine invasion can scarcely be supposed and the fluviatile origin of the deposit near Pacific is probably beyond question. Its significance consists in showing that the exact features of the typical Lafayette may be reproduced by stream deposition. The case is not essentially altered by assuming that the materials in question were derived from the original Lafayette. There is therefore no reason, so far as local evidence is concerned, for assigning different modes of deposition to the gravel at Pacific and that farther to the northeast and at a higher level.

\section{POST-PLIOCENE UPLIFT.}

After the making of the peneplain and the deposition of the Lafayette gravel the country was again uplifted. This uplift, like some of the preceding, renewed the dome in southern Missouri and tilted the peneplain in an easterly direction within the area studied. The valleys which now affect the underlying rocks beneath the glacial drift and loess were cut mainly since this last general uplift. Doubtless the altitude has varied somewhat since the rise of the land at or near the close of Pliocene time, but for the cutting of the rock valleys it is not necessary to assume that it has at any time been higher than at present.

\section{PRE-QUATERNARY DISSECTION.}

The courses of the streams which began work on the newly elevated land probably bore little resemblance to those which had baseleveled the country before the close of the Pliocene. The surface slopes of the Lafayette gravel controlled the smaller streams of the new systems. Percolation must have been very large, direct run-off small, and tributaries to the revived streams relatively few. Streams were, however, gradually elongated headward and tributaries became more numerous. Before the beginning of the glacial period this process had gone so far that the dissection was approximately mature, 
the original surface of the peneplain being only approximately preserved on the divides. During the same interval the channel of the Mississippi, which in Lafayette time must have been but little below the general surface, was cut almost to its present depth.

\section{GLACIAL HISTORY.}

KANSAN EPOCH.

The ice sheet of the Kansan epoch came from a northwesterly direction and in its extreme advance its front. stood in or near the area here described. No recognizable topographic effect of this occurrence remains, but the presence of Kansan drift, whether icelaid or water-laid, at an altitude of only 30 feet above the Mississippi is important in showing the depth to which the valley had been incised before that time.

\section{ILLINOIAN EPOCH.}

The Illinoian ice sheet came from the northeast, its front standing for a considerable time near the line of the Illinois bluffs. It seems to have crossed the river for a short time and doubtless left the small bodies of drift which have been found here and there beneath the loess in and near St. Louis. Like the older invasion, it left no recognizable topographic effects on the Missouri side of the river. On the Illinois side the glacial deposit is many feet thick in places, and has no doubt assisted in leveling the country by filling the preglacial valleys. Its real distribution is, however, obscured by the thick covering of loess. In fact, the amount of drift definitely known to be present within the area studied is insignificant.

\section{LOESS EPOCH.}

At some time after the deposition of the Illinoian drift, and possibly in connection with a succeeding pre-Wisconsin stage of glaciation, amounts of finely powdered rock flour hitherto unequaled were spread out by the combined agency of streams and winds. The greater thickness of this deposit near the great streams indicates that their agency was primary in transporting this fine silt; the manner of its distribution over hill and valley points to the work of the wind.

The vicinity of St. Louis exemplifies typically the distribution of the loess and therefore presumably also the manner of this distribution. Its thickness is greatest where it caps the bluffs and is greater on the east bluff than on the west. The extreme thickness is generally found within a small fraction of a mile from the edge of the bluff and in places reaches 50 feet or more. A mile farther from the river it is in most places but 10 or 20 feet thick, thus giving locally to the upland surface a slope of 30 or 40 feet away from the river within the first mile, This feature is conspicuous on the east bluff, 
not only within this area, but at numerous places from Iowa down to the Delta. On the west bluff this phenomenon is very inconspicuous.

This loess was doubtless brought down as mud suspended in the river. The loaded condition of the stream, implied in the handling of so much detritus, doubtless caused aggradation of its valley bottom. Under these circumstances floods must have habitually spread the fine detritus over the broad alluvial plain, leaving it to dry in the intervals between floods. Thence it was carried by winds over the uplands, the greater thickness on the east bluff being the result of the first settling from the prevailing westerly winds. In the East St. Louis district the loess on the bluff is thickest where the flood plain is widest, and it is possible that the greater thickness may result from the greater expanse of mud flat from which material was gathered.

Some of the loess that is clearly and minutely stratified or interlaminated with fine clay apparently still lies where it was originally laid down by the glacial stream. Other deposits similarly stratified may have been formed at the same time by side streams which washed back to the main valley the material carried by wind into their drainage basins. Still others are the work of later streams working on the original deposit. It is difficult to distinguish an original deposit of loess from one which has been worked over, and therefore it is not now possible to name any level beneath which the loess may have been deposited by streams and above which it must have an eolian origin. On the whole, distinct and horizontal stratification is found in the valleys of the great streams and at the lower levels.

\section{WISCONSIN EPOCH}

The Wisconsin stage of glaciation is represented in this area only by the materials which were washed outward from the glacier. They consist of small patches of sand and gravel, the freshness of whose minerals indicates relatively recent age. These deposits occur. in the Mississippi bluffs. From even the fragmentary data thus far obtained, it seems safe to assume that during the Wisconsin epoch the immediate valley of the Mississippi was aggraded to a height at least 30 or 40 feet above its present flood plain.

The terraces in the recesses of the bluffs where small streams emerge are composed almost entirely of loess, which, to judge from the topographic forms and from a local admixture of other material, may be supposed to have been gathered by the smaller streams from their basins and redeposited at the flood level of the larger stream. The highest remnants of such terraces are about 80 feet above the great rivers. It is not improbable that some of these represent the flood levels of the great streams in the Wisconsin epoch.

$74449^{\circ}-$ Bull. $438-11-4$ 
POSTGLACIAL EROSION.

STAGE OF DISSECTION.

The larger streams, including the Meramec and River Des Peres, and even some of smaller size have cut entirely through the loess mantle, so that their channels are on bedrock or recent alluvium. In the rest of the area, away from the immediate channels of the more active streams, the uniformity and continuity of the loess cover over hill and valley are remarkable. The smaller valleys still have loess bottoms, and the mantle may be thicker here than on the intervening hills. With the exception of the smallest valleys and recent gulleys, the location of the present drainage lines agrees essentially with that of their preloessal ancestors. It is certain that the loess never entirely filled the valleys of the former upland surface. It is fair to assume that the accumulation on the upland, where wind was the transporting agent, was so slow that contemporary run-off maintained in the most part the old drainage lines. Many of the smaller valleys were doubtless left deeper and steeper than they now are, subsequent creep having partly filled them and reduced their slopes. Where the drainage is at all active, however, the channels are progressively deepening and elongating headward while the side slopes have become steeper and convex upward; that is, their steepness increases as the stream is approached. (See p. 10.)

The stage of dissection in the present cycle is probably not very different from that of the previous cycle, which was partly interrupted or deranged by the deposition of the loess. Dissection is essentially complete and the divides are narrow, though the limitations of run-off, owing to the ready percolation, prevent minute dissection.

MISSISSIPPI TROUGH.

As indicated in the description of the alluvial deposits (p. 34), the Mississippi is still engaged in corrading the bedrock beneath the alluvium over which it flows at ordinary stages of water. This is partly demonstrated by soundings which have been taken during floods and by which it has been shown that the scour reaches to bedrock; but more satisfactory evidence is derived from the polished and perfectly fresh condition of the bedrock where it is exposed in the building of bridge piers. The cobblestones or bowlders of the overlying gravel are likewise fresh and bear the appearance of being periodically moved and worn. It is to be remembered, however, that the deepest part of the alluvium-filled trough is some distance east of the present channel and may be fully 100 feet deeper than the rock surface beneath the present channel. If, however, the river with its present amount of fall has been able to cut its rock trough to essentially its present depth, it may safely be affirmed that it has not had 
a gradient significantly greater than the present one since it has followed its present course. Had the land stood higher for any considerable time, the rock trough would have been cut deeper than it now is.

\title{
ECONOMIC GEOLOGY.
}

CLAY.

\author{
FIRE CLAY.
}

The fire-clay industry bears a peculiar and interesting relation to the historical and structural geology of the St. Louis area. The clay is found only in the Pennsylvanian strata, a small patch of which has been preserved in St. Louis County because of a slight downward folding. Elsewhere in eastern Missouri these beds lay above baselevel during the long period of erosion which in or before Tertiary time reduced the country to a peneplain. They were therefore planed off, but this small patch lay about 100 feet below the level to which streams could cut.

The output of clay products from St. Louis was, in the year 1908, valued at $\$ 5,000,000$. This is about one-thirtieth of the entire output of the United States. The products here counted comprise those of fire clays, shales, and brick clays. Inasmuch as a very large proportion of the total consisted of fire-clay products, and as these were derived in large part from a single area within the city limits, it may be seen that this area is one of the most important centers of the clay industry.

Mining operations.-The clay is mined like coal from a depth generally less than 100 feet. Both shafts and slopes are used. The mines are owned either by the companies that manufacture the clay products or by independent firms and companies that sell clay to the manufacturers. Following is a list of the chief fire-clay mines in operation when the field was visited, many others having been worked out or closed:

Fire-clay mines in and near St. Louis.

Christy Fire Clay Co............... 4000 Kingshighway boulevard.

Goetz.............................. Sublette and Pernod avenues.

Humes. . . . . . . . . . . . . . . . . . . . . . .

Parker \& Russell....................... Morgan Ford road and Potomac street.

Parker \& Russell..................... Fyler avenue west of Kingshighway boulevard.

Van Cleave........................ Old Manchester and Watson roads.

Krümmel \& Büchner................... Columbia avenue and Woods street.

Guelker.......................... January and Elizabeth avenues.

Laclede No. $1 \ldots \ldots \ldots \ldots \ldots \ldots \ldots$. . . . . . . . . . . .

Laclede No. 2 ................... River Des Peres east of Sulphur avenue.

Evans \& Howard No. 11................Manchester avenue west of Billon street. 
Roberts (Hiram) $\ldots \ldots \ldots \ldots \ldots \ldots \ldots$. Victoria avenue west of Billon street.

Van Cleave....................... Dale avenue near Louisville avenue.

Missouri Fire Clay Co................. Louisville avenue north of Dale avenue.

Hydraulic Press Brick Co. No. 4......... Kingshighway boulevard and McRee avenue.

Stuever (A. C.) . . . . . . . . . . . . . . . Maclind avenue south of Forest Park.

Jamieson-French.................. Hauley road and Bruno avenue.

St. Louis Clay Burning Co............ Castello (near Creve Cœur Lake).

St. Louis Vitrified \& Fire Brick Co...... Castello.

Stratigraphic position.-All the fire clay of the St. Louis quadrangle comes from a single bed known as the Cheltenham bed, for the reason that it is best known and most worked in Cheltenham, a district within the limits of St. Louis, south of Forest Park. This bed lies near the base of the Pennsylvanian. The overlying beds are enumerated in the section on page 25 . The sections on pages $25-26$ show typical examples of the beds which must be passed through in shafting to the fire clay.

Thickness.-The thickness of the Cheltenham bed varies from 1 to 12 feet within a small fraction of a mile. In few places within the area of its occurrence does it pinch out entirely. Most of the mining is done where the thickness ranges from 3 to 8 feet; where it exceeds that amount, as at the northeast corner of the area, only about $s$ feet from the best part of the seam is generally mined. Near the center of the area-in the vicinity of the Laclede mine and those within 1 mile to the south of it-the thickness averages about 7 feet, all of which is good clay and is taken out. The bed is mined at some places where its thickness is as small as $2 \frac{1}{2}$ feet. It is commonly observed that where the bed outcrops it is increased in thickness by the weathering processes. Along River Des Peres through Cheltenham this thickening perhaps amounts to 1 foot, being from 12 to 15 per cent of the original thickness.

Roof.-The variable thickness and changeable character of most of the beds above the clay are of little importance, but the character of the roof is a matter of much concern. The shaly and locally micaceous sandstone listed as No. 6 in the general section (p. 25) is the bed which in all mines supports the overburden and under which all posts must be set. Its thickness ranges from 1 to 7 feet, and it is generally sufficently strong to span all entries and rooms; but when the pillars have been mined out, it breaks off short and falls, allowing the overburden to fall in behind the line of supporting posts. The mining is planned with this in view. The roof is more apt to be too strong than too weak, and in that case it does not break short just behind the row of posts, but sinks down over a large area, squeezing the unmined clay and probably breaking the posts.

Floor.-The floor of the mine is generally the light-colored pyritiferous sand mentioned on page 25 as No. 2. At some places the pyrite is oxidized and the sand is yellow. Here and there, especially 
where the fire-clay bed is very thick, its basal portion is sandy and abounds in pyrite, and is thus poorly distinguished from the underlying sandstone. At other places, as in the Christy and Evans \& Howard No. 11 mines, this basal clay is green and very sandy, locally oxidized to yellow and brown colors. At the latter mine and at the Parker \& Russell mine, west of Kingshighway boulevard, this basal clayey mass contains large red cherts, which elsewhere (in the Laclede, Christy, and Jamieson-French mines) are found only in the underlying limestone.

Local interruptions.-The surface of the floor is locally affected by gentle ridges or rolls rising from a few inches to 1 or 2 feet in a width of a few yards. One such ridge in the floor of the Jamieson-French mine reaches the roof, cutting out the clay entirely. It is known as a "whaleback." Its trend is northwest and southeast.

In several places the roof thickens, its surface being depressed almost or quite to the floor. Such an occurrence in the Hume mine, south of the insane asylum, affects a band some 200 feet wide trending northeast and southwest. Here, as in a similar occurrence, in a group of mines near the southeast corner of Forest Park, the lower surface of the horse is longitudinally grooved or fluted on a large scale.

Water.-On account of the high degree of imperviousness of the overlying beds, most of the mines are practically dry until the pillars have been drawn from some portion, thus allowing settling and cracking of the higher beds. When this stage has been reached, if not earlier, it is necessary to operate pumps continuously. It is common to dig sumps in various parts of the mine and pump from these. Some mines may be pumped from a single sump.

Grades of clay.-The clay bed is rarely of uniform quality throughout its thickness. Its usual variations are due to varying proportions of silica and carbonaceous matter and to the presence or absence of pyrite and other forms of iron. In the western part of the field pyrite, the chief impurity, is found mainly in the upper part of the bed. The lower clay is the highest in grade. It is probable, however, that in this section several feet remaining as floor should be correlated with the basal portion of the bed in Cheltenham. In that district it is common to regard the middle part of the seam as the best, the top being liable to contain carbonaceous matter and the basal portion being siliceous. In the southern part of the field it is customary to consider the clay in two portions, the upper being the higher in grade and the lower being lighter colored and more siliceous.

- Uses.-The choicest of the clay is sold for glasshouse use. At several of the mines the clay is assorted, that which is freest from impurities being sold in the raw condition for glass pots. Good clay which contains a small amount of impurity is washed and then sold 
for the same purpose. For fire brick it is not necessary that the clay be so pure. Much of the fire clay mined in Cheltenham is used without assorting, for ornamental and facing bricks, or is mixed with various other clays to make sewer pipe.

Distribution:-The area from which fire clay is derived has its center in a section of the city known as Cheltenham, lying south of Forest Park. It extends some 4 miles to the southeast in a belt about 2 miles wide; also westward to a line running south from Clayton. An examination of the geologic map (Pl. I) will show that this area is an extension or peninsula of the Pennsylvanian rocks.

The principal geologic condition accountable for the presence of the fire clay within the area named is a faint syncline (see Pl. VI, $B$ ) whose axis, trending north-northwest, passes not far from the southeast corner of Forest Park. North and east of this point there are no mines. Still smaller folds are probably accountable for certain small variations from the general structure here described, but such folds are too small to be reduced to system with any data now obtainable. The lowest level from which the clay is mined is 404 feet above the sea, at a point within the bend of River Des Peres, near the southeast corner of Forest Park. From this point the elevation of the bed increases both to the west and to the south. The highest known level of the clay is 494 feet, in the Van Cleave mine, about a mile northwest of the insane asylum, near the intersection of Old Manchester and Watson roads. West of that point the strata are affected by a gentle anticline over which River Des Peres flows toward the southwest, the combined effects of the folding and erosion being that the clay is absent from this area. Similar conditions on the east and south of the productive area have caused the complete erosion of the clay-bearing rocks.

The productive area south of Clayton lies beyond the low anticline above mentioned from which the Pennsylvanian rocks have been stripped. The northerly pitch of these exceedingly gentle folds has caused them to disappear just south of Forest Park, thus leaving the Cheltenham district connected by continuous Pennsylvanian strata and probably by a continuous bed of fire clay with the district south of Clayton which contains the Jamieson-French mine.

At Castello, about 9 miles northwest of Cheltenham and 3 miles east of Creve Cœur Lake, the St. Louis Vitrified and Fire Brick Company operates a mine and factory. That the horizon of the clay here mined is the same as that of the Cheltenham fire clay is practically certain from its relations. The base of the fire-clay bed at this point is nearly 90 feet below the upland level; the dip is very slight and the base of the Pennsylvanian comes to the surface half a mile west of this mine at an altitude about 50 feet higher than that of the clay at this point. It is therefore highly probable that the base of 
the Pennsylvanian is not much if any below the clay at this place. As elsewhere, the floor here consists of sandstone with ferruginous nodules. Moreover, at the St. Louis Clay Burning Company's -plant, half a mile to the southeast, limestone is reported beneath this sandstone, as in the Cheltenham district.

The thickness of the bed at Castello is 12 to 15 feet, 12 feet of good clay being mined. Above the clay lies 55 feet of soft shale, mostly of a red color. Essentially the same section was noted in drilling at the St. Louis Clay Burning Company's plant, half a mile to the southeast. There is also a fire-clay mine at Malcolm station, southeast of Creve Cour Lake, where the section is the same, including the 18-inch coal bed.

Fire clay has long been known north of Baden, a northern suburb of St. Louis. At the shale quarry of the St. Louis Portland Cement Company the massive shale which is mined is underlain by 2 to 3 feet of black shale and this by $1 \frac{1}{2}$ feet of coal, beneath which is the fire clay, said to be 25 feet thick. It is highly probable that the fire clay at this place occupies a sink hole which was formed during the mid-Carboniferous land epoch.

In view of the wide separation of the points at which the Cheltenham fire-clay bed is mined, it is quite probable that it may be found at many places where no prospecting has yet been done.

SHALE.

A characteristic feature of the Pennsylvanian strata near St. Louis is their very large proportion of plastic shale. This is largely used in the manufacture of vitrified paving brick both in St. Louis and to the northwest near Creve Cœur Lake. This shale is the same as that which appears in the sections above the fire clay (see pp. 25-26) but west and north of the city it occurs in thicker and more continuous beds of uniform quality. At Castello and Malcolm stations almost the entire 40 to 55 feet intervening between the loess above and the coal bed overlying the fire clay consists of workable shale, generally of a red or brown color but with some blue shale at its base.

Similar clay 4 miles northwest of Glencoe, a station on the Missouri Pacific Railway some 25 miles west of St. Louis, is largely used in St. Louis in the manufacture of terra cotta and sewer pipe. Shale from this vicinity has also at times been used extensively for brick.

\section{BRICK CLAY.}

Many yards in ana around St. Louis are making common red brick from the loess, which is commonly called "yellow clay." It is rarely less than 10 or 15 feet thick and near the bluffs may have three or four times that thickness. It differs in texture at different depths, the upper portion being "stronger," more claylike, and less mealy than the main body. (See p: 33.) Partly to obtain a thor- 
ough mixture of these different grades and sometimes to allow some weeks or months of "sweating," thus reducing all lumps, large quantities of the loess are commonly brought in from the pits and kept under shed for some time before using. A good grade of red brick is made, and the supply of good loess here and elsewhere is practically limitless.

QUARRY ROCK.

Numerous quarries have been opened in this area, at least 25 being worked at the present time within the city limits of St. Louis. The product of any one quarry is generally varied in character and used for diverse purposes.

\section{SPERGEN LIMESTONE.}

The Spergen limestone is quarried at Meramec Highlands (see p. 22) and on Gravois Creek, at the west end of the outcropping strip shown on the geologic map. A 10-foot massive bed at the top yields large blocks well suited for dimension stone. The use of this stone has as yet been small, and its merits other than easy working and good appearance are not known.

\section{ST. LOUIS LIMESTONE.}

The quarries in the city of St. Louis are all in the St. Louis limestone. Quarries have been opened in the same formation in the west bluff of the Mississippi south of St. Louis and in the Illinois bluff south of Stolle; also in the bluff of the Missouri north of Creve Cœur Lake. Rock from this formation is also taken out of several quarries on the Meramec, where the chief product comes from the Spergen limestone below.

The St. Louis limestone is at present used principally for road material and foundation stone. A considerable amount is also used for curbing and sewer plates and in the manufacture of whiting. A number of beautiful and durable superstructures have been built of this stone, but it is not in general favor for that purpose. The beds used in this way range in thickness from less than 6 inches to perhaps 1 foot. Many of them are of the very dense and hard variety (see p. 24) and require careful dressing with the hammer. Certain thick beds are said to be well suited to dimension stone, but they are not so used, probably in part because of their dusky color. Chert is so distributed throughout many quarries that their operation for structural materials alone would not be feasible. The use of the remaining material as road metal insures the necessary economy, and the crusher is therefore an adjunct of almost every quarry. The material used for whiting is taken from any bed of pure limestone. The dense beds of lithographic texture are especially valuable for this purpose.

Quarries in the bluffs commonly work a face from 40 to 80 feet high. They can usually be drained without pumping. Quarries not in the bluffs are generally abrupt vertical-sided pits, some of them 
as deep as 80 feet. The stone is commonly elevated by a hoist, though most quarries still have also an inclined roadway. The water must generally be pumped from such pits, though from a few pits the water has temporarily passed out at the bottom into natural passages leading to the river. Such quarries are not far from the bluffs, and their sites were formerly occupied by sink holes. It is said that such sites have sometimes been chosen with a view to the drainage.

\section{PENNSYLVANIAN SERIES.}

Sandstone from the Pennsylvanian has been quarried at various places, but its weakness restricts its use to foundations of small buildings and it can scarcely be said to be an article of trade. Northwest of Clayton a thick bed (probably No. 10 in the section, p. 26) was used in this way before the opening of the quarries in the St. Louis limestone at Vigus. Other openings in similar ledges of uncertain position are all small.

\section{LIME.}

Little limestone is used for making lime within the St. Louis quadrangle. West and south of the quadrangle the Kimmswick limestone is largely used for this purpose. In 1890 a study was made ${ }^{a}$ of various limestones outcropping in St. Louis County and city, with a view to their larger use in the making of lime. The analyses made in the course of this study show that a considerable portion of the St. Louis limestone contains more than 89 per cent of carbonate of lime, but the industry remains, as it was before, largely confined to the Kimmswick outcrops.

\section{CEMENT MATERIALS.}

The cement industry in and near this area is confined to the large plant of the St. Louis Portland Cement Company at Prospect Hill, just north of Baden, a northern suburb of St. Louis. This plant is using the shale of the Pennsylvanian series in connection with the St. Louis limestone, approximately in the proportion of 36 parts of the former to 130 parts of the latter.

The shale is taken from a large quarry in the Mississippi bluff immediately adjacent to the factory. This quarry shows the following section:

\section{Section at shale quarry of St. Louis Portland Cement Company.}

6. Loess, 5 feet of which at the base grades into a ferruginous residual clay.

5. Yellowish-gray shale, poorly consolidated ...................... 18

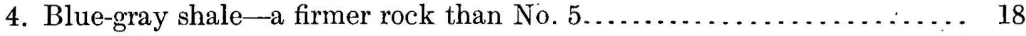

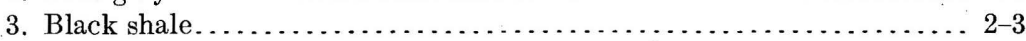

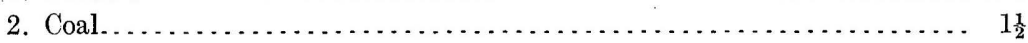

1. Fire clay.

$a$ Ladd, G. E., The clay, stone, lime, and sand ind ustries of St. Louis city and county: Geol. Survey Missouri, Bull. No. 3, 1890, pp. 73-84. 
Nos. 6, 5, and 4 are used, being mixed in the proportions yielded by the quarry. The free silica of the loess, being in very fine grains, is not objectionable in the quantities afforded. In No. 5 the silica may be as high as 60 per cent, but it is in very large part combined and very little grit is noticed in the shale. This is even more true of No. 4 , in which the silica does not generally exceed 55 per cent. The highest proportion of iron is found in No. 4 (5 to 5.5 per cent) despite the higher color in No. 5 due to oxidation. No. 4 contains also the largest proportion of alumina (22 to 25 per cent). The lime, magnesia, and alkalies are all low.

The limestone is obtained from quarries 8 miles north of the factory, in the south bluff of the Missouri opposite Bellefontaine. It is the St. Louis limestone and contains a very high percentage of carbonate of lime.

The capacity of the plant is at least 75,000 barrels of cement a month.

\section{SAND AND GRAVEL.}

GLASS SAND.

Though glass sand must be obtained beyond the limits of the quadrangle, the manufacture of glass is carried on within the area at two places. Valley Park, Mo., has large plate glass works and Belleville, Ill., has extensive bottle works. Sand is dug from the St. Peter sandstone at Crystal City, where there are also factories, and at Pacific. The latter place supplies sand for the St. Louis Plate Glass Company's large factory at Valley Park.

The merit of the St. Peter as a glass sand consists in part in its friability, by reason of which it is easily excavated and prepared for the factory. Its chief merit, however, is its high degree of purity. Even as obtained in its natural condition the constituents other than pure silica in much of it amount to less than 1 per cent. The most deleterious of these impurities is iron oxide, which appears sparingly in the cement. Its tendency is to discolor the glass. The only other impurity of importance is clay, or the so-called alumina.

The sand is dug from the bank rather than quarried. It is then ground in order to separate all the grains, after which it is washed, the clay being carried away by a stream of water. The sand is then pumped to an appropriate place and dried, after which it is ready for the factory.

At Pacific, the stratum of sandstone suitable for glass making is said to have a total thickness of about 110 feet, being found in hillsides to a height of 60 or 70 feet and underlying the valley to a depth of 40 feet or more. Sand is now taken from the hillsides only. The topographic relations are similar for a number of miles. Probably the purity of the sand will be found to vary from place to place, but the amount available for the future is very large. 


\section{BUILDING SAND.}

Sand for structural use in St. Louis is practically all pumped from the bed of the Mississippi by a single company, the New Union Sand Company. The sand thus obtained is composed chiefly of fairly sharp quartz grains with an admixture of igneous rock fragments ranging in size up to that of a pea. Occasionally gravel is encountered in "reefs" or long, narrow strips either longitudinal or transverse with reference to the channel. Clay is found here and there in sheets, few of which reach 1 foot in thickness. All the deposits are changeable in composition from place to place, as is to be expected from their origin. At times "live sand" is found-that is, the sand is replaced by the current approximately as fast as it is pumped.

Sand is pumped from a maximum depth of fully 40 feet through 14 -inch pipes at a maximum rate exceeding 300 cubic yards an hour. The barges used have a capacity of 400 cubic yards. It is customary to fill 12 or 14 of these barges daily.

\section{MOLDER'S SAND.}

Molder's sand is sold in considerable quantities by several firms in St. Louis and the outlying towns. The sand thus used is of diverse geologic origin, but most of it is loess. In the southern part of St. Louis certain alluvial sands occurring in a terrace of River Des Peres have been prospected with a view to use as molder's sand. Though little used up to this time, they will probably be satisfactory.

All pits dug for molder's sand in the loess are in the bluffs of the Mississippi, most of them on the east side, from Peters station, on the north, to French Village. Some of this loess comes from the base of the bluif and underlies minutely laminated sands and silts. There is therefore strong though not conclusive reason for believing that such loess was deposited in water. $\Lambda$ t other places, as on Schoolhouse Branch, 4 miles south of Peters station, molder's sand is taken from the loess near the crest of the ridge which caps the east bluff. (See p. 33.) At this place it likewise contains large numbers of pulmoniferous shells, so that the strongest arguments for an eolian origin apply to these deposits. From experience thus far, therefore, those qualities of loess which fit it for molding can not be said to be associated with any one origin.

The molder's sand taken from the loess is of the finer grades, some of it, notably that from the crest of the bluff, being best fitted for small castings, brass castings, stove-plate, etc. Much of this bluff deposit is, however, a "general-purpose sand," being used with excellent success for castings as heavy as radiators.

Large quantities of sand sold in St. Louis come from the vicinity of East Alton, Ill. The deposit at this place is described as forming a ridge on the edge" of a terrace and is inferred to be made up of eolian 
loess in a position like that of the loess at Bonfils station, opposite St. Charles (p. 10). The sand from East Alton is of medium grain. It has been used as a general-purpose molding sand for many years.

The sand from the River Des Peres terrace is plainly an alluvial deposit, occurring in a local bed perhaps 5 feet thick. Its grains are angular, though not very diverse in size. It contains some grains of feldspathic and ferromagnesian minerals. There is also a ferruginous pasty coating to the grains which suggests the decomposition of basic igneous grains. This sand, like some others examined, seems to owe its materials to the glacial drift. It has been long enough in its present position to allow partial decomposition of the silicates. A little less perfect assortment and a consequently greater variety of size of grain and a little less rounding by wear would have left a more ideal molder's sand.

In general, the property desired in molder's sand is the ability to pack into a firm mass without loss of porosity or liability to large shrinkage. Without porosity the steam caused by the molten metal can not escape and the mold will rupture. 'The disadvantage of shrinkage is evident. The packing qualities of a molder's sand must, therefore, not be due to clay. In so far as packing can be brought about by diversity of size and angularity of grain it will not involve shrinkage or want of porosity. Any actual adhesion within the best sands examined is due mainly to iron oxide.

\section{CEMENT GRAVEL.}

The so-called cement gravel used for roadways and walks is merely gravel which contains sufficient "binder" to cause packing. If the constituent stones of the gravel are of very diverse size, the porosity is small and the amount of binder required is correspondingly small. This commonly consists of clay or of iron oxide.

The Lafayette gravel is fairly well fitted to use where packing is necessary. Its pebbles are much rounded, a feature which interferes with packing, but there is sufficient diversity in their size and a sufficient abundance of the plastic sandy loam (see p. 30) to cause packing. The plasticity and binding properties of this loam are due to its clay and its abundant oxide of iron. The Lafayette gravel is used to some extent for streets where heavy hauling is not permitted.

\section{OIL AND GAS. $a$}

At many places in this area drilling has revealed small quantities of petroleum and natural gas. Most of such occurrences are in the Plattin ("Trenton") limestone, though still smaller quantities are

$a$ The account here given is based on the field work of 1906 . Since that time new wells have been drilled on Vandeventer avenue and the gas is again used. Gas has also been discovered and is being used at a number of places from Carondelet on the south to a point several miles north of Normandy Heights; also at Cahokia, Ill., and on the bank of the Mississippi north of East St. Louis. It is probable that the study of sections of these new wells will disclose small folds not previously known. 
encountered at'higher levels, having probably escaped upward from the Plattin limestone.

\section{AREA IN ST..LOUIS.}

The best known of these wells are near the center of St. Louis, on the north end of the pitching anticline described on page 36 , and shown in cross section in Plate VI, $B$. At the Welle-Boettler bakery, on the corner of Vandeventer avenue and Forest Park boulevard, three wells entered the Plattin limestone. One of these found little indication of either gas or oil, but tapped a very heavy brine in the Plattin. Another found a similar brine and likewise a quantity of gas, which was used under bake ovens for about six months in 1904 . It was equivalent at the start to 7 or 8 bushels of coke daily. The closed pressure is said to have reached 240 pounds per square inch, but the circumstances under which this observation was taken are not known. The pressure gradually weakened, until at the end of one year but little gas continued to escape. This well when pumped yielded about a barrel a day of heavy, black, ill-smelling oil. It is known that both gas and oil come from levels below 565 feet, and probably below 600 feet.

The strata passed are known in part from the following log of a well drilled in November, 1904. This well is one of three, no two of which are more than 200 feet apart.

Log of well on northwest corner of Vandeventer avenue and Forest Park boulevard, St. Louis, Mo.a

\begin{tabular}{|c|c|c|}
\hline$\cdot$ & $\begin{array}{l}\text { Thick- } \\
\text { ness. }\end{array}$ & Depth. \\
\hline Filled ground. & Feet. & Feet. \\
\hline Soft gray clay. & 20 & 40 \\
\hline Sand and gravel. & 20 & 60 \\
\hline Hard gray limestone, shaly; a little water... & 20 & 80 \\
\hline 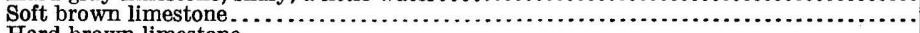 & 20 & 100 \\
\hline 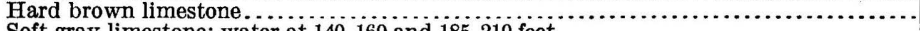 & 20 & 120 \\
\hline Soft gray limestone; water at $140-160$ and $185-210$ feet....... & 120 & 240 \\
\hline & 20 & \\
\hline 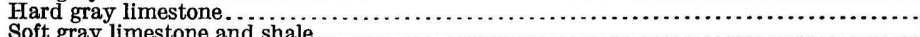 & $\mathbf{5}$ & 265 \\
\hline 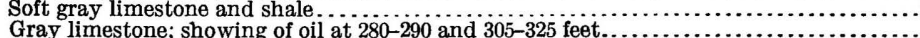 & $\begin{array}{r}15 \\
180\end{array}$ & $\begin{array}{l}280 \\
460\end{array}$ \\
\hline 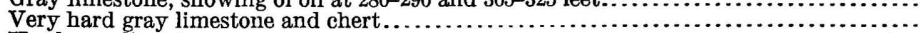 & 10 & 470 \\
\hline 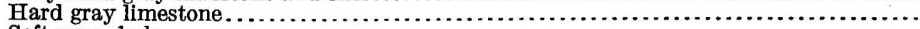 & 15 & 485 \\
\hline Soft gray shale & 5 . & 490 \\
\hline Hard gray limestone... & 20 & 510 \\
\hline 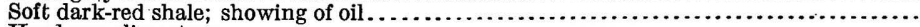 & 20 & 530 \\
\hline Hard gray limestone $\ldots \ldots \ldots, \ldots \ldots \ldots \ldots \ldots$ & 35 & 565 \\
\hline 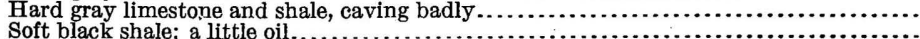 & $\begin{array}{l}35 \\
20\end{array}$ & $\begin{array}{l}600 \\
620\end{array}$ \\
\hline Soft brown limestone, Trenton; a little oil.... & 30 & 650 \\
\hline
\end{tabular}

The well yields a small amount of gas.

In drilling one of the other two wells (not the productive gas well) samples were carefully kept and labeled to indicate the depth. The description of these agrees in the main with the $\log ^{3}$ given above.

a Obtained by E. O. Ulrich from the driller, E. D. Meloy, and published in Bull. U. S. Geol. Survey No. 264,1905 , p. 89. 
Samples from well at Welle-Boettler bakery, St. Louis, Mo.

\begin{tabular}{|c|c|}
\hline $\begin{array}{l}\text { Depth } \\
\text { in feet. }\end{array}$ & $\begin{array}{l}\text { Depth } \\
\text { in feet. }\end{array}$ \\
\hline Fine gravel.. & Gray limestone..... \\
\hline rown limestone.. & Brown limestone.... \\
\hline ray limestone. & Gray limestone.. \\
\hline ame.......... & Gray shale. . \\
\hline ame......... & Dark, nearly black, calcareous \\
\hline ame. . & shale..................... 610 \\
\hline Same........... & Limestone............. 624,640 \\
\hline ame............ & Same. (May be mixed with \\
\hline imestone and chert. . & hale) $\ldots \ldots \ldots \ldots \ldots \ldots \ldots 66$ \\
\hline ….... & Blue noncalcareous shale..... 685 \\
\hline ame. & Dark - brown \\
\hline Same................. & shale $\ldots \ldots \ldots \ldots \ldots \ldots \ldots \ldots+735$ \\
\hline $\begin{array}{l}\text { Limestone with brown sh } \\
\text { (Fern Glen) } \ldots \ldots \ldots \ldots \ldots\end{array}$ & $\begin{array}{l}\text { Gray limestone ..... 805, 850,900 } \\
\text { Brownish-gray limestone..... } 934\end{array}$ \\
\hline $\begin{array}{l}\text { Brown shale or lime } \\
\text { Glen) } \ldots \ldots \ldots \ldots\end{array}$ & \\
\hline
\end{tabular}

From the above log and samples it is known that the base of the red shale of the Fern Glen is at 530 feet. This is underlain first by 35 feet of hard gray limestone and then by 35 feet of limestone and shale said to contain small quantities of oil. Still lower is 20 feet of black shale which undoubtedly contained some oil. The correlation of these beds beneath the Fern Glen is uncertain, but there is little reason to doubt that the stratum beneath these, a soft brown limestone between 620 and 662 feet, is Kimmswick limestone. ${ }^{a}$

Less than half a mile south by east from the above-described wells, at Tamm's glue factory, is a well which for a short time yielded a considerable amount of gas. Samples taken during the drilling indicate that this gas came from essentially the same horizon as that at the bakery. The base of the red shale of the Fern Glen is here at a depth of 505 feet. As the surface of the ground is 10 or 15 feet lower than at the Welle-Boettler wells, this indicates a northerly dip of the strata of not more than 10 or 15 feet within that distance. Allowance must be made for liability to error in reporting depths, for the dip as determined by other horizons is considerably greater. The section of Tamm's well below the Fern Glen is as follows:

Partial section of well at Tamm's glue factory, St. Louis, Mo.

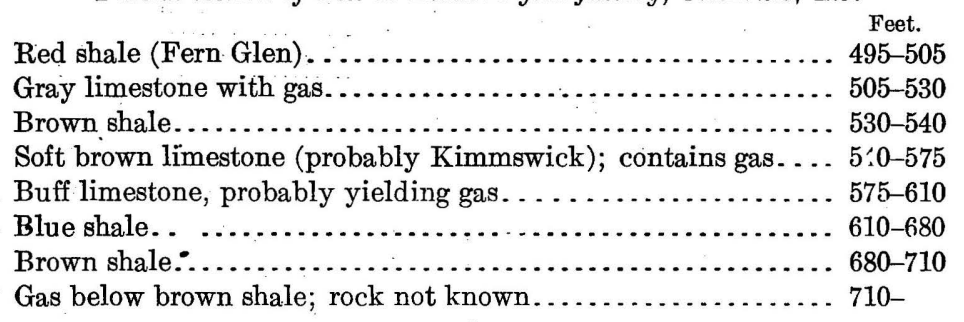

$a$ E. O. Ulrich (BuIl. U. S. Geol. Survey No. 264, 1905, p. 90) provisionally classes the 70 feet of limestone beneath the Fern Glen as Kinderhook and the 20 feet of black shale as the Ohio shale (Devonian). 
Drops of oil similar to that found in the Welle-Boettler well were frequently observed. Like several of the wells above mentioned, this well was shot with dynamite.

At the quarry of the Fruin-Bambrick Construction Company, onethird of a mile southeast of Tamm's well, similar pockets of gas were encountered at slightly higher levels and in similar rocks. The section is almost identical with that of the Tamm well.

At various other places in St. Louis "showings" of oil have been observed in deep wells. A well drilled in 1905 at the Union Brewery, Gravois and Michigan avenues, St. Louis, encountered a very small amount of oil, but its depth is variously stated. It will be observed that this location is south by east of those mentioned above, not far from the axis of the anticline. A similar showing is said to have been found in a well drilled fifteen or twenty years ago at the Grone brewery, Twentieth street and Clarke avenue.

\section{MISSISSIPPI FLOOD PLAIN.}

On the flood plain of the Mississippi, 2 miles southwest of Peters station, in the northeast corner of the area, a well was drilled for oil on the Kellar farm to a depth of 1,504 feet. Between the depths of 1,260 and 1,504 feet this well traversed Ordovician ("Trenton") limestone which yielded a small amount of good-looking oil, having an olive-green color by reflected light and a brownish-red color by transmitted light. The odor of the oil is agreeable. Its gravity is variously stated between $35^{\circ}$ and $41^{\circ}$ Baumé.

When the Kellar well had been abandoned for many months, the oil continued to escape at a rate of perhaps 1 or 2 gallons a day. Gas likewise continued to rise, causing a continual bubbling or gurgling. Perhaps 75 barrels of oil have been pumped from the well. It was estimated by the owner that the well might have yielded regularly 10 barrels a day. Strong salt water issues from outside the casing at the rate of several barrels an hour. This is believed to come from the sandstone overlying the St. Louis limestone at a depth of 420 feet.

The formations traversed by this well are shown in the section in Plate VI, $A$. The character of each is shown in the following log:

Log of Kellar oil well, near Peters station, Ill.

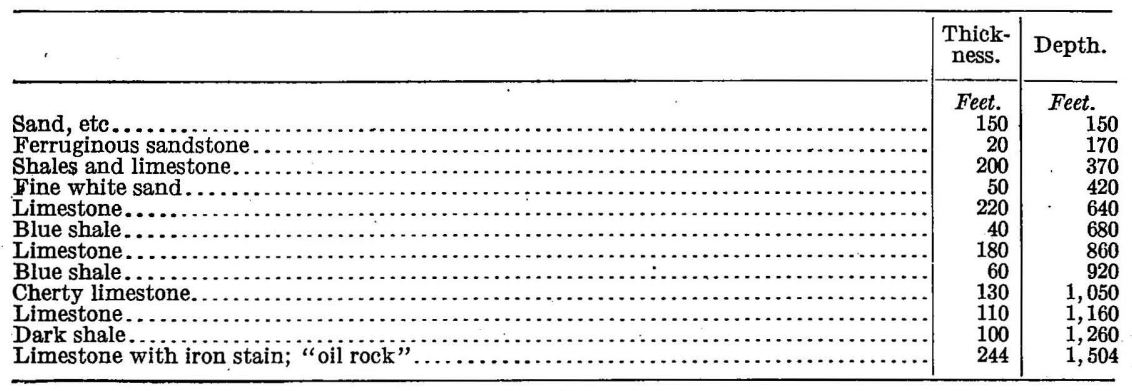


Drilling is now in progress a short distance north of Peters station, about 4 miles from the Kellar well.

\section{REGION WEST OF ST. LOUIS.}

Attempts have been made to find oil at several places west of the area mapped. A well sunk by the Glencoe Lime and Cement Company, 2 miles northwest of Glencoe, entered the Plattin limestone at the surface, striking the St. Peter sandstone at a depth of 110 feet and passing a succession of sandstones and limestones to a total depth of 1,500 feet. Only an occasional "odor of gas and oil" was discovered. Similar results were obtained at Rankin station, 2 miles west of Valley Park, where the corresponding formations were found 300 or 400 feet deeper. Thus far no valid reasons exist for expecting valuable deposits in this area below the Plattin limestone.

\section{PROSPECTS.}

Many reports of oil are based on nothing more than a limonitic scum on stagnant water. Others have for their basis an insipid or disagreeable taste of well waters which is in no way related to oil.

So far as oil and gas have yet been found in this region, their occurrence is exactly where it should be expected from a study of the structure, namely, on the crest of a gentle anticline. It is not improbable that there are similar anticlines not now known. Other similar pockets of gas and oil may therefore be found in the future. So long as they remain undiscovered there is no positive evidence that larger ones may exist than those already found. Any search for them should be preceded by a careful exploration of local folds. This is emphasized by the remarkable agreement of the distribution so far as known with the anticlinal theory.

Difficulties in applying this theory to the St. Louis region arise (1) from the loess cover and the fewness of the outcrops; (2) from three unconformities of erosion and, to an unknown extent, of angle. The first of these unconformities is between the Kimmswick limestone, which contains the supposed deposits, and the overlying upper Ordovician shale believed to be of Maquoketa age. The second is between the Ordovician system and the Carboniferous. Discrepancy of angle corresponding to these unconformities has not been shown in this area, and it is probably not great if it exists at all. It is to be remembered, however, that the localization of gas and oil is determined by relatively small folds. The third unconformity is between the Mississippian and the Pennsylvanian series. Although a distinct unconformity of angle at this horizon is not shown within the area considered, it is known to exist at places somewhat nearer the Ozarks, and may yet be found in this area. To judge from the wells whose logs were obtained there is a strong supposition that in the small 
anticline in St. Louis which has given showings of gas and oil the Kimmswick limestone is essentially parallel to the beds at the surface (St. Louis limestone).

COAL.

ILLINOIS.

The area studied embraces a portion of the western margin of the Eastern Interior coal region. An adequate treatment of the coal beds in the St. Louis quadrangle would therefore require the study of a much broader area.

There is but one bed of commercial importance here, known as the Belleville bed or No. 6 of the Illinois reports, the most extensively mined bed in the State. Its position and that of the smaller beds or blossoms are shown in the sections (pp. 25-28). The thickness of the Belleville bed ranges from $5 \frac{1}{2}$ to $7 \frac{1}{2}$ feet, with an average of more than 6 feet. $^{a}$ It contains a few knife-edge partings of sulphur and at places one or two shale or bone partings about half an inch thick.

The depth of this bed beneath the upland is from 150 to 160 feet at Belleville and about the same at Collinsville. West of the former place and south of the latter the coal approaches the surface, outcropping in the Mississippi bluff as far south as Centerville. Farther south its line of outcrop extends southeastward across the upland.

A number of shafts are clustered around Belleville and Collinsville, but most of these are east of the St. Louis quadrangle. Along the bluff from Caseyville to Centerville coal has been taken from a number of slopes, but these are practically abandoned.

The roof is commonly of shale, having a thickness varying from a few inches to a few feet, and overlain by a strong limestone. The floor is a clay or soft clay shale; it is locally called fire clay, but its utility as such has not been determined.

The properties of this coal may be judged from the analysis of a sample from a mine of the Western Anthracite Coal and Coke Company, known as the St. Louis and O'Fallon No. 1, or Nigger Hollow, mine. It is located $5 \frac{1}{2}$ miles west of south from O'Fallon, Ill. The analysis of this coal is as follows:

Analysis of coal from St. Louis and O' Fallon mine No.,1.b

Proximate:

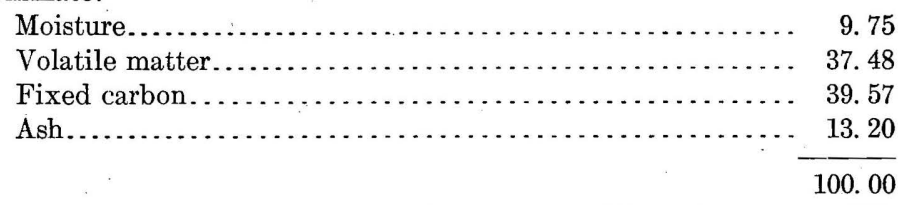

$a$ This coal was sampled by M. R. Campbell and tested at the coal-testing plant in St. Louis. Most of the data concerning it are found in Bull. U. S. Geol. Survey No. 261 and Prof. Paper No. 48.

b Prof. Paper U. S. Geol. Survey No. 48, 1906, p. 206.

74449ㅇ-Bull. $438-11-5$ 
Ultimate:

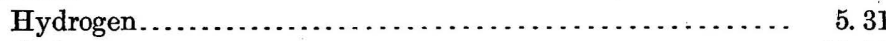

Carbon......................................... 59.72

Nitrogen...................................... 1.03

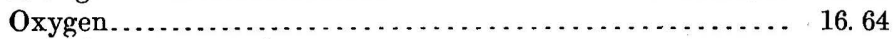

Sulphur....................................... 4.10

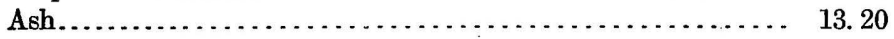

100.00

Calorific value:

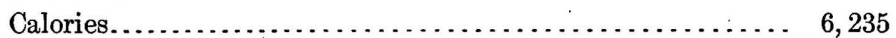

British thermal units............................ 11, 223

This is the analysis of a car sample representing 15 tons of coal. As the loss of moisture on air drying was 3.7 per cent, the analysis of the air-dried sample showed all the other figures somewhat larger than here given.

From the above data the fuel ratio is seen to be 1.06. The ultimate analysis shows the carbon-hydrogen ratio to be 12.2. This coal therefore falls in Group I, the lowest group of bituminous coals according to the classification proposed by the authors of the report cited.

The output of the mines in this vicinity is in general use as a steam coal. In the lump condition it does not coke, but on experiment a partial success in coking has been attained with the slack after being washed to reduce the excessive amount of ash. The high percentage of sulphur originally present in gypsum would prevent the use of this coke in blast furnaces or cupolas, but would not interfere with its use for lead or zinc works.

The output of coal in this area is not definitely ascertained, but the two counties represented are among the foremost coal-producing counties of Illinois, St. Clair County in 1908 ranking fourth, with a production of $3,696,017$ tons, and Madison County fifth, with $3,367,820$ tons.

\section{MISSOURI.}

On the Missouri side of the river the same gentle downward folding which has resulted in the preservation of the Cheltenham fire clay from erosion has preserved one or two thin beds of coal. One of these, which is very local in extent and has a maximum thickness, in this part of the field, of perhaps $1 \frac{1}{2}$ feet, lies immediately above the fire clay. Another, equally local and having a maximum thickness of 4 feet, lies about 50 feet higher. Both of these were mined in the early history of St. Louis, and although their content was such as would now be considered insignificant, their influence on the early development of the city's industries was great. They are not mined at the present time, except incidentally in the mining of the clay. 
WATER RESOURCES. $a$

STREAMS AND LAKES.

Owing to the large city population of this area, a large proportion of the water used for domestic and manufacturing purposes is derived from city water systems which obtain their supply from Mississippi River. As it comes from the river this water is muddy and hard. It is subjected to straining, settling, aeration, chemical treatment with iron sulphate and quicklime, and sometimes to filtering. By these methods it is rendered clear and relatively soft and agreeable to the taste. The waters of the smaller streams and oxbow lakes of the flood plain have been used to a small extent by manufacturing establishments, but those of the lakes at least are muddy and very hard and are not in favor.

\section{SHALLOW WELLS.}

The use of water from shallow wells for domestic purposes is common. It is estimated that even in the densely populated parts of St. Louis there were in 1906 between 2,000 and 3,000 surface wells in regular use for domestic purposes. A steady diminution in their use results partly from the excellence of the city water supply and partly from the vigilance of the health department, which is educating the users as rapidly as possible. The number of such wells in use a few years ago was approximately 8,000.

WELLS ON THE MISSISSIPPI FLOOD PLAIN.

Wells on the flood plain are dug, or more commonly driven, to one of the many gravelly beds intercalated in the sand which constitutes the great body of the alluvium below the surface clays. The surface of the ground water on the flood plain varies from a few inches to a few feet beneath the surface, but in the clays near the surface the movement is so slow that wells in it would have small capacity. The same is true in a less degree of the sands. The gravels have no larger proportion of pore space than the sands, but as the openings are larger the water passes through them and into the well at a more rapid rate. The depth of these flood-plain wells varies from 10 to several hundred feet. The deeper wells traverse many water-bearing gravels, thus obtaining a greater capacity. Near the edge of the flood plain, where its surface rises toward the bluff, it is necessary to go much deeper to find the first water-bearing bed than it is near the river.

$\dot{a}$ Some of the data concerning water resources have been obtained from the field notes and manuscript of Isaiah Bowman, the results of whose work on the water resources ol the East St. Louis district have since been published by the Illinois Geological Survey as Bulletin 5, Water resources of the East St. Louis district, 1907. Many of the points mentioned here are discussed by him in greater detail so far as they relate to the east side of the river. 
WELLS ON THE UPLAND.

Many wells on the upland go to the more gravelly basal portion of the loess, obtaining there a moderate supply of good water, though in many of them it has a clayey taste. The depth of such wells east of the Mississippi ranges from 20 to 80 feet, averaging probably about 30 feet. West of the Mississippi the depths are less. On the Illinois side many walls for domestic use enter the glacial drift, the water thus obtained being less liable to contamination than that which comes from the highly porous loess.

In those portions of the upland where sink holes are numerous wells are at a disadvantage in various ways. The water which descends in the sink hole follows an enlarged jointing crack or a true cave, different streams thus formed being at very different levels within short distances. The clogging of some of these passages makes the difference of level in near-by cavities still greater. As the intervening limestone is dense, the getting of well water depends on the striking of such an opening. The resulting uncertainty of depth deters many from attempts to find water in this way.

A second disadvantage in reliance on wells in a sink-hole region is the turbidity of the water after rains. This condition is especially prevalent in this loess-covered region, where rains wash the loess into subterranean passages in the same manner as it is washed into streams, leaving the waters in the former quite as turbid as in the latter.

A third and more serious consideration is the ready washing in of contaminating materials and the traveling of such constituents for long distances without that purification which attends slow percolation. This danger appeals less to most people than the disadvantages above mentioned, but here and there it is more or less consciously realized.

All these considerations adverse to shallow wells in sink-hole districts apply to the city of St. Louis, where sink-holes were formerly numerous. The consideration last mentioned has added force on account of the many sources of contamination in a great city.

\section{CISTERNS.}

As a result of the above-stated considerations, the custom of using cistern water for all domestic purposes is very general in the sink-hole regions and to some extent in the other parts of this area. A decided difference in this respect is, however, noticed between the area underlain by limestone and that underlain by the Pennsylvanian shales, the latter having relatively few cisterns. 
SPRINGS.

Springs occur in this area in considerable numbers, issuing at various horizons. Small springs and seepages are not uncommon at the contact of the loess and the Pennsylvanian shales. Many issue from passages or incipient caves in the St. Louis limestone. The Osage group contains similar though smaller and less abundant passages.

At Falling Spring, 2 miles south of Stolle, Ill., a large underground passage in the St. Louis limestone emerges halfway up the side of a 150-foot cliff. The discharge, which forms a tributary to Prairie du Pont Creek, is equivalent to the flow from a 12 or 15 inch pipe and is used for steam in locomotives. The source of this water is the very much pitted upland extending for several miles to the east. The numerous sink holes in this area conduct all the water to underground passages and run-off is entirely lacking.

DEEP WELLS.

\section{CARBONIFEROUS SYSTEM.}

Many of the deep wells derive their water from the St. Louis limestone. The water is generally of agreeable taste, but is always hard and sometimes salty. The various sands of the Carboniferous likewise yield water. The principal one of these on the Illinois side is the thick stratum (50 to 75 feet) at the base of the Pennsylvanian, provisionally classed as Chester. At Belleville the city water supply is derived from this sandstone, which is there from 500 to 600 feet below the surface. In the northeastern part of the area the water from this stratum, though abundant, is salty. The constant flow of salt water from the Kellar oil well, 2 miles south of Peters station, is thought to be largely from this stratum. Salt water may also be found in the higher sandstones of the Pennsylvanian, as at Mascoutah. ${ }^{a}$

The limestones of the Osage group (Keokuk and Burlington), where near enough to the surface to be subject to weathering, are in many places cavernous and good water bearers, but where deeply buried they are relatively compact and yield less water. The water derived from them is frequently salty, as was noted in drilling the Belcher well, the wells on the Keyes dairy farm near Valley Park, and the wells at the ice factory at Mentor. In the Kellar oil well the lime'stone is reported as a "salt sand."

The water from the Kinderhook formation, where that is covered by other strata, as east of the Mississippi, is similarly brackish and unfit for domestic use. This formation is frequently encountered in drilling deep wells in St. Louis and its waters are cased off. The water is often spoken of as containing "soluble sulphur," doubtless in allusion to the 
various sulphates resulting from the oxidation and decomposition of iron pyrite. Some such waters have a peculiarly flat, insipid, or disgusting taste.

ORDOVICIAN SYSTEM.

The limestones and shales of the upper Ordovician yield little water. in this area where deeply buried. The strong salt water in some of the wells drilled for gas comes from this horizon. South of the area near Kimmswick and Sulphur Springs, Mo., great springs issue at the horizons of the Kimmswick and Plattin limestones. These springs are strongly marked by sulphur and salt and at least one contains magnesia. It is not certain, however, that either the abundance of this water or its character is due to the nature of the rocks from which it issues. They may perhaps be best explained by referring it to the underlying St. Peter sandstone.

The St. Peter sandstone throughout the area studied bears water abundantly. It is almost universally characterized by salt or sulphur, or both. It is the source of water in many artesian wells of St. Louis, among them the Belcher well, which is widely known for its mineral character. The capacity of this well is a little less than 40 gallons a minute. An analysis of this. water published by the Belcher Hotel Company is as follows:

Analysis of water from the Belcher well, St. Louis, Mo.

[Parts per million.]

\begin{tabular}{|c|c|c|c|}
\hline Carbonate of & 9.4 & $\mathrm{NaCl}$. & $6,275.2$ \\
\hline $\mathrm{CaCO}_{3}$ & 189.8 & $\mathrm{SiO}_{2}$. & 2.4 \\
\hline $\mathrm{MgCO}_{3} \ldots$. & 18.2 & $\mathrm{H}_{2} \mathrm{~S} \ldots$ & 14. 1 \\
\hline $\mathrm{CaCl} . . . . . .$. & 496. 3 & $\mathrm{CO}_{2} \ldots \ldots \ldots$ & 55.2 \\
\hline $\mathrm{MgCl}$. & 684.6 & & \\
\hline $\mathrm{CaSO}_{4}$ - & 815.6 & & $8,721.6$ \\
\hline $\mathrm{KCl} \ldots$ & 160.8 & Total by direct determination. & $8,791$. \\
\hline
\end{tabular}

All wells reaching the St. Peter sandstone have found similar water. The formation increases in depth to the east and is reached at Mascoutah, Ill., 10 miles east of Belleville, at a depth of 3,069 feet. The water in this well, as in those farther west, is unfit for domestic use.

The capacity of deep wells in and near St. Louis, from whatever stratum their supply is derived, rarely exceeds 100 gallons a minute, and 40 gallons is considered a fair yield.

\section{FLOWING WELLS.}

The flowing wells of the area range in depth from less than 300 feet to more than 2,500 feet and in geologic horizon from the Osage group to the St. Peter sandstone. Flow from the Osage group is exemplified in a well at Edgemont, Ill., 782 feet deep, and probably also at the 
Keyes dairy farm, 2 miles east of Valley Park, Mo. A flowing well at Peters station 1,506 feet deep probably derives its water from Ordovician limestone. The same formation probably also yields a part of the water that issues from the deep well at Monks Mound.

Most of the flowing wells of the area tap the great reservoir of water in the St. Peter sandstone. Flows from this source are obtained by the wells at Monks Mound, Mascoutah, and Granite City, Ill., and the Belcher and other wells in St. Louis. In no well is the head sufficient to cause a very large flow. 



\section{INDEX.}

A.

Acknowledgments to those aiding.

Algonkian time, events in

Alton, Ill., coal at .

Ashburner, C. A., information possessed by...

Atkinson, C. W., well data of.

\section{B.}

Baden, cement plant at

$$
\text { clay near. }
$$

Ballwin, gravel near.

Bedford type of limestone, occurrence and character of.

Belcher well, Mo, record of . . . water of ........................6 67,68,69 analysis of.

Bellefontaine, limestone from

Belleville, Ill., section at......................

water supply of....................... 67

wells near............................ 68

Belleville coal, character of ........... 29-30,63-64

Bowman, Isaiah, on water resources........ 65

Brick clay, occurrence and character of..... 53-54

Broadhead, G. C., work of................... 16

Building sand, occurrence and character of. . $\quad 57$

Building stone, occurrence and character of.. 54-55

Burlington limestone, occurrence and character of....................... 20-21

water of

\section{C.}

Cahokia Mound, description of.

Cambrian time, conditions in

Cap au Gres sandstone. See St. Peter sandstone.

Carboniferous system, deposition of. occurrence and character of............ 19-30 water from........................ 67-68

Caseyville, Ill., coal near.................. 63

Castello, clay near...................... 52-53

Cement gravel, occurrence and character of.. $\quad 58$

Cement materials, occurrence and character of......................... 55-56

Centerville, Ill., coal near................... 63

Chain of Rocks, drift near.................

Cheltenham district, section in............. section in, coal in

topography in .......................

Cheltenham fire clay, deposition of ........... occurrence and character of ........ 28,50-51,52

Chester group, deposition of....... water from
"Coal Series," section of.....................

Collinsville, Ill. coal near. ................... section near. . . .

Creve Cœur Lake, fire clay at.............. $\quad 28$

Crystal City, sand at. . . . . . . . . . . . . . . $\quad 56$ section at, plate showing .............. 36

Crystal City sandstone. See St. Peter sandstone.

D.

Des Peres River, loess near............. $\quad 33$ sand at.............................. 57,58

valley of, character of ................. 10

Devonian time, conditions in ............. 39

Drainage, description of . . . . . . . . . . . . . 12-13

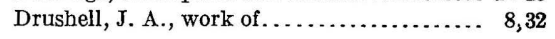

E.

East Alton, Ill., sand from........... 57-58

Economic geology, description of . . . . . . . . $49-69$

Edgemont, flood line near.............. $\quad 12$

flowing well at..................... 68

Edwardsville, Ill., drift near. . . . . . ...... $\quad 33$

Elevations, data on ................. 9,11

Elmwood Park, gravel near................ $\quad 31$

Eyerman's quarry, rocks of ............. 24

F.

Falling Spring, description of.............. $\quad 67$

Fern Glen, Mo., section at................. 19

Fern Glen limestone member, deposition of. . $\quad 40$ occurrence and character of ............ 20

Fire clay, mining of ...................... 49-51 occurrence and character of....... 49-51,52-53 uses of ............................ 51-52 See also Cheltenham fire clay.

First sandstone. See St. Peter sandstone. Flood plain. See Mississippi flood plain.

Floods, height of ...................... 11-12

Flowing wells, water of ...................... $68-69$

Fowke, Gerard, work of .................. 8

French Village, sand from ................ 57

Fruin-Bambrick Construction Co., well of, gas in....................... 61 


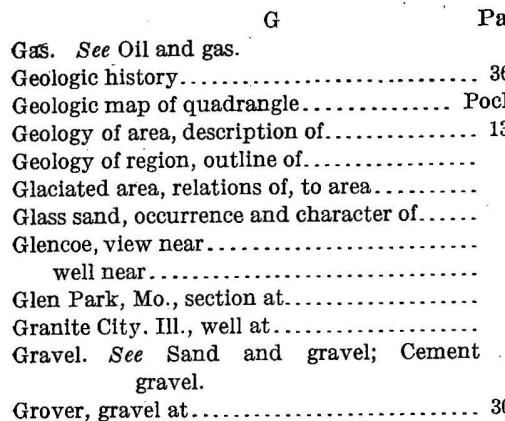

H.

Hambach, - , cited. well data from.

Hohn, Louis, "well data of............... 17

I.

Illinoian drift, deposition of. occurrence and character of. . ............. 32-33

Illinois, coal in . ..................... 63-64 cooperation of . . . . . . . . . .

Illinois Hydraulic Press Brick Co., well of, record of ................. 28

Insane Asylum, Mo., well near, section of. . 15-17, 18

$$
\text { J. }
$$

Jamieson-French mine, section at. . . . . . 25-26

Jefferson Barracks, drift near.............. 32

Joachim limestone, deposition of .......... 38 occurrence of...

Jones, J. C., work of.

\section{K.}

Kansan drift, deposition of .............. 46 occurrence and character of ........... 31-32

Kellar farm, oil well on................ 61 oil well on, section of . .............. 61 water from.................... 67

Keokuk limestone, occurrence and character of ...................... 20-21 water of .......................... 67

Keyes farm, wells at..................67,69

Kimmswick limestone, deposition of........ 38 occurrence of ..................... 18 water from ........................ 68

Kinderhook formation, deposition of....... $\quad 40$ occurrence and character of............ 19-20 water from . . . . . . . . . . . . . . . . . . . . $67-68$

Krümmel \& Büchner mine, section at........ 26

\section{L.}

Lafayette gravel, deposition of.. . . . . . . . 44-45 occurrence and character of use of.... view oi...

Lake water, character of.

Lime, limestone for, occurrence and character of...........................

Litton, A., work of .....................
Loess, deposition of................. $\begin{gathered}\text { Page. } \\ 46-47\end{gathered}$ occurrence and character of....... 30, 31, 33-34 view of....................... 30

\section{M.}

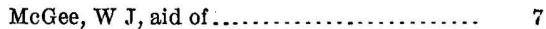
Magnesian limestones, deposition of......... 37-38 Malcolm, clay at..................... 53 Map, geologic, of quadrangle............. Pocket Map, index, showing area................ 8 Maquoketa shale, deposition of .......... $\quad 39$ occurrence of . ..................... 18

Mascoutah, well water at............ 67,68,69 Mentor, wells at.................... 67 Meramec group, occurrence and character of . 21-24 Meramec Highlands, Mo., rocks at, view of... 18 section near..................... $\quad 22$

Meramec Valley, loess in.............. $\quad 33$

Mississippi River, flood plain of, description of ...................... 11-12 oil wells in ................... 61-62

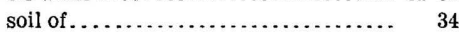
wells in ...................... 65 sand from ...................... 57

Mississippian saries, deposition of......... 40-42 occurrence and character of ............ 19-25

Mississippi trough, corrasion in .......... 48-49

Missouri, coal of ......................... . 64

Molder's sand, occurrence and character of... 57-58 Monks Mound, Ill., description of.......... 12 section at, plate showing ............. 36 well near, section of......... 14-15, 18, 25-26 water of . . . . . . . . . . 69

Mounds, occurrence and character of...... 12

N.

Nigger Hollow mine, coal from.......... 63-64

O.

Oil antd gas, occurrence of . . . . . . . . . . 58-62 prospects of . . . . . . . . . . . .

Ordovician system, deposition of . . . . . . . 38-39 occurrence and character of........... 18 water from . .................... 68, 69

Osage group, deposition of . . . . . . . . . . . . 40-41 occurrence and character of. ........... 20-21 water from . . . . . . . . . . . . . . . . 67,68

P.

Pacific, gravel near............... 30,31,44-45 rocks at, view of .................. 18 sand at......................... 56 section at, figures showing............ 36 Pacific sandstone. See St. Peter sandstone.

Pattonville, Mo., section near............ 26 Peneplain, occurrence of ................ 43-44 Pennsylvanian series, deposition of... . . . . 42-43 occurrence and character of . . . . . . . . 25-30 sandstones of..................... 28-29 use of .................... 55 water from ......................... 67

Peters, sand from.................... 57 section at, plate showing.............. $\quad 36$ wells at and near................. 62,67 
Plattin limestone, brine in............. Page. deposition of . .......................

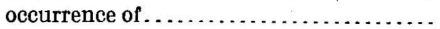

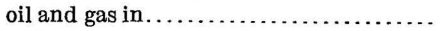

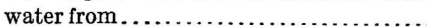
Pleistocene deposits, deposition in. . . . . . . 46-47 occurrence and character of.......... . . . 31-34

Post-Carboniferous time, events in . . . . . . . 43-44

Postglacial erosion, history of . ........... 48-49

Post-Pliocene time, events in ............. 45

Pre-Quaternary time, events in........... 45-46

Q.

Quarry rock, occurrence and character of.... 54-55 Quaternary system, occurrence and character

$$
\text { of...................... 31-34 }
$$

R.

Rankin, well at.

Recent deposits, occurrence and character of - 34-35

Rock terraces, location and character of......

\section{S.}

Saccharoidal sandstone. See St. Peter sandstone.

St. Louis, gravel near.

St. Louis and O'Fallon mine, coal from..... 63-64

St. Louis limestone, deposition of......... 41-42

occurrence and character of........... 23-24

views of $\ldots \ldots \ldots \ldots \ldots \ldots \ldots \ldots \ldots \ldots 24,30$

use of, for building............... 54-55

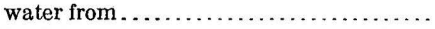

St. Louis Portland Cement Co., quarry of, sac-

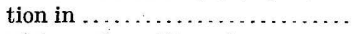

St. Peter sandstone, deposition of............ occurrence and character of ............

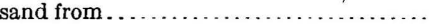

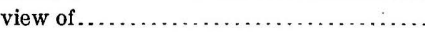
water from . ...................... 68,69

Salisbury, R. D., aid of................. 7 Sand and gravel, occurrence and character of. $56-58$ Sandstones, Pennsylvanian, occurrence and character of. . 28-29

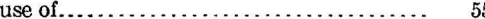

water from ....................... 67

Schoenberger Creek, course of............. 13

Schoolhouse Branch, sand from............ 57

Section, general, rocks in .............. 13-14

Sections, structure, plate showing ......... 36

Sections, well, details of .............. 14-17

Shale, occurrence and character of .......... 53

Shellenberger, well data of................ 15

Silurian-Devonian time, conditions during...
Page

ink holes, occurrence of .............. 10-11

view of ......................... 10

Spergen limestone, deposition of......... 40.41 occurrence and character of ........... 22-23

use of, for building.................. 54

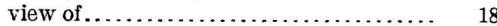

Springs, occurrence and character of....... 67

Stolle, Ill., loess near, view of............. $\quad 30$

sinkholes near, view of............... 10

Stratigraphy, description of................. 13-35

Stream water, character of................ 65

Structure, character of.................... $35-36$

relation of, to topography............. 10

sections showing, plate showing........ 36

Swallow, G. C., on coal measures . ...... . 26-27,29

T.

'Tamm's glue factory, well at, $\log$ of........ 60-61

Terraces, alluvial, occurrence and character

$$
\text { of.................... } 34-35
$$

See also Rock terraces.

Tertiary system, occurrence and character of. 30-31

Todd, J. E., cited ....................... 32

Topography, description of ............. 9-13 relation of, to structure ............... 10-11

U.

Ulrich, E. O., work of ................. $\quad 15$

Union Brewery, well at, oil in ............ 61

Upland, description of................ 9-11 wells on ....................... 66

V.

Valley Park, wells near............... 67,69

Valleys, smáll, location and character of .... 10

W.

Warsaw shale, deposition of . ............ 41 occurrence and character of. . . . . . . . . 21-22

Water resources, description of . . . . . . . $65-69$

Watkins Creek, drift near................ $\quad 32$

Webster Grove, gravel at................ 31

Welle-Boettler bakery, wells at, logs of...... . 59-60

Weller, Stuart, aid of.................. 7

Wells, deep, water of, analysis of .......... 68 source of........................... $67-69$

Wells, flowing, distribution and character of . 68-69

Wells, shallow, use of................... 65 water of . ......................65-66

Wheeler, H. A., cited.................... 32

Wisconsin time, events in .............. 47

Worthen, A. H., cited................. 32

Wright, G. F., cited................... 32 





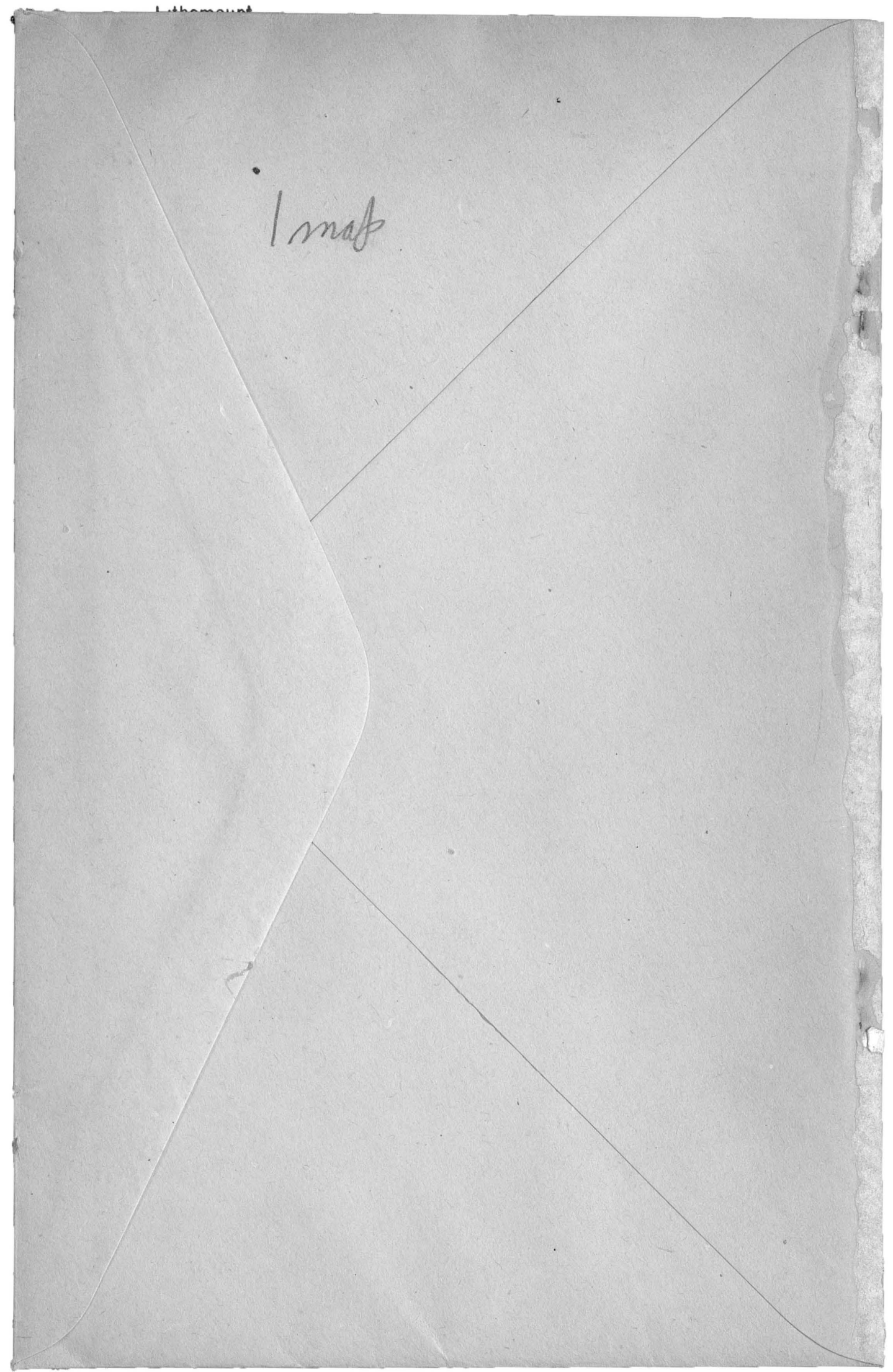


